Florida International University FIU Digital Commons

\title{
Factors That Differentiate Persistence Beyond The First Session At A For-Profit University
}

Jesus Fernandez

Florida International University, fern1091@bellsouth.net

DOI: $10.25148 /$ etd.FI1 1050314

Follow this and additional works at: https://digitalcommons.fiu.edu/etd

\section{Recommended Citation}

Fernandez, Jesus, "Factors That Differentiate Persistence Beyond The First Session At A For-Profit University" (2011). FIU Electronic Theses and Dissertations. 384.

https://digitalcommons.fiu.edu/etd/384

This work is brought to you for free and open access by the University Graduate School at FIU Digital Commons. It has been accepted for inclusion in FIU Electronic Theses and Dissertations by an authorized administrator of FIU Digital Commons. For more information, please contact dcc@fiu.edu. 
FLORIDA INTERNATIONAL UNIVERSITY

Miami, Florida

FACTORS THAT DIFFERENTIATE PERSISTENCE BEYOND THE FIRST SESSION AT A FOR-PROFIT UNIVERSITY

A dissertation submitted in partial fulfillment of the requirements for the degree of DOCTOR OF EDUCATION

in

ADULT EDUCATION AND HUMAN RESOURCE DEVELOPMENT

by

Jesús Fernández

2011 
To: Dean Delia C. Garcia

College of Education

This dissertation, written by Jesús Fernández, and entitled Factors That Differentiate Persistence Beyond the First Session at a For-profit University, having been approved in respect to style and intellectual content, is referred to you for judgment.

We have read this dissertation and recommend that it be approved.

Glenda D. Musoba

Tonette S. Rocco

A $\overline{\text { bbas Tashakkori, Co-Major Professor }}$

Thomas G. Reio, Jr., Co-Major Professor

Date of Defense: March 30, 2011

The dissertation of Jesús Fernández is approved.

Dean Delia C. Garcia

College of Education

Interim Dean Kevin O'Shea University Graduate School

Florida International University, 2011 
๑) Copyright 2011 by Jesús Fernández

All rights reserved. 


\section{ACKNOWLEDGMENTS}

Completing a dissertation while simultaneously engaged in a demanding job has been a difficult and challenging task. I could not have completed this personal and professional goal without the support and guidance of many. First, I wish to thank my committee chair, Dr. Thomas G. Reio, Jr., and my committee members Abbas Tashakkori, Tonette S. Rocco, and Glenda D. Musoba for their ongoing support, patience, and guidance throughout this project. I thank each of you for your assistance.

I also want to thank my fellow students who I have met during this journey. I am thankful for your support and friendship. Keep plugging away-you too will get there.

My colleagues at DeVry University who supported and assisted me, Donna Loraine, Julio Torres, Ruth Pacheco, Abour Cherif, Pat Mayers, Adiela Garcia, and Moyrali Roig, deserve special mention and acknowledgement. Finally, I want to thank my family and friends for their ongoing love, support, and encouragement. 
ABSTRACT OF THE DISSERTATION

FACTORS THAT DIFFERENTIATE PERSISTENCE BEYOND THE FIRST

SESSION AT A FOR-PROFIT UNIVERSITY

by

Jesús Fernández

Florida International University, 2011

Miami, Florida

Professor Abbas Tashakkori, Co-Major Professor

Professor Thomas G. Reio, Jr., Co-Major Professor

An increasing number of students are selecting for-profit universities to pursue their education (Snyder, Tan \& Hoffman, 2006). Despite this trend, little empirical research attention has focused on these institutions, and the literature that exists has been classified as rudimentary in nature (Tierney \& Hentschke, 2007).

The purpose of this study was to investigate the factors that differentiated students who persisted beyond the first session at a for-profit university. A mixed methods research design consisting of three strands was utilized. Utilizing the College student Inventory, student's self-reported perceptions of what their college experience would be like was collected during strand 1 . The second strand of the study utilized a survey design 
focusing on the beliefs that guided participants' decisions to attend college. Discriminant analysis was utilized to determine what factors differentiated students who persisted from those who did not. A purposeful sample and semi-structured interview guide was used during the third strand. Data from this strand were analyzed thematically. Students' self-reported dropout proneness, predicted academic difficulty, attitudes toward educators, sense of financial security, verbal confidence, gender and number of hours worked while enrolled in school differentiated students who persisted in their studies from those who dropped out.

Several themes emerged from the interview data collected. Participants noted that financial concerns, how they would balance the demands of college with the demands of their lives, and a lack of knowledge about how colleges operate were barriers to persistence faced by students. College staff and faculty support were reported to be the most significant supports reported by those interviewed. Implications for future research studies and practice are included in this study. 
TABLE OF CONTENTS

CHAPTER

PAGE

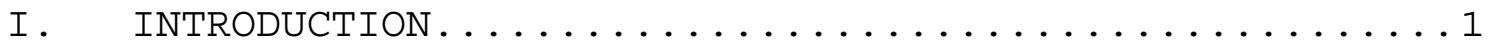

The Importance of a College Education ...........

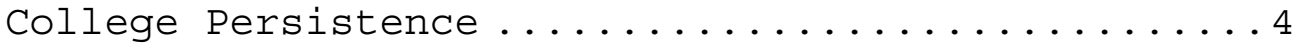

For-profit Colleges and Universities ...........

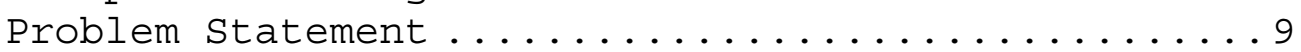

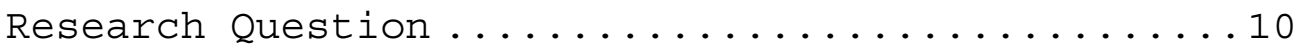

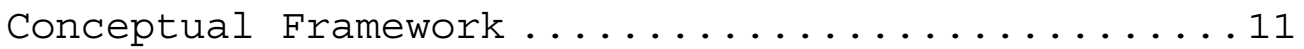

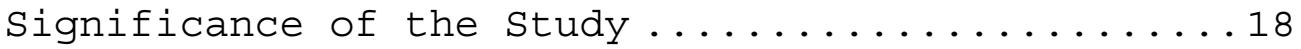

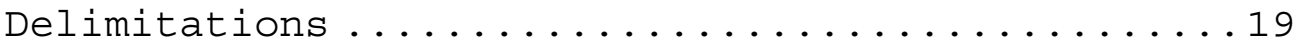

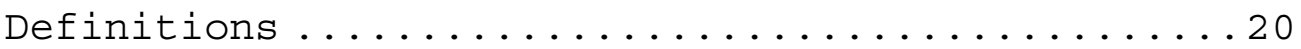

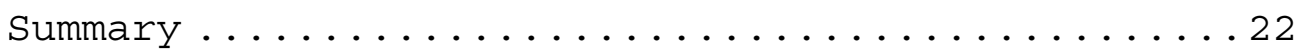

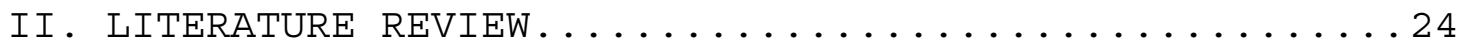

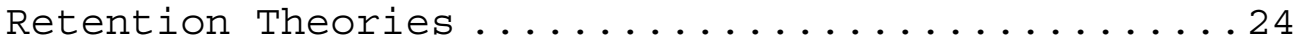

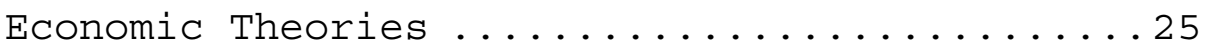

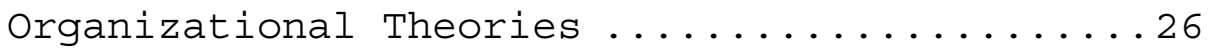

Psychological and Sociological Frameworks ...27

Empirical Research on Student Persistence...........35

Research on For-profit Institutions........35

Research on Factors Differentiating

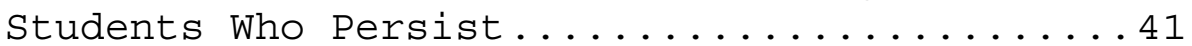

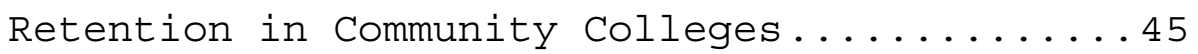

African American Student Persistence ............52

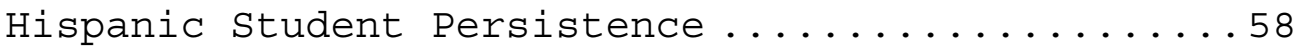

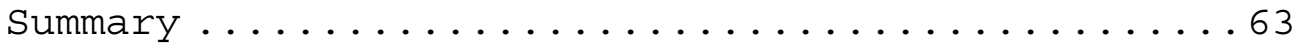

III. METHOD ...................... 66

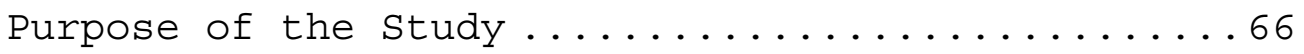

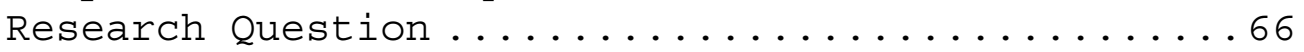

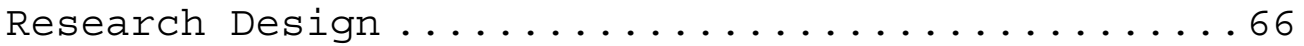

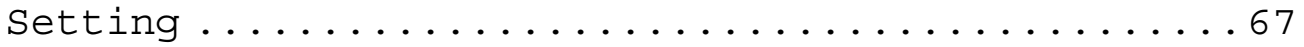

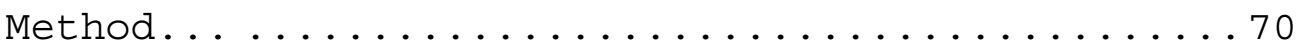

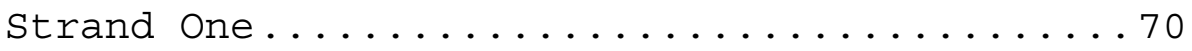

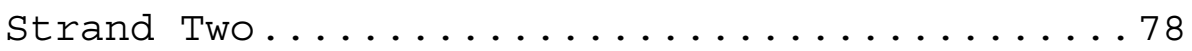

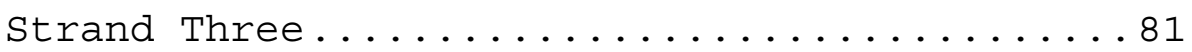

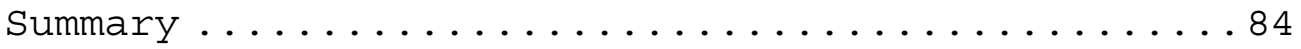

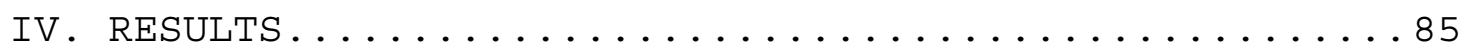

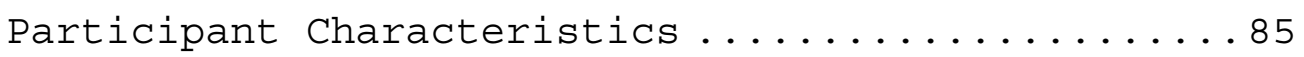

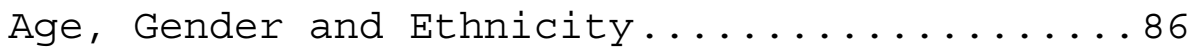

Degree Aspirations and High School GPA.....889

Parents' Educational Background...........91 
Expected Work Hours and Decision to Apply...993

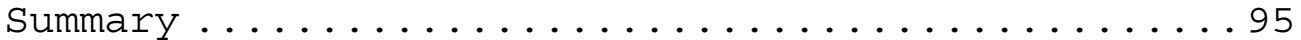

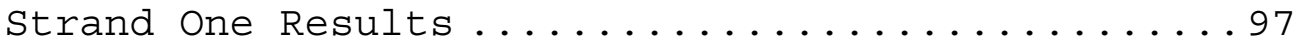

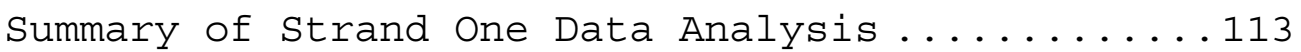

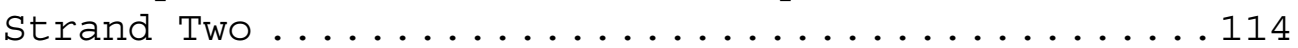

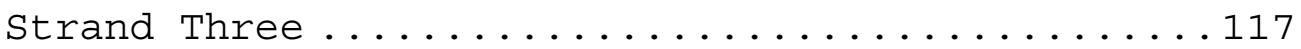

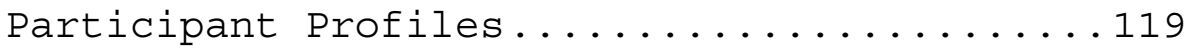

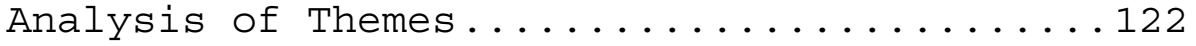

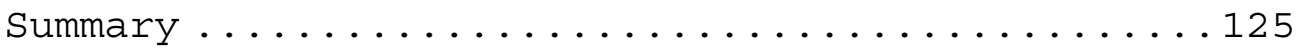

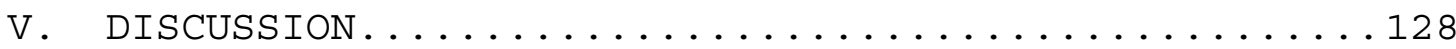

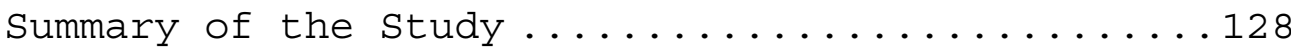

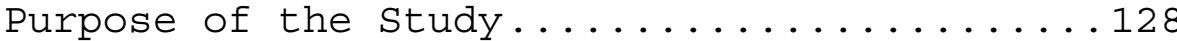

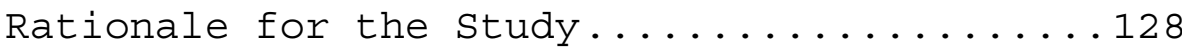

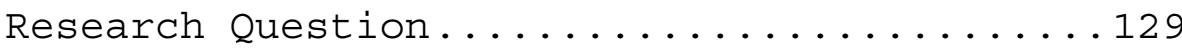

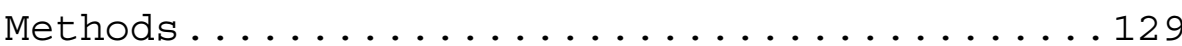

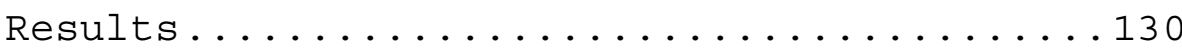

Recommendations for Future Research ..........132

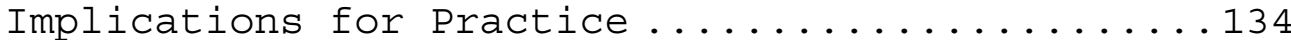

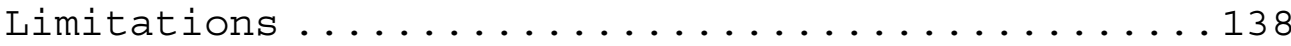

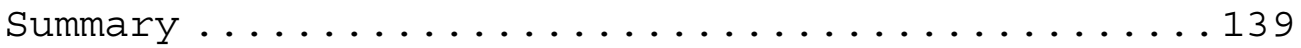

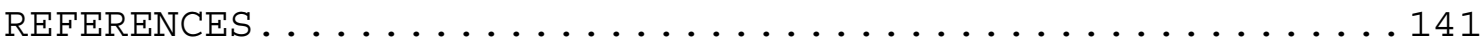

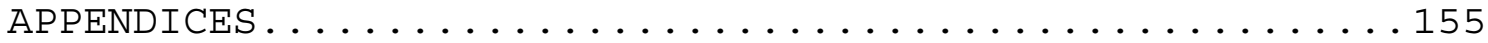

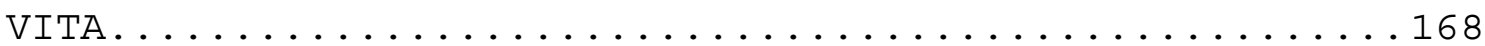




\section{LIST OF TABLES}

TABLE

PAGE

1. Demographic Information:

DeVry University South Florida ................ 71

2. Strand One Variables and Their Sources .......... 72

3. CSI Form B Domains and Scales.................75

4. Age, Race/Ethnicity and Gender of Participants... 88

5. Participants' Degree Aspirations and

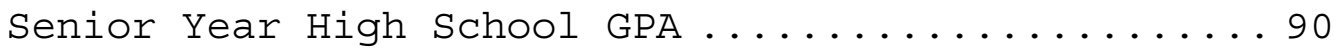

6. Parents' Educational Background ............. 92

7. Participants' Planned Employment ..............95

8. Summary of CSI-B Generated Scales .............99

9. Results of Factor Analysis ................. 102

10. CSI-B Scales Included in Factors ............. 103

11. Tests of Equality of Group Means ............ 107

12. Tests of Equality of Group Means ............. 109

13. Tests of Equality of Group Means ............. 111

14. Results of Factor Analysis .......................

15. Theory of Planned Behavior Questionnaire ........ 117

16. Summary of Participant Profiles............. 118 


\section{CHAPTER I}

\section{Introduction}

An increasing number of students are selecting forprofit colleges and universities (FPCU) to pursue or complete their education (Chung, 2008; Levesque et al., 2008; Oseguera \& Malagon, 2011; Phipps, Harrison \& Merisotis, 2000 Snyder, Tan \& Hoffman, 2006; Tierney \& Hentschke, 2007). Despite this trend, little empirical research attention has been paid to FPCU's and the students that enroll in for-profit institutions. The literature that exists has been characterized as rudimentary in nature (Chung, 2008; Oseguera \& Malagon, 2011; Tierney \& Hentschke, 2007). Studies focusing on retention and student behavior in for-profit institutions are limited in number and scope. The purpose of this study was to explore what specific factors are related to student persistence in forprofit colleges and universities. Specifically, this mixed method study investigated the factors that differentiated students who persisted beyond the first session at a regionally accredited, for-profit institution of higher education from those who do not. This chapter presents the background to the study by reviewing the importance of a college education, college persistence in for-profit 
colleges and universities. The conceptual framework, problem statement, and research question that guided this study are discussed next. The chapter concludes with an operational definition of terms, delimitations, and the significance of the study.

\section{The Importance of a College Education}

The positive impact that college has on students' well-being has been well documented in the literature (Bowen, 1977; Cohen \& Brawer, 2003; Merisotis, 2005; Pascarella \& Terenzini, 1991, 2005). Most published studies clearly support the view that consistent and positive cognitive, attitudinal, economic and psychosocial changes occur in students who attend college (Pascarella \& Terenzini, 1991, 2005).

For example, a study conducted by The Institute for Higher Education Policy (1998) reported that college improved the lives of those students who graduated in a number of ways including: (a) the quality of life for their families and offspring; (b) enjoyment of hobbies and leisure activities; (c) levels of savings; (d) personal and professional mobility; and (e) consumer decision making. Studies have also found that college graduates tend to be viewed as being open-minded, cultured, rational, 
consistent, and less authoritarian than individuals who did not attend or complete college (Pascarella \& Terenzini, 2005). Finally, graduation from college has been found to have a positive effect in decreasing prejudice and in enhancing social status as well as an individual's physical and psychological well-being (Cohn \& Geske, 1992).

In addition to these positive psychological and psychosocial changes, the impact of a college degree in providing a student access to higher paying jobs and careers is well established (Day \& Newburger, 2002; Shultz, Colton \& Colton, 2001). Individuals who are not college graduates often have low-paying, low-growth, and lowmobility manufacturing or service sector jobs (Pew Higher Education Roundtable, 1994). A college education has been found to be a critical factor for overcoming poverty and improving an individual's socioeconomic status (Swail, 2000; Swail, Redd \& Perna, 2003). Individuals who attain a bachelor's degree benefit from a $20 \%$ to $40 \%$ increase in earnings when compared to individuals who only complete high school (Pascarella \& Terenzini, 2005).

The average salary difference in 1993 between holders of bachelor degrees and high school graduates was calculated to be $\$ 15,201$ (Outtz, 1995). The magnitude of 
this difference has grown in successive years. A report released in 2006 by the U.S. Census Bureau states that the average salary of a bachelor's degree holder in 2004 was $\$ 51,554$ compared to the average salary of a high school graduate of $\$ 28,645$. Calculated over a 30-year career period, high school graduates earn approximately $\$ 1.2$ million; associate degree graduates earn $\$ 1.6$ million; and bachelor degree graduates earn approximately $\$ 2.1$ million.

The psychological and economic benefits that an individual accrues by graduating from college can be extrapolated to society as a whole. Researchers have noted a positive association between higher levels of societal education and better health, lower crime rates, greater levels of civic engagement and more vibrant national economies (Kelly \& Presott, 2007; Pascarella \& Terenzini, 2005). In addition, studies have documented the positive impact that college attendance has on increased tax revenues, greater workplace productivity, increased workforce flexibility and decreased reliance on government financial support (Pascarella \& Terenzini, 2005).

\section{College Persistence}

Given the positive effects reviewed in the prior section, why would a student leave college? Researchers 
have been struggling to answer this question for over 70 years and have noted that first-year attrition in particular is a longstanding problem (Braxton, 2000; Tinto, 1986). Increased calls for educational accountability by state and federal policymakers and student advocacy groups along with the increasing cost of a college education have sharpened the interest in college student persistence, both as a topic for scholarly research as well as for educational practice (Berger \& Braxton, 1998; Berger \& Lyon, 2005; Braxton, 2000; Braxton, 2009; Friedman \& Mandel, 2009). Prior research has shown that students who leave college often withdraw because of personal, social or financial issues (Horn \& Carroll, 1998; Pascarella \& Terenzini, 1995; Tinto, 1993). An analysis of the existing literature by Vincent Tinto has identified nine broad areas that can influence a student's decision to depart from college: (a) academic difficulty; (b) lack of adjustment to college life; (c) incongruent or changing goals; (d) uncertainty; (e) lack of commitment; (f) lack of finances; (g) integration and community membership; (h) incongruence with institution; and (i) isolation (Tinto, 2007). Although more students are entering college today, fewer are graduating (American College Testing Program 
[ACT], 2009). Persistence to graduation for all types of institutions was calculated at $45.0 \%$. Undergraduate persistence to graduation rates ranged from $28.3 \%$ at 2-year public institutions to $55.9 \%$ at private baccalaureate institutions (ACT, 2009). First to second year persistence for all colleges and universities during 2008 was calculated to be $65.9 \%$. Two-year public institutions had the lowest first to second year persistence with an average rate of $53.7 \%$, while private baccalaureate institutions had the highest at 68.9\% (ACT, 2009). Swail et al. (2003) estimated that $50 \%$ of all students who begin post-secondary education will eventually leave before completing their program of study. Finally, the majority of students who drop out of college leave within their first year of study and often during their first few months (Tinto, 1986). Early departure from college not only negatively impacts students who leave; it also negatively affects the colleges and universities involved. Braxton, Hirschy, and McClendon (2004) contend that the public and professional perception of institutional quality suffers when attrition is high. Similarly, the stability of institutional enrollments is negatively impacted by high attrition. In turn, this may negatively impact the budget of the 
institution resulting in additional disruption to the organizational climate.

\section{For-profit Colleges and Universities}

The educational marketplace has grown more complex as new providers including for-profit institutions have entered the arena, and established institutions (e.g., community colleges) have expanded their scope of operations. In $2006,2,679$ of the 6,536 post-secondary institutions in the United States were classified as forprofit institutions (National Center for Education Statistics [NCES], 2007). The major characteristics that for-profit institutions share have been identified by Kinser (2006). First, for-profit colleges and universities are not publicly supported by tax revenue, but rather by student tuition which, in turn, is often subsidized by government aid programs. For-profit institutions offer both undergraduate and graduate degrees, usually in careeroriented fields. A number of for-profit institutions are regionally accredited and must meet rigorous academic requirements. Most for-profit institutions are local and relatively small in size but some are national in scope and are part of larger, publicly traded corporate entities. Location housing for-profit institutions are much smaller 
than traditional colleges and universities and usually consist of classrooms, offices, and academic support services. The educational mission of for-profit institutions is focused on teaching and career-oriented education and does not typically involve research or academic scholarship (Tierney \& Hentschke, 2007). In 2003, for-profit institutions enrolled approximately $6 \%$ of the post-secondary student population and were the fastest growing segment of education institutions (NCES, 2007; Tierney \& Hentschke, 2007). Student enrollment at forprofit institutions grew 52\% between 1995 and 2000. By 2007, for-profit institutions enrolled over 2.5 million students or 9\% of all undergraduates in the United States (Fact Book, 2008).

Students who attend for-profit institutions are more likely to be members of a racial or ethnic minority group, are independent, are more likely to be first generation students, be academically unprepared, have parents who did not complete high school, report lower incomes than other students who attend traditional colleges and universities, and have had educational experiences that have not been successful or rewarding (Fact Book, 2008; Howard-Vital, 2006; Kelly, 2001; NCES, 2005). Minority students are 48\% 
of all enrolled students at for-profit institutions compared to $31 \%$ at public colleges (NCES, 2007; Tierney \& Hentschke, 2007). Students who come from families with incomes below $\$ 20,000$ are $27 \%$ of the population that enroll at for-profit schools compared to the $11 \%$ of students who report family incomes at this level and enroll in public institutions (Zamani-Gallaher, 2004).

\section{Problem Statement}

Persistence continues to be a significant issue for all colleges and universities (Berger \& Lyon, 2005; Braxton, 2000; Tinto, 1986). Despite decades of focus, persistence rates have remained stagnant (ACT, 2009). Growing numbers of students are selecting for-profit institutions to pursue their higher education goals (Chung, 2008; Oseguera \& Malagon, 2011). Although college student persistence has been studied empirically for years, few studies have examined persistence among students who attend for-profit colleges and universities (Chung, 2009). The studies that have focused on for-profit institutions seem to suggest that prior academic preparation, the quality of faculty interactions with students, students' commitment to completing their education, and their self-perceived efficacy about their academic skills are important factors 
that can help determine persistence. However, most of these studies have been marked by methodological weaknesses limiting their utility.

A need exists for research that focuses on the persistence of students who enroll in for-profit colleges and universities and the variables that distinguish between students that persist from those who drop out. Identifying those differentiating variables and factors can allow the institution to develop intervention strategies and programs aimed at enhancing student persistence.

\section{Research Question}

The main research question posed in this study was: What factors differentiate students who persist into their second session of study from those who drop out?

A mixed methods research design consisting of three strands was utilized. One strand covered students' selfreported perceptions of what their college experience expectations were. Their demographic information was collected during strand two. The third strand utilized a predominantly qualitative approach with a purposeful sample for maximal variation emerging from the results of the earlier strands. Semi-structured, funnel-sequenced interviews were utilized during this strand. 


\section{Conceptual Framework}

A number of theoretical and conceptual frameworks have been utilized by researchers to explain persistence in higher education including those that have focused on economic, psychological, sociological, and organizational factors (Braxton, 2000). Three theories-Tinto's student Integration Theory, Braxton's reformulation of Tinto's theory, and Ajzen's Theory of Planned Behavior-form the conceptual framework for this study. Collectively, these theories informed this study with factors that have proven to be important for explaining persistence in higher education.

Tinto's (1975, 1986, 1993) Student Integration Theory is the dominant theoretical perspective in retention research. Tinto argues that students' persistence in college is the result of a process where students assign values (either positive or negative) to their interactions with their chosen institution. These interactions occur with the people and the systems that make up every college and are influenced by the students' own characteristics.

The first step in the model is the pre-enrollment attributes that a student possesses and brings to college. These attributes include family background, academic skills 
and abilities, as well as any prior schooling history and experiences. These pre-enrollment attributes impact and influence the initial goals and commitments that students make to education and their chosen college. Once students enter school, experiences in the academic and social systems of their college begin to impact their decision to either persist or leave. Within the academic system, students' academic performance and their interactions with faculty and staff help shape their attitudes towards persistence. Experiences in the college's social system largely center on extracurricular activities and peer group interactions. Both types of interactions also shape students intent to persist. As these experiences accumulate, students either feel integrated into the college community or feel increasingly isolated. Individuals who feel connected will strengthen their goals and commitment to persist while those who feel isolated will likely question their goals, find their commitment to school waning, and possibly elect to drop out.

Tinto's theory has been tested empirically and has received varying degrees of support (Braxton, Sullivan \& Johnson, 1997). Criticism of Tinto's formulation have centered on two major fronts. First, the theory's roots 
have been challenged as not having applicability to college persistence. Tinto largely based his theory on Emile Durkheim's work on suicide. Durkheim (1951) felt that there were four types of suicide: fatalistic, egotistical, altruistic, and anomic. Of these four, Tinto believed that Durkheim's characterization of egotistical suicide was best able to explain student departure from college as it focused on behavior (suicide) that resulted when individuals are unable to become socially and intellectually integrated and establish membership within the communities of society (Tinto, 1993). Braxton and others have argued that linking college attrition and suicide is a stretch at best as for some people attrition may result in positive results whereas most consider the only outcome of suicide to be negative (Braxton et al., 1997).

A second and more robust line of criticism has centered on the limitations of Tinto's original studies. Opposing theorists have argued that Tinto's model is only applicable to traditional students, who were for the most part as 18-to 21-year-old White, middle class males who were full-time residents at their college. These critics have argued, and to a large extent, have shown that Tinto's 
theory is not very effective in explaining the attrition of non-traditional, minority, part-time or non-residential students who make up the majority of students today (Council for Adult and Experiential Learning [CAEL], 2000; NCES, 2002). Tinto's model is summarized graphically in Figure 1 .

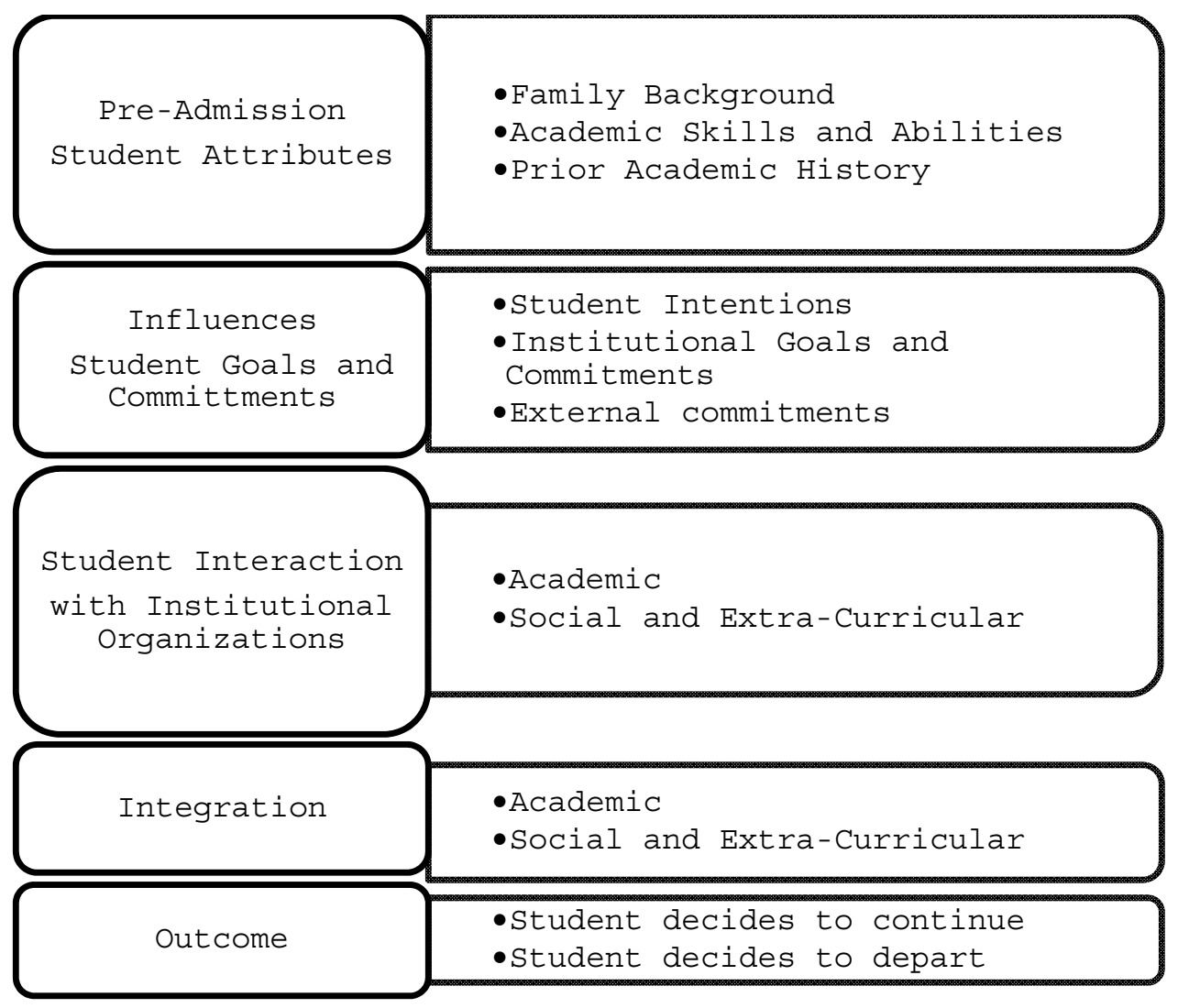

Figure 1. Tinto's Student Integration Theoretical Model (1993).

Incorporating the work of Bean and Metzner (1985), which focused on non-traditional and commuter students, Braxton and his associates have reformulated Tinto's original framework. Braxton's persistence framework 
addresses factors that non-traditional, minority, part-time and non-residential students encounter when making persistence decisions in college. When combined, these student groups comprise the majority of students enrolled at institutions of higher education today (Braxton et al., 2004; Braxton \& Lee, 2005) and the majority of students attending for-profit institutions (Tierney \& Hentschke, $2007)$

Braxton's reformulation also begins with the student's pre-existing attributes and characteristics. Braxton acknowledges more influence from the student's external environment while giving a student's academic experience equal weight with the traditional institutional factors favored by Tinto's original theory. This reflects the view that Braxton and his associates hold that non-traditional, minority, part-time and non-residential students have more external commitments and responsibilities and are more likely to only interact with the academic community during their class sessions. Braxton's model is summarized in Figure 2 . 


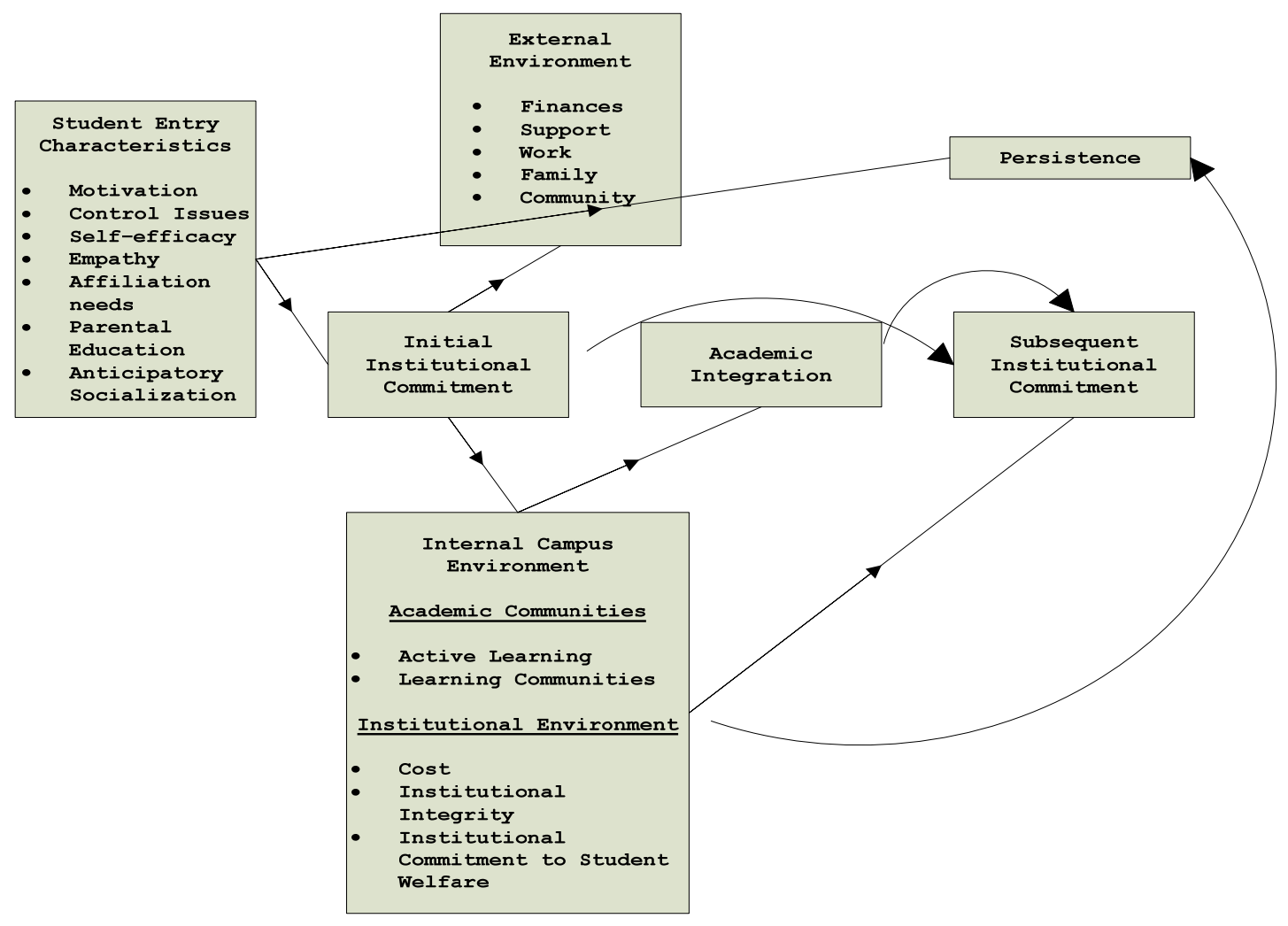

Figure 2. Braxton et al.s's Theory of Student Departure in Commuter Colleges and Universities (2004).

The final theory that formed the conceptual framework informing this study was the Theory of Planned Behavior (TPB) (Ajzen, 1991) and is summarized in Figure 3 TPB has been a useful tool for predicting a wide range of behaviors (Ajzen, 1991). TPB states that behavioral intentions are the main drivers of behavior. As rational beings, individuals make decisions about what to do on the basis of thoughtful reasoning. Intentions are determined by three variables or beliefs. The first determining variable, known 
as behavioral beliefs, focuses on the attitude toward the behavior in question by analyzing the potential outcomes of the behavior being contemplated and assigning positive or negative evaluations to the outcomes. The second type, labeled normative beliefs, looks at the subjective expectations of others and the motivation to comply with these expectations. The final belief type, labeled control beliefs, focuses on the factors that may encourage or prevent the performance of the intended behavior and the perceived power of these factors. If individuals feel that they have high behavioral control (i.e., they are not dependent on others to complete the behavior) then they will more likely complete the behavior in question (Ajzen, 2006). These three beliefs are influenced and modified by each other.

The intent to perform the behavior in question is determined by the three belief types. If the behavioral beliefs, attitudes toward the behavior, and normative beliefs are favorable and strong, and the perceived control is great, the person's intention to perform the behavior in question should be strong (Ajzen, 2006). Discordance between the behavioral and normative belief types lessens 
the likelihood that the individual will carry out and complete a planned behavior.

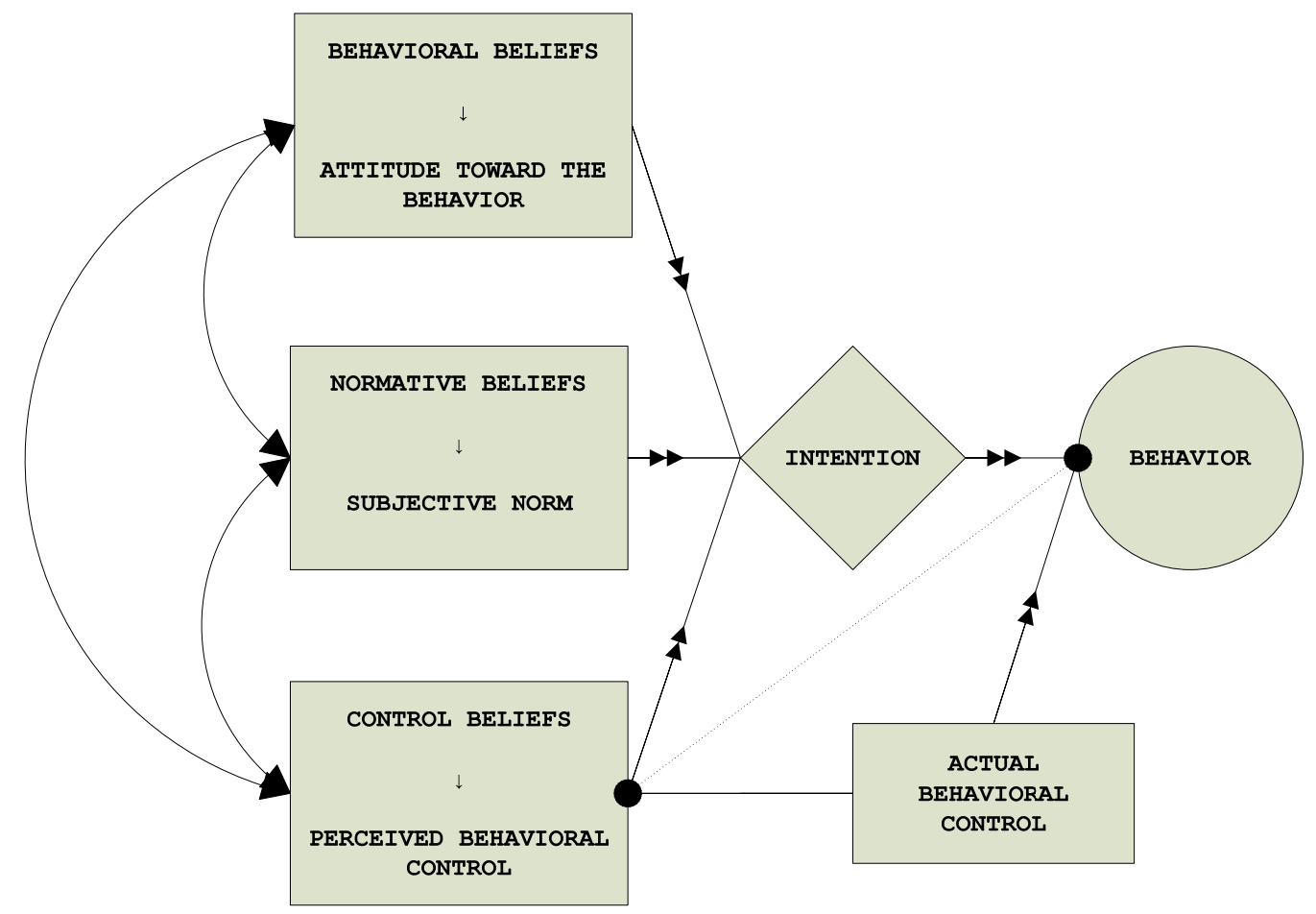

Figure 3. Ajzen's Theory of Planned Behavior (2006).

\section{Significance of the study}

There is growing concern today about student success and educational effectiveness (Kuh, Kinzie, Schuh \& Whitt, 2005). Although enrollments are at record levels, the ratio of students completing their programs of study and earning a degree has stayed constant for several decades. All stakeholders involved in the educational process, including state and federal governments, educational policymakers, students and parents, along with educational institutions are increasingly asking how many incoming students 
graduate. Increasing retention rates will have a significant positive impact for the individuals involved, for the institutions that they enroll in, and ultimately for society as a whole (Pascarella \& Terenzini, 2005). Knowing which factors differentiate students who persist from those who decide to drop out is the first step in improving student persistence and success.

The increasing differentiation of the educational marketplace and the introduction of new types of governance in higher education underscore the need for the extension and replication of existing research in different types of institutions, including for-profit institutions. Not only will this provide new information about how non-traditional (e.g., adult and commuter students) or under-represented (e.g., Hispanics, students of African descent) groups behave as they engage higher education; it will also allow researchers to expand, strengthen, and broaden existing theoretical constructs that delineate the field.

\section{Delimitations}

This study was limited by focusing on one location of a large for-profit university. The facility was located in Broward County, Florida, and is a majority/minority location with a limited number of non-Hispanic white 
students. Further replication of this study would be needed before the results could be extrapolated to other locations or institutions. A second limitation impacting this study was the use of self-reported data, and the instruments used to collect this data may not measure all of the variables that impact students' decisions to persist or drop out of college.

\section{Definitions}

For-profit institution. For-profit educational institutions are either organized as a corporation or sole proprietorship whose investors or stockholders benefit from a profit or suffer a loss as a result of the institution's educational services. A for-profit institution's main source of continuing funding is student tuition. While students are typically supported by state and federal government financial aid programs, there is no direct institutional support from the state or federal governments. Typically, forprofit institutions are blocked from obtaining research grants and thus concentrate on teaching and not research activities. The terms for-profit and proprietary are interchangeable and are equivalent in meaning . 
Non-traditional student. Non-traditional students are defined by The National Center for Education Statistics of the United States Department of Education (NCES, 2002) as any student who has at least one of the following characteristics: (a) did not enter post-secondary education in the same calendar year that he or she finished high school; (b) attends part-time for at least part of the academic year; (c) works more than 35 hours per week while enrolled; (d) is considered financially independent for purposes of determining eligibility for financial aid; (e) has dependents other than a spouse; (f) is a single parent; or (g) does not have a high school diploma. This definition was used in this study.

Student attrition. In this study student attrition is defined as the number of students who do not return to school after each session. The reasons for attrition can be either voluntary student choice or involuntary due to academic dismissal or other violations of institutional policies.

Student retention. Students who complete one session and enroll in the next subsequent session is the definition of student retention in this study. 
Stopping out. A behavior pattern where students leave school for one or several sessions and then return to enroll again in a later session.

Withdrawal. A voluntary departure from school by a student before completing all requirements for program completion.

Academic dismissal. An involuntary departure from school for not maintaining the institution's cumulative grade point average.

Attendance dismissal. An involuntary departure from school for not attending classes that a student is enrolled in over a 2-week consecutive time period.

Persistence. A student's uninterrupted part-time or fulltime registration until program graduation. Session. An 8-week term of study. Classes taught in sessions follow the established Carnegie hours of instruction. For example, a 3 -credit session course meets for 45 instructional hours spread out over an 8week period.

\section{Summary}

This dissertation investigated the difference between students who persist into a second session of study from those who drop out at a for-profit institution. This 
chapter provided an overview and introduction to the study along with a statement of the problem. In addition, the conceptual framework, research question, and the purpose of the study were also discussed. Chapter 2 reviews the relevant research related to this investigation. Chapter 3 describes the participants, measures, procedures, and data analysis that were utilized to answer the research question. Chapter 4 presents and discusses the findings that were obtained. Finally, using the findings, Chapter 5 presents conclusions and recommendations for both future research and practice in the field of student retention in higher education. 
CHAPTER II

\section{Literature Review}

The research question asked in this study was to identify factors that differentiated students who persisted into a second session of study from those who dropped out at a regionally accredited, for-profit university. In an effort to identify these factors, the existing research was reviewed. First, general theories underlying retention research are briefly discussed. Second, the empirical research on student persistence is reviewed. Studies that focused on for-profit institutions as well as community colleges were reviewed. Community colleges were included in the review as their educational mission is similar to forprofit institutions. Studies that have investigated the persistence of African-American, Hispanic, and nontraditional students were also reviewed as they are the largest student groups who attend for-profit colleges and universities (America loses ground in college access, participation, study finds, 2003, Chung, 2009; Tierney \& Hentschke, 2007 ).

\section{Retention Theories}

Scholars have studied college student persistence for over 70 years (Braxton, 2000; Tinto, 1993). The earliest 
studies on student persistence began in the 1930s (Berger \& Lyon, 2005). Studies that attempted to build a theoretical base that could be used to fuel future research began appearing in the 1970s. Theoretical approaches for student persistence can be categorized into four broad categories:
(a) economic theories,
(b) organizational theories, (c)

psychological theories, and (d) sociological theories. Each of these categories is briefly discussed in the following sections .

\section{Economic Theories}

Analyzing the costs and benefits of attending an institution of higher education by an individual forms the basis of the economic approach to college persistence. Economic theories stipulate that an individual's investment in education, training, or personal development should generate a return to the individual in terms of time, money, or energy. Braxton (2003) noted that departure from college might occur if a student perceives that the cost of attending a particular school exceeds the perceived benefits of attendance. A number of studies focusing on the relationship between financial aid and student persistence concluded that a student's ability to pay and their perceptions about the costs of their educational endeavors 
impacted retention (Cabrera \& Nora, \& Castenada, 1994; St. John, Cabrera, Nora, \& Asker, 2000).

\section{Organizational Theories}

The impact of organizational behavior on student persistence helps define the organizational theory framework. Bean (1980) adapted theories of worker turnover and argued that 10 variables influence student satisfaction, which in turn impact a student's decision to continue or leave school. Bean hypothesized that the following organizational variables could have a positive impact on student retention: participation, communication, and distributive justice. Routinization, another organizational behavior, had a negative impact on retention. Five individual level variables were also theorized to positively impact retention: grades, perceived practical value of coursework, personal development, course content, and membership in campus organizations. Over time, theories emphasizing economic and organizational factors have lost favor while those focusing on psychological and sociological characteristics have received increasing support and research attention. However, it is important to note that a student's socioeconomic status is still viewed as one of the strongest predictors of persistence. In 
addition, studies on the importance of financial aid and a student's ability to pay for college continue to appear in the research literature on a regular basis (Cabrera \& Nora, 1994; St. John et al., 2000).

\section{Psychological and Sociological Frameworks}

A growing number of theoretical formulations attempt to explain student attrition using psychological and sociological characteristics and processes. Psychological factors may include issues like academic aptitude and skills, motivational states, personality traits, and student development theories (Bean \& Eaton, 2000). The sociological perspective argues that social structures and social forces are the main drivers of college student attrition (Bean \& Metzner, 1985; Kuh \& Love, 2000). These theories argue that a student's peers, family socioeconomic situation (SES), anticipatory socialization, and the support of significant others are important factors that influence whether or not a student stays in school. Four authors' theories that utilize psychological and sociological factors-Astin (1984), Bean and Metzner (1985), Tinto (1975), and Braxton et al. (1997)-are reviewed in the following sections. 
Astin's theory of student involvement. Alexander Astin (1984) argues that a student's involvement in college directly correlates with the likelihood that the student will stay in school. Student involvement according to Astin is the physical and psychological energy that a student invests in the academic experience. A more involved student is likely to engage in behaviors that enhance his or her academic preparation and skills; is more likely to participate actively in extra-curricular activities, and will frequently engage with other students and faculty. An uninvolved student is seen as one who likely neglects his or her studies, is aloof about campus and college activities or lacks contact with peers or faculty. According to Astin, an involved student stands a better chance at staying in school.

Astin's theory consists of five basic tenets. First a student's involvement can be highly generalized (e.g., their entire experience as a sophomore) or very specific (e.g., preparing for their first mathematics midterm). Second, regardless of the experience, all involvement occurs along a continuum. Students can perceive the same experience quite differently, depending on the context. For example, a student may dread preparing for a mathematics 
midterm but enjoy preparing for a midterm in a psychology class. The third tenet explains that every experience has both qualitative and quantitative components. For example, the amount of time that a student spends studying for an exam can be measured quantitatively (e.g., how many hours are spent studying), and the student's experience can also be described qualitatively and quantitatively (e.g., the comprehension of the material exhibited by the student after studying). Fourth, the amount of student learning and development associated with any educational program is directly related to the quality and quantity of student involvement in that program. Finally, Astin asserts that the effectiveness of any educational policy or practice is directly related to the ability of that policy or practice to increase student involvement, which correlates with degree attainment.

\section{Bean and Metzner's nontraditional student attrition}

model. Bean and Metzner (1985) proposed a retention model that focused on the older, non-traditional student. They suggest that student persistence is guided by one or a combination of the following variables: (a) academic performance, (b) intent to leave, (c) previous performance and educational goals, and (d) environmental variables. 
Bean and Metzner contend that environmental variables, including finances, hours of employment, outside support and family responsibilities, are more important in determining whether an adult student persists than academic performance. The researchers claim that environmental variables are so salient to adult learners that they can compensate for weak academic support. Finally, the authors also claim that the most important environmental variables (e.g., finances, family responsibilities, and number of hours worked while in school) are likely to differ for subgroups such as part-time students, minorities, academically under-prepared students, and those individuals who are enrolled in non-traditional colleges and universities.

Tinto's student integration theory. Spady (1970) took a sociological approach and theorized that attrition was explained by the interaction of a student's attributes and the college environment. If there is congruency or fit between the student and the collegiate environment, the student feels welcome and at ease both socially and academically, thus heightening the likelihood that they complete their educational pursuits. A lack of congruency 
or fit increases the possibility that the student will abandon their goals and leave school prematurely.

Building on Spady's work and Durkheim's theory of suicide (1951), Tinto (1975, 1986, 1993) argues that student departure from college is the result of a longitudinal process where a student assigns meaning to his or her interaction with all aspects of their chosen college or university. Specifically, Tinto states that three characteristics (family background, academic skills, and prior academic experiences) that each student possesses when they enter college directly influence their decisions to either stay in school or depart. Two additional factors influence student persistence. One is the students' initial commitment to the institution, and the second is the student's commitment to the goal of graduating from college. These two factors influence the level of a student's potential integration into the academic and social environment provided by their institution.

An institution's academic environment helps students enhance their commitment to the institution and their eventual graduation through either structural or normative methods. Structural academic integration calls for the student to meet the explicit academic standards of the 
institution. Normative integration comes about when a student identifies with the normative structure of the institution's academic system.

Social integration also helps fuel a student's commitment. Tinto contends that social integration exists when there is congruency between the individual student and the social system of a college. A college's social system is composed of individuals within the college, informal, and formal organizations as well as the entire college community.

A student's individual entry characteristics along with their social and academic integration form an iterative cycle with the student's commitment to the institution and to graduation. The greater a student's academic integration, the greater the student's level of commitment to the goal of college graduation. The greater a student's social interaction, the greater the likelihood that the student's commitment to the institution will increase. The higher these commitments go, the higher the likelihood that the student will persist. Subsequent revisions of Tinto's model (Braxton, 2003; Pascarella \& Chapman, 1983) have added and incorporated additional influencers on student commitments including financial 
resources, family and work support, and a student's classroom experience. This elaboration is discussed in more detail in the following section.

\section{Braxton's theory of student departure from commuter}

colleges and universities. Braxton et al. (1997) noted that few of Tinto's theoretical constructs have been supported by studies conducted in commuter colleges and universities. Based on findings from the literature, Braxton and his associates used an inductive approach to develop their extension of Tinto's earlier work. In their work with nontraditional students, Bean and Metzner (1985) observed that different types of students attend commuter schools from those who attend traditional residential institutions. Students at these institutions can include traditional age students who live at home with their parents, older students who may or may not be in the workforce, students with family obligations, full-time students and part-time students. Thus, for many students who attend commuter or non-traditional institutions, their academic endeavors are among the various activities that fill their lives.

According to Braxton et al.'s model, eight factors influence student persistence at commuter schools. First, a student's entry characteristics influence persistence. 
Examples of these characteristics include a student's family background, academic ability, academic preparation, and gender. Second, the external environment can impact student persistence. The internal campus environment impacts whether a student connects or disengages and eventually leaves school. Braxton and his associates also claim that a student's psychological and sociological characteristics influence their decision to persist in school. Organizational (e.g., student services) and economic factors (e.g., financial aid) also influence student retention. Finally, Braxton argues that without strong social connections on campus, commuter students are even more impacted by the academic community available to them. They argue that in a commuter school, the classroom must serve as a community, forging meaningful connections between students and faculty and among students themselves. This refinement and extension of Tinto's earlier work by Braxton and his associates is relevant to the current study in that it takes into account factors that might impact student persistence among non-traditional students. No one theoretical model focuses on the specific correlates of persistence in for-profit universities. No theoretical framework explains or predicts persistence in a 
for-profit setting. Each of the models and theories reviewed can contribute to the development of a model that is highly relevant to these institutions. Clearly, any persistence model needs to incorporate economic components, an individual's psychological characteristics, institutional, and organizational factors.

\section{Empirical Research on Student Persistence}

\section{Research on For-profit Institutions}

For-profit institutions of higher education are generally not well represented in the research literature (Ruch, 2001; Tierney \& Hentschke, 2007). The majority of published studies on for-profit colleges and universities have focused on organizational and economic structure. Few studies have concentrated on student behavior or their academic experiences in these institutions.

Sauchuk (2003) postulated that due to the pressure generated by shareholders and other external parties many for-profit institutions dedicate substantial efforts and resources to improving student persistence. He theorized that this environment could be a fertile source for proven effective strategies that could be used to enhance retention throughout the educational spectrum. In order to investigate this, he conducted a case study of retention at 
the Art Institute of Philadelphia. Two programs were selected for the study: photography and industrial design technology. The photography program had the lowest graduation rates within the institution while the industrial design technology program enjoyed the highest graduation rate. Sauchuk had several research questions (a) why did the industrial design program retain their students at a higher rate? (b) What roles do administrators, faculty and students play in retention at a for-profit college? (c) Does the type of academic program a student enrolls in impact retention? and (d) How do student entry variables impact retention at a for-profit college?

Several methods were utilized in the study. First, college documents were reviewed and examined. Information including student demographic data, program characteristics, class attendance, and completion records as well as internal college retention reports was collected. Second, the investigator observed and took notes at college staff meetings where retention was discussed. Third, semi-structured interviews were conducted with 10 administrators, 20 faculty members, and 30 randomly selected students. Finally, graduation rates, student GPAs, and remedial class participation classes were examined. 
Sauchuk (2003) concluded that three major factors caused the differences in retention rates between the two programs. First, prior academic preparation was identified as a strong predictor of retention at this institution. Students who had strong backgrounds in both math and English were more likely to graduate than those students who needed remedial assistance. Second, positive relationships between students and faculty played an important role in integrating students into the institution and this impacted retention rates favorably. Finally, employment criteria directly impacted retention rates. Students who matriculated in the industrial design technology needed to complete the degree to qualify for job openings in the area. Few positions were available for applicants who had not completed a post-secondary degree. The photography program did not benefit from this situation as students were able to exit the program and enter the job market successfully without completing the program.

Boggs (2007) conducted a study investigating the differences between students who maintained continuous enrollment in college from those that did not. Demographic variables, entrance exam scores and the student's college transcript were analyzed in this ex post facto study. A 
regression analysis showed that the number of credits taken during a student's third term of study was the only predictor that a student would stop enrolling. Students who enrolled for 12 credits or more were more likely to persist than those students who enrolled for 6 or fewer credits.

Dyer (2006) studied persistence at a group of 25 forprofit art and design colleges by analyzing internal documents detailing persistence data for each of the colleges. Each college's enrollment was broken down by gender, race, and program of study and recorded. A questionnaire was also developed and completed by administrators at each college. The questionnaire was aimed at determining the level of implementation of 19 student success practices adopted by the group. Data from the internal documents, demographic breakdown, and the questionnaire were entered into a stepwise regression equation. Race was the only factor found to be a statistically significant predictor of persistence $(p=$ .02) with White students more likely to persist at these institutions than non-White students. Race was found to account for $46 \%$ of variance. No other variables were found to be statistically significant. 
Baughman (1997) investigated students who graduated from a for-profit institution. The study attempted to determine if a student's feeling of self-efficacy or demographic variables as well as the student's academic performance during their first session of study predicted eventual graduation. Students who reported high levels of self-efficacy were found to be more likely to complete their program of study than those who had low or middle feelings of self-efficacy.

Piazza (1996) studied 742 students at a proprietary post-secondary institution in Georgia. The purpose of the study was to investigate the applicability of Tinto's (1986) model of voluntary student withdrawal. The study was the first attempt to establish the validity of Tinto's theory in a for-profit institution. Students were surveyed twice using a questionnaire developed by the investigator. The first survey was completed at the beginning of the first session and the follow up survey was administered during the second session or by mail if the student had left the institution. Of the 742 students in the research pool, 318 completed the first survey with 204 completing both surveys. The resulting data suggested that a student's commitment to achieving his or her goal of earning a 
college degree was the strongest influence predictor of persistence. The results also supported the hypothesis that faculty interaction with students had a positive influence on retention. Certain demographic factors (age and gender) were found to be positive forces impacting retention. However, race was not found to be a significant contributing factor in students' decision to persist.

Clehouse (2000) conducted a study whose purpose was to create and pilot a predictive instrument to measure student persistence at DeVry University-Chicago. The researcher selected six valid and reliable pre-dispositional survey instruments from the literature and combined them to form one instrument. The resulting 100-item questionnaire was administered to 925 first term, first year students at two DeVry locations in the greater Chicago area. In this study persistence was defined as those students who were still enrolled one year after their initial term. Data analysis consisted of direct discriminant analysis with further analysis using ANOVAs and $t$ tests. Of the original nine constructs measured by the combined instrument, seven were found to be significant $(p<.05)$. Locus of control was discovered to the best predictor for those students who were considered to be academically prepared for college 
based on admission scores on the College Placement Test (CPT) published by the College Board. Coping skills and the expectation-disconfirmation quality were found to be the best predictors for students who needed to complete developmental coursework before beginning college courses. The studies reviewed above that have focused on persistence within for-profit institutions have methodological weaknesses that limit their utility. The combined information generated by the studies does not adequately explain the factors that differentiate students who persist from those who drop out at these institutions. For example, Sauchuk's (2003) study is hampered by a small ( $\mathrm{n}=30)$ student sample. Piazza's (1996) study used a selfdeveloped research questionnaire without assessing its reliability and validity. Finally, Clehouse's (2000) research study suffers from a fragmented theoretical framework that is not grounded in prior research on college student persistence (e.g., Tinto's student Integration Model; Bean and Metzner's Nontraditional student Attrition Model) .

\section{Research on Factors Differentiating Students Who Persist Most of the available research on pre-enrollment predictors of attrition have centered on cognitive measures}


including SAT and ACT scores (Moore, Jensen, Hsu, \& Hatch, 2002). The majority of published studies report that student scores on cognitive tests like the SAT and ACT do not predict student persistence in college (Arbonna and Novy, 1990). Moore (2004) suggests that this weak correlation may be attributed to the fact that such tests allegedly measure a student's cognitive ability but that they do not measure non-cognitive factors such as motivation which has proven to be critical to success in academic endeavors.

In a study using data from the Cooperative Institutional Research Program (CIRP) freshman survey, investigators studied 5,221 students to identify predictors of retention. Sixty two variables were examined in a logistic regression model, resulting in 16 that, according to the researchers, were effective predictors of persistence. These factors included but were not limited to the numbers of hours that students worked during their studies; fears about their ability to pay for school; their perceived relationships with their high school teachers; their expectations of academic problems that they would encounter; and their parents' educational history. 
In a study largely aimed at assessing the predictive validity of the Risk and Promise Profile, Cubeta, Travers, and Scheckley (2000) studied 542 students attending six different educational institutions. The investigators found that successful students tended to be older than those students who were not successful. In addition, successful students reported that their prior experiences in the educational system were positive as opposed to those students who were not successful in their earlier educational pursuits. Successful students were also found to have higher levels of academic self-efficacy as learners, an internal locus of control, and a strong motivation to succeed.

McDaniel and Graham (2001) reviewed persistence at a historically Black university. The sample consisted of 1,949 first time degree seeking students. The predictor variables that had the highest correlations with one year retention statistics were overall ACT test scores, ACT math sub score, adequacy of prior education, high school grade point average, high school rank, and the students' views of themselves.

In another study using the College student Inventory, Browning (2000) followed a cohort of 474 college students 
for 2 years. Students initially completed the CSI and then were monitored 2 years later to see if they were still enrolled. The study found that students who had a high level of self-perceived leadership ability, a high level of self-perceived emotional support from their families, and a high sense of career knowledge were more likely to persist than those who did not.

Allen (1997) examined the relationship between entry variables as well as three motivational factors on retention and grades of 81 college freshmen. The entry variables were gender, ethnicity, parental education, financial aid status, and high school rank. The motivational factors were identified from the Noel Levitz College student Inventory (CSI) and included: (a) desire to finish college, (b) the impression of the institution, and (c) family emotional support. The investigator concluded that a student's motivation as measured by the CSI was a positive predictor of persistence. Students with low scores on these scales tended to have significantly higher attrition than those students who reported strong motivation. 


\section{Retention in Community Colleges}

Community colleges are highly similar to for-profit institutions in terms of program offerings and student characteristics. Most community colleges focus on career or technical education which is the niche where most if not all for-profit institutions operate. Also, most community college campuses have limits with respect to student services and social activities as most cater to adult, first time in college commuter students. For-profit institutions tend to target the same type of students for admission. Instructional processes and resources are similar in both types of institutions as both focus on teaching activities as opposed to research. Finally, the research on African American and Hispanics that deals with retention is also relevant as they tend to most likely be first time in college students. These students are typically targeted for recruitment by the for-profit institutions.

McClenney and Waiwaiole (2005) reported six strategies that had been found to be successful in mitigating student attrition at a dozen "best practice community colleges." The colleges were designated "best practice" as a result of a review of their performance on the Community College 
Survey of Student Engagement (CCSSE) along with an analysis of their institutional retention data and a blind review of their retention practices by a national panel of community college experts. The following strategies were found to be exemplary: (a) Use of student success courses; (b) Use of learning communities; (c) Effective advising; (d) Collective responsibility for retention; (e) Extensive use of learning support strategies, and (f) Hiring the right people.

Many if not most community colleges operate under the premise of open admissions. Freer-Weiss (2004) investigated the concept of late admission and the impact of this process on student attrition. The investigator reviewed 785 admissions files of first time matriculated college freshmen. Using Tinto's model of attrition (Tinto, 1986) as a theoretical base, the investigator hypothesized and confirmed that students who applied late had different characteristics than students who applied earlier. A second hypothesis was that students who apply late to college did not perform as well academically as students who did not apply late. The findings did not support the second hypothesis in that late applicants did not significantly differ in academic performance from those students who had 
applied earlier. A final hypothesis that was tested and supported was that students who applied late were less likely to re-enroll in college during a subsequent term. This study found that students who apply late have different demographic characteristics, prior academic histories, and enrollment objectives than those students who applied to college earlier. The author concludes that the profile of the late applicant in this study strongly supports the profile established in the literature for students with the highest attrition rates.

Zhai and Monzon (2001) studied students who had dropped out of one of three community colleges in the san Diego Community College district. Information was collected from student records. A questionnaire was sent to random samples of students to assess their reasons for leaving. Significant reasons reported by students as reasons for their departure included class and work schedule conflicts, financial difficulties, and a lack of financial aid.

Moman (2002) studied the effects of a mentoring intervention on student retention in a community college in Indiana. The study investigated the effects of mentoring along with variables such as gender, ethnicity, marital status, and age group on student retention and grade point 
average. Results indicated that females responded favorably to mentoring and therefore had higher grade point averages than males did. In addition, the data supported the notion that older students were more likely to persist than younger students.

Solis (1995) studied the intent to persist among 100 community college students in five Texas institutions. The students completed a questionnaire on their college experiences, out of college support systems, financial ability to complete college, and intent to persist. The advisement that students received was a critical factor that impacted students' intent to persist. This was especially true for Hispanic students.

Hawley and Harris (2005) studied entering students at Prince George Community College. Students in the study were given the Cooperative Institutional Research Program Freshmen Survey to complete during an orientation session. Factor analyses of the student responses suggested that characteristics predicting student persistence were clustered around three major areas: barriers, motivation and aspirations, and expectations. Specifically, the number of developmental classes required to be completed (barriers), the intention to transfer to a 4 -year 
institution (motivation and aspirations), and the expectation that English as a second language could be problematic were the strongest predictors of attrition. Dayton (2005) interviewed 22 community college students with a focus on identifying what forces created challenges for them to stay in school. She noted six major challenges that students identified as forces to overcome if they were going to succeed educationally. First, students identified financial difficulties as a source of considerable concern. Second, poor communication skill in the English language was mentioned by students as a key factor contributing to their fears. Motivation was mentioned by all students as a challenge to overcome. The remaining forces identified in the interviews were transportation, balancing school and work, and limited resources available at their respective community college.

Membership and participation in a supportive community was found by Naretto (1995) to be of critical importance for adult students in community colleges. Adult students who persisted indicated greater positive involvement and connections with both student and faculty communities than those who did not complete their degrees. This finding was supported by a study conducted by Graham and Gisi (2000). 
They analyzed the responses of 19,000 students who had completed the College Outcomes Survey published by the American College Testing Program (2009). Their findings showed that the more time adults were engaged in academic experiences, the greater their self-reported learning outcomes. The researchers also concluded that interactions that students had with their faculty members were an even stronger predictor of student success and satisfaction with their respective learning experiences.

Guarino and Hocevar (2005) surveyed 641 community college students in introductory psychology classes. Student's locus of control, commitment, and social and academic integration were measured. The investigators discovered that students with an internal locus of control were $40 \%$ more likely to persist but achieved lower grades than those students with an external locus of control. Additional findings of interest reported in this study were that female students were twice as likely to drop out as male students and minority students were 1.5 times more likely to drop out than non-minority students.

Ulm (2002) investigated the effect of a mentoring intervention on student persistence at Ivy Tech state College in Indiana. Participants included students who were 
identified as having a high dropout potential after completing the College Student Inventory (CSI). The effect of mentoring and selected demographic variables on student retention and grade point average was studied. The results revealed that the interaction of gender and mentoring treatment were significant on grade point average (minimum increase of .25). Age had positive effects on both retention and grade point average. The dropout proneness score generated by the CSI could not predict either retention or grade point average with this sample.

Basha and Lunenburg (2001) assessed the usefulness of the College student Inventory (CSI) as a predictive tool by researching which, if any, of the 17 scales of the CSI distinguished enrollment status and academic success in students attending community colleges. The research sample consisted of 1,368 students at eight community colleges. Significant differences were found for 2 of the $19(\alpha=$ .05) scales of the full version CSI. The Academic Assistance scale differentiated between students who persisted from those that did not. The Career Counseling scale successfully distinguished between academically successful and academically unsuccessful students. 


\section{African American Student Persistence}

A number of studies have investigated African

Americans who persisted and sought to identify those characteristics that made them successful in college. A number of operational definitions of success and persistence can be found in these studies, which have mostly focused on the completion of the first year of study and then graduation. Mason (1998) reported that the extent to which African American students were likely to persist in their studies depended on how clear they were about what they wanted to be, or achieve, and on how deep seated these goals were. Mason interviewed 93 African American males who attended the City Colleges of Chicago. In addition to their desires, students reported that the support that they had received from outside the college and the extent to which they believed that their educational pursuits would benefit their future were factors that impacted their persistence. It is important to note that these were student perceptions and should not be perceived as a causal statement.

Allen (1997) reported that African American students who engaged in social activities reported that they were a part of the institutional social environment and were more likely to persist than those students who did not engage 
and remained isolated. These findings were replicated by Watson and Kuh (1996) and Berger and Milem (1999). Peltier, Laden, and Matranga (1999) reported that African American women persist at a higher rate than African American males. According to Trippi and Baker (1989), social integration significantly contributed to the persistence of African American females but not African American males.

Sleet (2000) interviewed African American undergraduates and found that those who were successful and completed were able to establish and engage support systems that helped them cope with the challenges presented by their studies. In addition, the researcher noted that successful African American students had an internal locus of control, as they took personal responsibility for their education and did not delegate this to others. Littleton (2001) studied African American students who persisted at predominantly white small colleges in Appalachia. The researcher was able to synthesize several common themes. African American students that persisted reported that faculty influence, campus involvement, support from family, peer relationships, and a positive attitude as important factors that led to their persistence. 
Several studies have specifically focused on identifying factors that differentiate African Americans who persist into a second session of study from those who did not. In a study of 202 degree seeking community college African American male students, Serra Hagedorn, Maxwell and Hampton (2002) attempted to identify factors that could best predict retention among this student cohort, which traditionally has the lowest retention rate of all racial or ethnic groups nationally. Placement data that assessed a student's basic writing, reading, and math skills were collected on each student. In addition, student's selfreported feelings on their educational background, college plans, plan of study, work responsibilities, high school coursework, and their efficacy in English and mathematics were collected. Logistic regression was utilized to analyze the data. Four variable groupings were used in the regression equations that were designed. The first grouping was labeled demographic and high school experience and consisted of the participants age, their parents' level of education, the number of years they had studied English in high school, their high school GPA, the highest level of mathematics that they had taken, and the number of years that they had studied science in high school. The second 
grouping included placement test results as well as selfefficacy ratings of academic ability. The third grouping contained students' self-reported perceptions about experiences that occurred during their first session. The experiences were whether or not they attended an orientation session, the number of credit hours they attempted, the number of credit hours that they completed, whether or not the student planned to attend classes during the day, whether or not the student was in a vocational program, the students certainty of their chosen major, number of hours spent studying, whether or not the student had a prior college degree, and their GPA for the first session. The fourth grouping included the number of hours that each student worked, the student's perception about the importance of completing college, the number of hours the student spent relaxing and the student's self-reported need for academic assistance.

Of the 202 African American males who began college, 75 or $36.9 \%$ returned for a second session. Variable blocks one (factors related to a student's high school experience and demographics) and three (factors related to a student's school experiences during their first session) were reported to explain a large and significant proportion of 
the dependent variable (retention) variance. Several individual predictors also proved to be significant predictors of retention between session one and two. First, being younger proved to be positively linked to retention. This finding is not consistent with other studies (Pascarella, Smart \& Ethington, 1986) which found no correlation between age and retention for African American students. A second individual predictor, the number of enrolled credit hours, proved to be significant. Participants who were enrolled full-time were more likely to persist into a second term than those students who were attending part-time. This finding is well supported in the literature and holds up for all students regardless of race or ethnicity.

Schartz and Washington (1999) investigated the retention of 213 first year African American females at a historically black college. The researchers selected 14 variables from the literature including high school rank and high school grade point average. In addition, students completed the Non-Cognitive Questionnaire along with the Student Adaptation to College Questionnaire. The NonCognitive Questionnaire yields eight scales and the student Adaptation to College Questionnaire yields four. 
Persistence from the initial fall session to a second session (spring) was the dependent variable. A stepwise multiple regression was used to identify predictor variables. Two variables were found to predict persistence: social adjustment and attachment to the college, with social adjustment being the most predictive.

McDaniel and Graham (2001) studied 1,949 first year students at a historically black, open admissions university. Each student completed an "Entering student Survey" which consisted of demographic information as well as academic information related to their prior high school experiences and their initial session at college. Persistence was measured one year after enrollment. The predictor variables that had the highest correlation coefficients with persistence were ACT test scores, ACT math sub score, students' perceptions about the adequacy of their prior education, high school grade point average, and high school rank.

The studies reviewed almost unanimously support the notion that social integration is the most important factor influencing the persistence of both African American males and females. Similarly, the studies highlight the importance that a strong high school record and full-time 
study have for the persistence of African American students. While useful in formulating possible interview questions, the research on the persistence of African American students does not directly answer the research question posed by the study, further supporting the need to complete it.

\section{Hispanic Student Persistence}

Hernandez and Lopez (2007) have noted that there is limited empirical research available on the behavior of Hispanic students in higher educational settings. As with studies focusing on African American students, the majority of the available literature has focused on describing characteristics that defined students who persisted in college.

Lester (2004) investigated the college persistence decisions of Hispanic students. Participants were 111 students enrolled in 2-year colleges located in southern California. The results indicated that the strongest predictor of college persistence was an active dispositional style followed by planning and positive reinterpretation and growth. College persistence decisions were found to be most negatively predicted by the coping styles of denial and the use of alcohol and/or drugs. 
Hurtado, Gener, Ramirez and Mayell (1994) studied 201 Hispanic students and reported that students who persisted until graduation used student services more than those students who did not persist. Rendon and Nora (1994) have summarized several factors that impact persistence of Hispanic students. These factors include financial resources, academic integration, commitment to their educational goals, poor academic preparation in high school, an absence of role models, and a lack of preparation in reading, writing and math. Unfortunately, the authors do not provide any empirical evidence to support their conclusions, and in fact, these conclusions could apply to any student regardless of ethnic or racial background.

In an earlier study, Rendon (1983) studied 227 Hispanic students enrolled in Texas community colleges. Rendon found a number of factors that predicted degree completion for these students including family socioeconomic status, student's age and gender, student's high school grades, the employment status of the student's father, perceptions of college services, number of other Hispanic peers, and perceived encouragement/support from faculty and staff. 
Hernandez (2000) completed a study exploring the retention of $10 \mathrm{Hispanic}$ students. The participants ranged in age from 21 to 25 years and included five men and five women. The analysis and interpretation of the interviews generated 11 major themes that students felt impacted their retention. The belief in and the realization that they possessed the potential to succeed in college was a primary reason for persistence expressed by all participants. Possessing a positive mental outlook was associated with having the desire to succeed. Friends, family, and peers all were reported by participants to have had a positive impact on their staying in school. All participants mentioned the importance of having a positive relationship with faculty and staff. Next, although their level of involvement varied and the type of organizations they choose to interact with were quite diverse, all students felt that being involved in their school community was an important reason as to why they stayed in school. Not surprisingly, financial aid was reported by students to be a critical factor for them to stay in school.

Butner, Carter, and Brown (2004) interviewed 11 successful Hispanic undergraduate students. The researchers identified the importance of a student's realization that 
they did possess the potential to succeed and that they belonged in college (self-esteem), and that the students realized that they were responsible for their success. Butner and his associates noted that all of the successful students had a strong desire to be a role model for others in their family in terms of education and make their families proud.

Zurita (2004) reported on the experiences of 10 Hispanic undergraduate students at a large Midwestern university in an attempt to discover factors that differentiated Hispanic students who persisted from those who did not. Persistence was defined in this study as having graduated from their program of study. Five of the students questioned eventually graduated while five did not. Participants in the study were recipients of a special need-based scholarship program aimed at increasing the number of traditionally underrepresented groups at the university. Semi-structured interviews focused on five areas that the investigator had identified from the literature: differences between student's home and school cultures, financial issues, academic issue, institutional issues, and personal issues. The investigator noted that both groups of students reported similarities in their 
perception of their home cultures (working families with both parents at home), perceptions of their university culture (White), financial issues (none, as these students had multiple sources of financial aid, including the special scholarship program that was used to identify them), parental support (limited), and feelings of being academically unprepared to handle college level work. Several differences were identified between groups. First, students who did not persist reported experiencing academic difficulties as all were dismissed from the university due to academic reasons. Students who did not persist reported a difficult home to school transition largely due to the differences in economic standards both at home and at the high schools that they had attended. Finally, students who did not graduate reported lower goals for their education as compared to the students who completed their programs of study .

Pidcock, Fischer, and Munsch (2001) reviewed the family, personality, and social risk factors that impacted the retention rates of first year Hispanic students. The researchers interviewed 34 incoming freshmen students and also asked them to complete several research instruments focusing on family functioning. The investigators found 
that Hispanic students enrolled for a second year of college at a somewhat lower percentage than non-Hispanic white students (67\% vs. 79.5\%). Hispanic females left school at far greater rates (39\%) than did their nonHispanic white counterparts (9\%). This relationship was reversed when males were examined. Twelve percent (12\%) of Hispanic males left school after their first year as opposed to $31 \%$ of the white counterparts. During follow up interviews, the investigators concluded that the Hispanic females who did not return for a second year shared significant family problems which forced them to stay home and assist in the management of their parents' households including the care of younger siblings.

\section{Summary}

The main research question in this study was: What factors differentiate students who persist into their second session of study from those who drop out? This chapter presented and reviewed the relevant literature related to this topic.

Although limited in applicability to the population and setting that this study investigated, it is important to review the general literature that has empirically attempted to identify factors that differentiate students 
who persist from those who do not along with the limited number of studies that have investigated this topic within for-profit institutions. This review allows the researcher to interpret findings from the study in light of the entire body of literature that is available on the subject. Indeed, several of the themes identified in the limited literature that have focused on for-profit institutions can be seen in studies which have focused on public and private institutions. For example, both groups suggest that prior academic preparation, the quality of faculty interactions with students, a student's commitment to completing his or her education, and their self-perceived efficacy about their academic skills are important factors that can help determine persistence regardless of institutional setting. The existing literature and, in particular those studies that have focused on for-profit institutions, is hampered by methodological weaknesses. First, the majority of quantitative studies reviewed either report low magnitudes of prediction in their results or do not report any estimates of magnitude. Second, most qualitative studies reviewed lack a comparison group. Third, many studies were limited by small sample sizes. Finally, research studies in the area tend to over rely on reporting 
what participants believed or thought was important for their success. These expressions, while valid, might be tainted by issues like social desirability and intrusive researcher effects.

These methodological weaknesses and the relative dearth of empirical research focusing on retention in the for-profit higher education sector underscore the need for this study. Chapter 3 describes the method that was used to carry out the study. 
CHAPTER III

\section{Method}

This chapter begins with the purpose of the study and the research question presented in Chapter 1. The research design and study participants are discussed next. Sections detailing the instruments, procedures and data analysis that were utilized follow. The chapter concludes with a summary .

\section{Purpose of the study}

The purpose of this study was to explore what specific factors are related to student persistence in for-profit colleges and universities. Specifically, this mixed method study investigated the factors that differentiated students who persisted beyond the first session at a regionally accredited for-profit university from those who do not.

\section{Research Question}

The research question for this study was: What factors differentiated for-profit college students who persisted into their second session of study from those who dropped out?

\section{Research Design}

This study utilized a mixed methods research design. Tashakkori and Creswell (2007, p. 3) "have broadly defined 
mixed methods as research in which the investigator collects and analyzes data, integrates the findings, and draws inference using both qualitative and quantitative approaches or methods in a single study or a program of inquiry." Johnson, Onwuegbuzie, and Turner (2007) define mixed methods research as a type of research design where the investigator mixes or combines qualitative and quantitative techniques, analysis, and concepts into a single study or a series of related research investigations. A multi-strand, mixed methods design (Teddlie \& Tashakkori, 2006), consisting of three strands was conducted. Strands 1 and 2 collected and analyzed students' self-reported data. The third and final strand of the study utilized a predominantly qualitative approach, with a purposeful sample that emerged from the results of the previous strands, and was employed in semi-structured, funnel-sequenced interviews. Each strand will be described in more detail in separate sections later in this chapter.

\section{Setting}

The population for this study was new undergraduate students who enrolled at DeVry University-South Florida during 2008. Students did not receive compensation or classroom credit for participation. New students at DeVry 
begin their program of studies at any one of six entry points that begin in January and is repeated every 8 weeks. All new students were eligible to be included in the study sample.

DeVry University is a for-profit, regionally accredited university, with campuses operating across the United States and Canada. The institution's historical roots originate in 1931 when Dr. Herman DeVry founded the DeForest Training School in Chicago, Illinois, to educate students for technical careers in the fields of electronics, motion pictures, radio, and later, television. As the institution matured and grew, the name was changed to DeVry Technical Institute in 1953, and then again in 1968 when it became the DeVry Institute of Technology. Over the years, DeVry has expanded its curricula and degree offerings. In 1957, it achieved associate-degreegranting status in electronic engineering technology and 12 years later was authorized to grant bachelor's degrees in the same discipline as well as computer engineering technology. In 1966, DeVry was purchased by the Bell and Howell Education Group, and began a significant geographic expansion, growing from 2 locations in Illinois to 11 locations in eight states and in two Canadian provinces. 
DeVry's curricula expanded further, as additional

bachelor's degree programs in computer information systems, accounting, business administration, and network and communications management were introduced.

Currently, DeVry operates over 100 locations enrolling students in both graduate and undergraduate programs. Focusing on career-oriented, practitioner-based education in three broad areas, DeVry offers programs in Business and Management, Engineering and Telecommunications, and Allied Health. The university offers Associate, Bachelor's and Master's level degrees in these areas. The university is accredited by the Higher Learning Commission of the North Central Association (NCA) and is licensed to operate in 26 states. In addition to regional accreditation, DeVry's programs are also accredited by discipline specific accrediting bodies where appropriate. DeVry can be categorized as an urban/suburban commuter/career university with less competitive entrance requirements.

DeVry University is owned by DeVry, Inc., whose stock trades on the New York Stock Exchange. DeVry, Inc. is a diversified educational services company. In addition to DeVry University, DeVry, Inc. owns Becker Professional Review, which provides continuing professional education to 
the accounting and financial services industries, Ross University, which awards both doctor of medicine (MD) and doctor of veterinary medicine (DVM) degrees, Chamberlain College of Nursing, which awards associate and bachelor's degrees in nursing, Carrington College, and DeVry-Brasil.

\section{Method}

\section{Strand One}

During this strand, self-reported data describing students' pre-enrollment characteristics and feelings about attending college were collected and analyzed. The following sections describe the participants, variables and their measurement, data collection procedures, and the data analysis plan that were utilized in this strand.

Participants. All incoming students entering DeVry University-South Florida during 2008 were included in the population for Strand One. A total of 445 students were identified to have begun their studies during 2008. Table 1 summarizes key demographic data that characterized the student population at DeVry South Florida as of November, 2007. 
Table 1

Demographic Information: DeVry University South Florida

Characteristic

Percentage

Racial or Ethnic Origin

African descent

32.4

Asian

1.6

White or Caucasian

8.5

Hispanic

51.4

Other

6.1

Gender

Males

$58 \cdot 3$

Females

41.7

Age

18 to 21

26

22 to 25

17

25 to 30

38

30 to 40

13

40 and over

6

Variables and their measurement. Pre-enrollment characteristics and variables were measured by the college Student Inventory, Form B (CSI-B), which was designed specifically for incoming first year students. Developed 
from the Stratil Counseling Inventory (Stratil, 1984), the instrument identifies the specific motivational variables that are most closely related to persistence and academic success in college (Hogan, 2004). The original version of the CSI-B was published in 1984 and subsequently revised in 1988 and 2000. The variables that were measured during Strand One are listed in Table 2 .

Table 2

Strand One Variables and Their Sources

Variable

Source

Gender

University Records

Ethnicity

University Records

Age

University Records

H.S. GPA

CSI-B

H.S. Rank

CSI-B

Hours planning to work

CSI-B

Perceived academic efficacy

CSI-B

Mother's educational history

CSI-B

Father's educational history

CSI-B

Degree aspiration

CSI-B

Timing of application

CSI-B

(table continues) 
Table 2 (continued)

\begin{tabular}{|c|c|}
\hline Variable & Source \\
\hline Study Habits & $\mathrm{CSI}-\mathrm{B}$ \\
\hline Intellectual Interests & CSI-B \\
\hline Verbal Confidence & CSI-B \\
\hline Math Confidence & CSI-B \\
\hline Desire to Finish College & CSI-B \\
\hline Attitude toward Educators & CSI-B \\
\hline Family Emotional Support & CSI-B \\
\hline Sense of Financial security & CSI-B \\
\hline Opinion Tolerance & CSI-B \\
\hline Career Closure & CSI-B \\
\hline Sociability & CSI-B \\
\hline Academic Assistance & CSI-B \\
\hline Personal Counseling & CSI-B \\
\hline Social Enhancement & CSI-B \\
\hline Career Counseling & CSI-B \\
\hline Financial Guidance & CSI-B \\
\hline Sociability & CSI-B \\
\hline 1st session Student's GPA & University records \\
\hline $\begin{array}{l}\text { Enrollment status } \\
\text { first term }\end{array}$ & University records \\
\hline
\end{tabular}


The CSI Form B (CSI-B) was launched in 2000 and developed as a shorter version of the original CSI introduced in 1988. Form B contains 100 items as opposed to the original CSI (now known as Form A) which has 194 items. Form B can be taken as a paper/pencil instrument or can be completed directly online by the student. This study utilized the computerized version of the test. The instrument begins with a short introductory paragraph and continues with three sections. The first section asks students for his or her name, age, gender, and identification code. The second section contains 10 multiple choice questions that focus on additional demographic information, a question about their perceived academic efficacy, and a question about the timing of their decision to apply for admission. The final section of the instrument consists of 90 items that measure a variety of attitudes toward college. Students use a 7-point Likert scale to answer each question in this section (Stratil, 2001).

Student responses to the 100 questions are collapsed by the test publisher into 17 different scales which can be organized into four domains (Stratil, 2001). The domains and scales are summarized in Table 3 . 


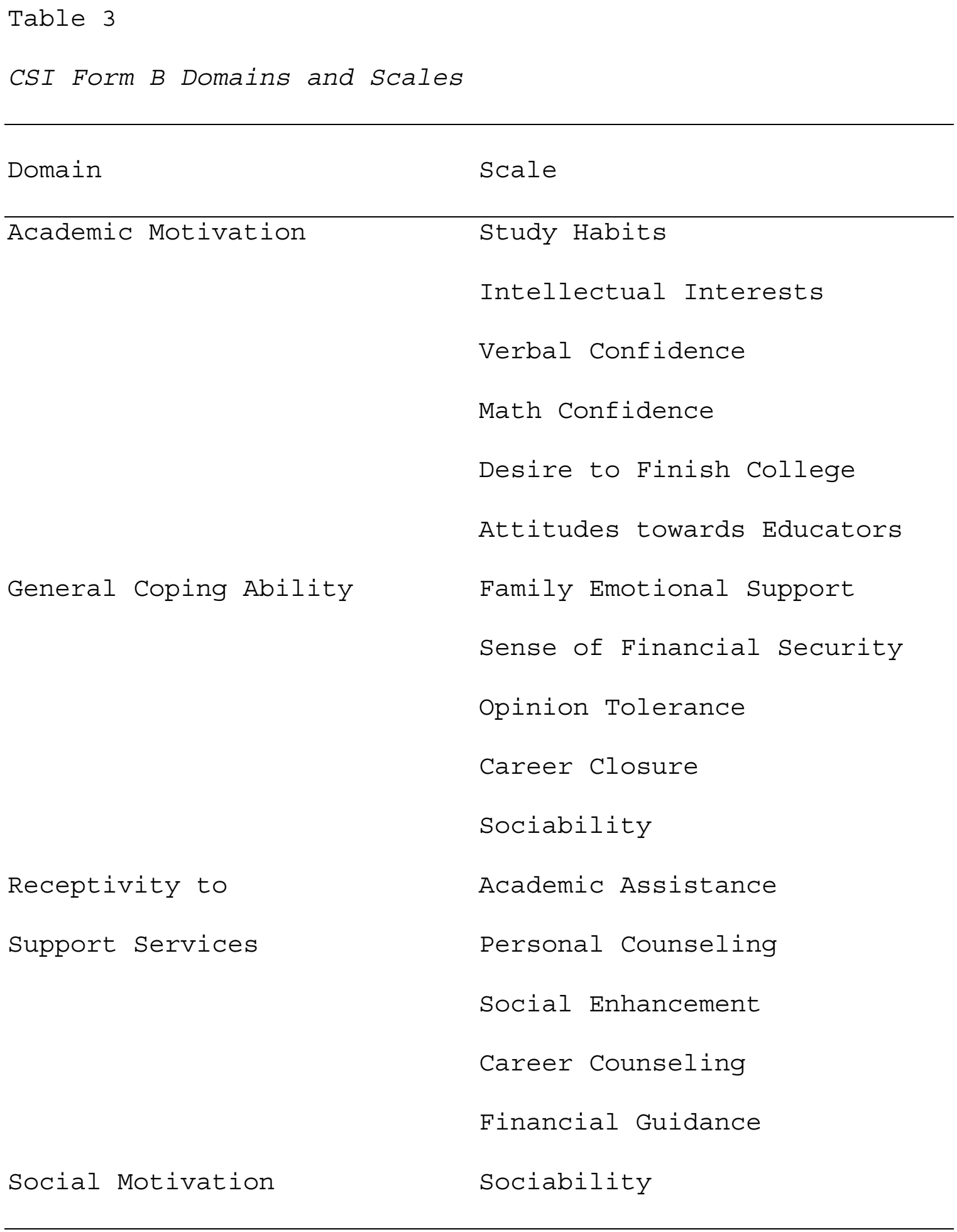

The scoring rubric for the CSI-B generates three summary reports. The advisor report provides information 
about the student's attitudes and motivation in percentile ranks. Higher stanine scores imply greater risk. The CSI also contains an internal validity measure designed to identify respondents who randomly completed the instrument. Background information provided by students regarding his or her high school academic experience, family background, and admission test scores are also included in this report. An abridged version of the advisor report is produced for the student as well as institutional summary and planning report (Stratil, Schreiner, \& Noel, 1993).

A reliability analysis was conducted in 2000 using 12,590 responses to the items. Cronbach's alpha coefficient was calculated for each scale (Noel-Levitz, 2002). Separate coefficients were calculated for 2-year and 4-year colleges. The alpha coefficient for 4 -year schools was .806, while the coefficient for a 2-year school was .78. The combined alpha coefficient was .793. These coefficients compare favorably with other respected research instruments (Basha \& Lunenburg, 2001). For example, the Myers-Briggs Type Indicator (MBTI) has an average alpha coefficient of .81 and the California Psychological Inventory (CPI) reports an alpha coefficient of .72 . 
Validity was measured by stratil (1988) using various statistical analyses. These analyses showed that the CSI scales correlate significantly with their target criterion variables. Schreiner (1991) reported a psychometric study on the CSI and noted that factor analysis confirmed that the inventory items loaded on factors that corresponded to their designated scales. In this study, internal consistency reliability (as measured by Cronbach's Alpha) was calculated and used as an indicator of data reliability. A sample CSI-B is included in Appendix A.

Data collection procedures. All incoming new students were asked to complete the online version of the CSI-B during their first week of enrollment. The time that students took to complete the inventory ranged from 30 to 45 minutes. Demographic data available from university records and the scaled scores from the CSI-B were collected and recorded by the investigator. Each student's college GPA as well as his or her enrollment status for their second session of study was also recorded. Data was recorded for all students who enrolled during 2008 .

Data analysis. Discriminant analysis was utilized to examine the data collected during strand One. Discriminant analysis (DA) is used to determine which continuous 
variables discriminate between 2 or more groups. Specifically, DA analyzes the observed mean differences of discriminating variables in an effort to differentiate between 2 or more groups (Tabachnick \& Fidell, 2007). If the DA identifies variables that differentiate between groups, the performance of the resulting discriminant function can be tested by classifying new a priori cases or records. In this study, DA allowed the researcher to determine which combination of pre-entry variables, if any, differentiated those students who persisted into a second session from those who dropped out.

The initial DA included all members of the sample. DA can tolerate unequal sample sizes. Upon completion of the initial analysis, tests of significance (e.g., Wilks' lambda) were conducted. SPSS Graduate Pack 15.0 for Windows was the statistical package used for all calculations.

\section{Strand Two}

Strand Two built upon the results of Strand One and collected and analyzed self-reported questionnaires based on the Theory of Planned Behavior (TPB; Ajzen, 2006).

Participants. All new students entering DeVry University-South Florida are required to take a common course on Critical Thinking. A total of 125 students 
enrolled in this class during their first session were asked to complete the TPB questionnaire. Of that number, 117 students agreed to participate in the study and completed the questionnaire.

Variables and their measurement. The Theory of Planned Behavior states that human action is determined by three forces: (a) behavioral beliefs, (b) normative beliefs, and (c) control beliefs held by an individual (Azjen, 1991). These constructs are latent variables and can only be inferred from responses provided by an individual. In combination they lead to the formation of intent to perform the behavior in question. A 29-item questionnaire was designed using the specifications defined by Ajzen (2006) and Francis and her associates (Francis et al., 2004) in their guides on the development of TPB questionnaires. The steps to create the questionnaire were (a) defining the population of interest and deciding how to best select a representative sample from this population; (b) define the behavior of interest in terms of its target, action, context and time elements; (c) decide how to best measure the behavioral intentions; (d) determine the most frequently perceived advantages and disadvantages of completing the behavior; (e) determine the most important 
people or groups who would approve or disapprove of the behavior; (f) determine the perceived barriers to completing the behavior; ( $g$ ) determine the perceived facilitating factors that could make it easier to adopt the behavior in question; and (h) pilot test the questionnaire and reword items if needed. The TPB questionnaire that was used in the study is included in Appendix B.

Data collection procedures. Students were asked to participate in the study as per the established informed consent guidelines at Florida International University and DeVry University. Participation in the study was voluntary and no incentives or inducements were offered to participants. If students agreed to participate, they were given a TPB paper and pencil questionnaire described in the previous section and asked to complete it. The questionnaire took participants an average of between 10 to 15 minutes to complete. Information about continuation or discontinuation of studies in the college was retrieved from the university information system by the investigator.

Data coding and analysis. Completed questionnaires were coded and scored. A discriminant analysis was used to determine the extent to which the components of the Theory 
of Planned Behavior can differentiate those who continued into a second session of study versus those who did not.

\section{Strand Three}

The final strand consisted of semi-structured, funnelsequenced interviews. Interviews provide the researcher with a forum to obtain richer and fuller responses from participants (Merriam, 1998). In this study, the interviews provided a more in-depth understanding of the findings of the other strands. Funnel sequenced interviews begin with general questions and keep increasing in specificity until the concluding questions are very specific. Two types of questions were used during the interview. Main or general questions were utilized to initiate the discussion. Main questions are broad in scope and encourage the participant to reflect on their experiences. Probing questions were used to clarify or focus the interviewees' responses to the main questions (Merriam, 1998).

Participants. A purposeful sample aimed at maximizing sample variation was utilized in this strand. A sample is considered to be purposeful when a researcher deliberately identifies and selects individuals who have experience with the major topic or experience being studied (Creswell \& Plano Clark, 2007). These interviews were conducted with 
the goal of clarifying and amplifying the results from Strands 1 and 2 . In addition, the interviews were structured so that additional factors that might influence persistence but were not discovered in Strands 1 and 2 may be identified. A group of 24 students who had continued into a second session were contacted to participate in the interviews and 8 agreed to participate. Contact for this group of students was either by telephone or e-mail. A group of 24 students who had dropped out were contacted to participate. Contact with these students proved to be problematic. Telephone numbers and e-mail addresses were retrieved from school records but most of these were either incomplete or incorrect. An additional attempt to contact these students was made by sending them a letter via the postal system. Three students who had dropped out responded to the outreach efforts and agreed to participate but did not show up for their scheduled interview. Follow-up contact (via telephone, e-mail and postal mail) was attempted with these individuals, but all efforts to reschedule the interview were unsuccessful.

Variables and their measurement. The data generated from Strands 1 and 2 were analyzed and an interview guide 
was developed from this analysis. The interview guide that was utilized is included in Appendix C.

Data collection procedures. Interview sessions were digitally recorded and archived according to Florida International University's Regulations for Thesis and Dissertation Preparations. A verbatim transcribed summary was prepared by the researcher for data analysis. Interviews ranged in length from 45 minutes to 1 hour. Participants' confidentiality was maintained throughout the process as provided for by the informed consent policies and procedures of Florida International University and DeVry University .

Data analysis. The data generated during this phase of the study were analyzed by using a process detailed by Creswell (2003). First the data were organized and transcribed. After this was completed, the data analysis began. A preliminary exploratory analysis was completed. This step consisted of exploring and reading the data by the researcher so that a general feel for the data could be developed. A qualitative codebook was developed next. After the codebook was developed, the researcher recorded a list of statements from the transcripts. The next step in the data analysis was to begin the coding process. Each 
statement was coded and given a corresponding label. Next, an inductive process was initiated where the preliminary codes was grouped and collapsed into broad themes. These broad themes were categorized and, where appropriate, layered and interrelated into a smaller set of themes.

\section{Summary}

This chapter described the method that was used to conduct this study. First, the purpose of the study and the research questions were presented again to frame the subsequent sections. These sections contained descriptions of the population, research sample, data collection, data analysis, and procedures that were planned. The next chapter will present the results of the investigation. 
CHAPTER IV

\section{Results}

The main research question posed in this study was: What factors differentiate students attending a for-profit university who persist into their second session of study from those who drop out? A multi strand mixed-methods research design was utilized. The results of the data from each strand are reported in this chapter. First, demographic information about the participants is reviewed, and then the results from strands 1,2 and 3 are presented.

\section{Participant Characteristics}

All students that were admitted to DeVry UniversitySouth Florida during 2008 were identified for inclusion in Strand One. A total of 445 students were identified using this guideline. Each new student completed the College Student Inventory, Form B (CSI-B). The CSI-B identified specific motivational variables that are closely related to persistence and academic success in college (Hogan, 2004). In addition, the student was asked to respond to a number of demographic questions. Of the 100 questions that each participant answered for the CSI-B, 9 questions requested background information. These questions asked students to self-report their (a) age, (b) gender, (c) ethnicity, (d) 
the highest academic degree that they aspired to, (e) their GPA during their senior year of high school, (f) the educational backgrounds of their mother and father, $(g)$ the amount of time they planned to work during their college studies, and (h) when they had begun their college decision making process.

Each student's responses to the College student Inventory, Form B (CSI-B) were retrieved from their student record and downloaded to an Excel spreadsheet. In turn, these data were entered into SPSS version 15.0 for analysis. No data imputations or transformations were needed in this study. The results of the analysis of the demographic variables are summarized in the following section.

\section{Age, Gender and Ethnicity}

The mean age of the research sample was 24.5 years with a minimum age of 18 and a maximum age of 56. There were no significant differences between the average age of the students who persisted (24.6) and those students who dropped out (24.4). Students of Hispanic background accounted for $48 \%$ of the participants. These students came from Spanish language-speaking countries in the Caribbean, Central America, and South America. The next largest group 
(31\%) self-identified themselves as being black and comprised students who came from the Caribbean, Africa, and the United States. The age, gender and ethnicity composition of the sample closely matches the age, gender and ethnicity of the DeVry University-South Florida campus. The sample is also similar to DeVry students who attend the institution across the United States with the exception of ethnicity. Hispanics are over-represented and non-Hispanic whites under-represented in the research sample. Approximately $60 \%$ of the 445 participants were male and $40 \%$ female. Males were just as likely to persist (133) as they were to drop out (132). Females on the other hand were much more likely to persist (111) as opposed to dropping out (69). Similarly, more than double the number of male students (133) dropped out when compared to female students (69) .

These findings support other studies that have reported significantly higher dropout rates for male minority students (Hernandez, 2000; Hernandez \& Lopez, 2007; Littleton, 2001; Swail, 2000; Swail et al., 2003); however, the findings run counter to the overall gender ratios evident in for-profit universities as a whole. Chung (2009) has reported that females make up $61 \%$ of the 
students enrolled in for-profit institutions. A possible explanation for the difference between the study sample and the data reported by Chung (2009) is that the majority of for-profit female students enroll in certificate or associate degree programs. DeVry University offers only three associate degree programs and no undergraduate certificate programs. The research sample is overrepresented by students enrolled in bachelor degree programs.

The age, race/ethnicity and gender of the participants are summarized in Table 4.

Table 4

Age, Race/Ethnicity and Gender of Participants

\begin{tabular}{cccc}
\hline & $\begin{array}{c}\text { Total } \\
\text { Population }\end{array}$ & Persisted & $\begin{array}{c}\text { Did not } \\
\text { Persist }\end{array}$ \\
Average Age & 24.5 & 24.6 & 24.4 \\
Ethnicity & 12 & 9 & 3 \\
Asian & 140 & 80 & 60 \\
Black & 217 & 114 & 103 \\
Hispanic & & & (table continues)
\end{tabular}


Table 4 (continued)

\begin{tabular}{|c|c|c|c|}
\hline & $\begin{array}{c}\text { Total } \\
\text { Population }\end{array}$ & Persisted & $\begin{array}{l}\text { Did not } \\
\text { Persist }\end{array}$ \\
\hline White & 32 & 17 & 15 \\
\hline Other & 44 & 23 & 21 \\
\hline Total & 445 & 243 & 202 \\
\hline \multicolumn{4}{|l|}{ Gender } \\
\hline Male & 265 & 133 & 132 \\
\hline Female & 180 & 111 & 69 \\
\hline Total & 445 & 243 & 202 \\
\hline
\end{tabular}

\section{Degree Aspirations and High School GPA}

Participants were asked about their degree aspirations and to self-report their high school senior year grade point average (GPA). Higher high school grades have been identified in the literature as a factor that is a strong positive predictor of retention (Kuh, Kinzie, Buckley, Bridge, \& Hayek, 2007; Lotkowski, Robbins, \& Noeth, 2004 ; Seidman, 2007). More than half the participants reported that their ultimate educational goal was to complete a master's degree. This goal might be considered lofty when compared to the participants' self-reported performance during their senior year of high school. No significant 
differences are apparent when comparing those students who persisted from those who did not, although the students that persisted reported slightly higher interest in obtaining either a master's or doctoral degree. Roughly half of the respondents reported that they had been average students in high school with either a C or C+ senior year GPA. Students who persisted reported better senior year GPAs with 55\% reporting that they had attained either an $A$ or B GPA during their senior year. The data on degree aspirations and senior year high school GPA are summarized in Table 5.

Table 5

Participants' Degree Aspirations and Senior Year High School GPA

\begin{tabular}{|c|c|c|c|}
\hline \multicolumn{2}{|c|}{$\begin{array}{c}\text { Total } \\
\text { Population }\end{array}$} & \multirow[t]{2}{*}{ Persisted } & \multirow[t]{2}{*}{$\begin{array}{l}\text { Did not } \\
\text { Persist }\end{array}$} \\
\hline $\begin{array}{l}\text { Degree } \\
\text { Aspirations }\end{array}$ & & & \\
\hline Associate's & 9 & 5 & 4 \\
\hline Bachelor's & 134 & 69 & 65 \\
\hline Master's & 244 & 133 & 111 \\
\hline
\end{tabular}


Table 5 (continued)

\begin{tabular}{cccc}
\hline & $\begin{array}{c}\text { Total } \\
\text { Population }\end{array}$ & Persisted & $\begin{array}{c}\text { Did not } \\
\text { Persist }\end{array}$ \\
\hline Doctorate & 58 & 36 & 22 \\
Total & 445 & 243 & 202 \\
Senior Year GPA & & & \\
A Average & 18 & 10 & 8 \\
B Average & 104 & 53 & 51 \\
B+ Average & 106 & 71 & 22 \\
C Average & 41 & 19 & 86 \\
C+ Average & 176 & 90 & 202 \\
Total & 445 & 243 & \\
\hline
\end{tabular}

\section{Parents' Educational Background}

Participants were asked to report their parent's educational background. Less than $20 \%$ of the participants' fathers had attained a bachelor's degree or higher. Only 15.7\% of participants' mothers had attained a bachelor's degree or higher. Conversely, $23.2 \%$ and $24.3 \%$ of the participants' mothers and fathers had not completed high school. This data is lower than what has been reported in the literature. In an analysis of the National Education 
Longitudinal Study of 1988 (NELS:88) and the NELS:88/2000

Post-secondary Education Transcript Study (PETS:2000), Chung (2009) reported that 55\% of proprietary students' parents had pursued or completed education beyond high school. The responses to these questions are summarized in Table 6 .

Table 6

Parents' Educational Backgrounds

Total

Population \% Persisted \%
Did not

Persist \%

Father's Educational Background

$\begin{array}{lccc}\text { Elementary } & 8.1 & 9.1 & 6.9 \\ \text { Some HS } & 16.2 & 13.6 & 19.3 \\ \text { HS Diploma } & 32.6 & 36.6 & 36.1 \\ \text { Some College } & 19.6 & 20.2 & 18.8 \\ \text { Bachelor's } & 10.6 & 8.2 & 13.4 \\ \text { Master's } & 4.3 & 6.6 & 1.5 \\ \text { Doctorate } & 4.9 & 5.8 & 4.0 \\ \text { al } & 100.0 & 100.0 & 100.0\end{array}$

Mother's Educational Background
Elementary
7. 9
8.6
6.9 
Table 6 (continued)

\begin{tabular}{cccc} 
& $\begin{array}{c}\text { Total } \\
\text { Population } \%\end{array}$ & Persisted $\%$ & $\begin{array}{c}\text { Did not } \\
\text { Persist \% }\end{array}$ \\
Some HS & 15.3 & 11.9 & 19.3 \\
HS Diploma & 30.8 & 32.1 & 34.2 \\
Some College & 28.1 & 29.6 & 26.2 \\
Bachelor's & 8.8 & 8.6 & 8.9 \\
Master's & 4.9 & 6.2 & 3.5 \\
Doctorate & 2.0 & 2.9 & 1.0 \\
Total & 100.0 & 100.0 & 100.0 \\
\hline
\end{tabular}

\section{Expected Work Hours and Decision to Apply}

Finally, participants responded to two questions that asked them how many hours they planned to work while enrolled in school and about the timing of their decision to apply for admission to DeVry. Prior research studies have reported that students who work more than 15 hours per week while enrolled in college were at risk of not completing their studies (King, 2002; Torres, Gross, \& Dadashova, 2010). Over 70\% of the respondents reported that they planned to work at least 20 hours per week while enrolled in college with over $50 \%$ reporting that they 
planned to work more than 30 hours per week. Only 7\% reported that they did not plan to work while in school. While there were no major differences with respect to how many hours each group planned to work (70\% of those students who persisted reported that they planned to work at least 20 hours per week as opposed to $76.7 \%$ of those students who did not persist). Only $15.6 \%$ of the students who persisted reported that they planned to work an equivalent of a full-time work schedule, whereas $26.2 \%$ of students who did not persist reported that they planned on working full-time.

With respect to when they had decided to attend college and, specifically DeVry University, $45.6 \%$ of the participants reported that they had decided to attend DeVry either a few days before enrolling or a few weeks before. No major differences between those students who persisted versus those who dropped out were evident. The data for both of these questions are summarized in Table 7 . 
Table 7

Participants' Planned Employment

\begin{tabular}{|c|c|c|c|}
\hline \multicolumn{2}{|c|}{$\begin{array}{c}\text { Total } \\
\text { Population }\end{array}$} & Persisted \% & \multirow[t]{2}{*}{$\begin{array}{l}\text { Did not } \\
\text { Persist \% }\end{array}$} \\
\hline Planned Hours of & Outside & Employment & \\
\hline 0 hours & 7.0 & 7.4 & 6.4 \\
\hline 1-10 hours & 7.2 & 9.5 & 4.5 \\
\hline 11-20 hours & 12.6 & 12.8 & 12.4 \\
\hline 21-30 hours & 16.6 & 21.4 & 10.9 \\
\hline 31-40 hours & 36.2 & 33.3 & 39.6 \\
\hline $40+$ hours & 20.4 & 15.6 & 26.2 \\
\hline Total & 100.0 & 100.0 & 100.0 \\
\hline \multicolumn{4}{|l|}{ Decision to Enroll } \\
\hline Days before & 9.4 & 8.6 & 10.4 \\
\hline Weeks before & 36.2 & 36.2 & 36.1 \\
\hline Months before & 54.4 & 55.1 & 53.5 \\
\hline Total & 100.0 & 100.0 & 100.0 \\
\hline
\end{tabular}

\section{Summary}

Analysis of the participant characteristic data revealed that our research population was older than the typical college student with an average age of 24.5 . The study sample was over represented with students of Hispanic 
descent (48.8\%) and under represented by non-Hispanic white students (7.2\%) limiting the generalizability of the data. The study sample was also over represented by males (60\%). The students who comprised the research sample reported that for the most part (96\%), they had received grades of $\mathrm{B}^{\prime} \mathrm{S}$ and $\mathrm{C}^{\prime} \mathrm{s}$ during their senior year of high school. Despite this middle of the road academic record, students in the research sample strived to achieve multiple degrees in college. Almost $68 \%$ of the students reported that their academic goal was to achieve either a master's or doctorate degree. Less than half (44\%) of the students who participated in the study had parents who had had some experience with college. Students reported that they would pursue aggressive work schedules while attempting to begin or continue their educations. Finally, students reported that they had spent at least some time in deciding about pursuing a college education and that enrolling in classes could not be considered to be a "last minute" decision.

The analysis of the participant characteristics also begins to provide an answer to the research question guiding this study: What factors differentiate students attending a for-profit university who persist into their second session of study from those who drop out? It does 
not appear that a student's age, degree aspirations or when they decide to pursue college enrollment differentiate between those students who persist from those who drop out. Similarly, the educational background of a student's parents does not appear to differentiate between the two groups.

However, it appears that gender may be a factor that differentiates between students who persist from those that drop out. A higher senior year GPA and the amount of hours worked while attending college may also differentiate between the two groups. The data analysis used in this section was descriptive in nature and did not test for any relationships. The next section of this chapter describes the results of more sophisticated data analysis techniques that were utilized to answer the research question for this study .

\section{Strand One Results}

The remaining 91 questions in the college student Inventory, Form B, asked the participants about a variety of attitudes and issues related to college (Noel Levitz RMS Coordinator's Guide, 2004). The answers to these questions were utilized to answer the main research question posed in this study: What factors differentiate students who persist 
into their second session of study from those who drop out? A number of scales (23) are constructed from the 91 questions and provide a snapshot of each respondent's selfreported academic motivation, general coping ability, and receptivity to support services that can be provided by the institution. A percentile rank of $50 \%$ is considered average when compared to the scores of all students who take the CSI-B throughout the United States.

The students who participated in the study indicated that were very receptive to institutional support services. Students reported that they were more open to academic assistance, career planning, financial guidance, social enrichment, and institutional assistance that would allow them to complete their educational goals than other college students who take the CSI-B across the United States. Table 8 summarizes the participants' average percentile ranks for the scales generated by the CSI-B in two groups. The scales where students scored above the national norm are clustered in one group while those scores where students scored below the national norm are clustered in the second group. 
Table 8

Summary of CSI-B Generated Scales

Scale

Avg. Percentile

Above the National Norm

Receptivity to Academic Assistance

64.2

Receptivity to Institutional Help 61.9

$\begin{array}{ll}\text { Receptivity to Career Planning } & 60.9\end{array}$

$\begin{array}{ll}\text { Likely to Transfer } & 60.3\end{array}$

$\begin{array}{ll}\text { Tolerant of Other Opinions } & 57.3\end{array}$

$\begin{array}{ll}\text { Planned their Career } & 57.2\end{array}$

$\begin{array}{ll}\text { Receptivity to Financial Guidance } & 56.2\end{array}$

$\begin{array}{ll}\text { Attitude towards Educators } & 55.5\end{array}$

$\begin{array}{ll}\text { Desire to Finish College } & 55.3\end{array}$

Perceived Academic Difficulty in College 55.2

$\begin{array}{ll}\text { Feel Prepared for College } & 53.7\end{array}$

Receptivity to Social Enrichment 53.4

$\begin{array}{ll}\text { Study Habits } & 52.2\end{array}$

$\begin{array}{ll}\text { Dropout Proneness } & 51.8\end{array}$

$\begin{array}{ll}\text { Sociability } & 51.7\end{array}$

$\begin{array}{ll}\text { Verbal Confidence } & 51.1\end{array}$

$\begin{array}{ll}\text { Emotional Support from Family } & 50.4\end{array}$ 
Table 8 (continued)

Scale

Avg. Percentile

Below the National Norm

Intellectual Interests

49.8

Confidence with Math

49.4

Perceived Educational Stress

48.4

High School Preparation

48.3

Perceived Academic Stress

46.4

Sense of Financial security

44.4

Parent's Education

42.3

In an effort to validate that the CSI-B was an

effective tool for the population being investigated, an

exploratory factor analysis was performed on the 23 summary scales generated by the CSI-B listed in Table 8 using principal component analysis with the varimax method of orthogonal rotation.

Factor analysis is a statistical technique that can be used to determine subsets of variables that are independent of each other within a larger single set of variables (Tabachnick \& Fidell, 2007). Factors are representative of underlying processes that generate the correlations amongst 
the variables being measured. By examining the variables, the goals of factor analysis are to summarize the patterns of correlations and reduce the data to a few factors that can be utilized for further research (Tabachnick \& Fidell, 2007).

The factor analysis generated 16 factors from the original 23 CSI summary scales. The varimax method of orthogonal rotation was utilized to enhance interpretation (Tabachnick \& Fidell, 2007). Four factors were identified that accounted for 54.5\% of the variance after rotation. Eigenvalues are equivalent to correlations and eigenvalues less than 1 are not as relevant as those with values greater than 1 (Tabachnick \& Fidell, 2007). The eigenvalues generated by the analysis were reviewed and any factor with a value greater than 1 was included in the solution. The Scree plot was also reviewed and examined to confirm the number of factors. Factor 1 accounted for $21.8 \%$ of the variance, Factor 2 accounted for 16.9\%, Factor 3 accounted for $9.0 \%$, and Factor 4 accounted for $6.7 \%$. Table 9 summarizes the variance explained by each factor. 


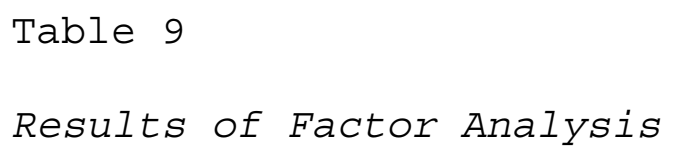

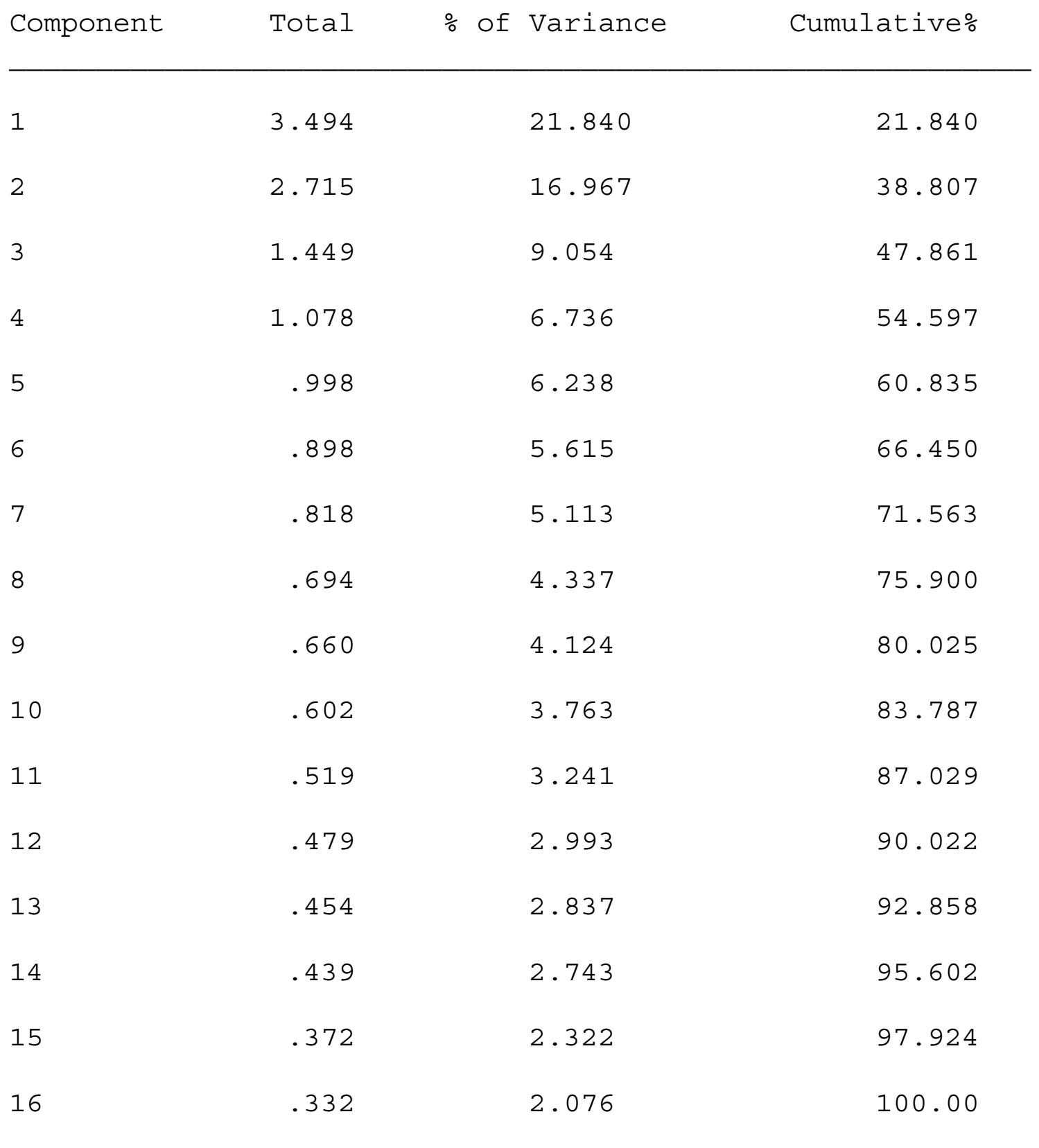

An analysis of the findings reveals that data singularity is not an issue. Similarly, multicollinearity 
is not a problem as the determinant value $=.018$ which is greater than the required minimum value of .00001

(Tabachnick \& Fidell, 2007). The Kaiser-Meyer-Olkin Measure of Sampling Adequacy is .779 suggesting that the factor analysis yielded distinct and reliable factors. Bartlett's Test of Sphericity is significant $\left(x^{2}=1751.9, p<0.001\right)$ which also supports that factor analysis is an appropriate analysis for this data (Field, 2008). Table 10 summarizes the CSI-B sub-scales that comprise each of the four factors identified by the factor analysis.

Table 10

CSI-B Scales Included in Factors

CSI-B Su Scale

Factor

\begin{tabular}{ll} 
Receptivity to Academic Assistance & One \\
Receptivity to Personal Counseling & One \\
Receptivity to Social Enrichment & One \\
Receptivity to Financial Guidance & One \\
Receptivity to Career Planning & One \\
Desire to finish & Two \\
Attitude towards Educators & Two \\
Family emotional support & Two \\
\hline
\end{tabular}


Table 10 (continued)

CSI-B Sub Scale Factor

Sense of financial security Two

Opinion Tolerance Two

Career Closure $\quad$ Two

Study Habits Three

Intellectual Interests Three

Verbal Confidence Three

Sociability $\quad$ Four

Math / Science Confidence Four

The next step in the analysis of strand one data was the completion of a discriminant analysis. The goal of discriminant analysis is to predict group membership from single or multiple variables (Tabachnick \& Fidell, 2007) Two discriminant analyses were completed. The first focused on the CSI-B composite scales generated by the instrument. The second DA focused on the individual scales included in the four factors that were identified by the previously discussed factor analysis and summarized in Table 10.

The CSI-B generates four composite scales: (a) Dropout proneness, (b) Predicted academic difficulty, (c) Educational Stress, and (d) Receptivity to Institutional 
help. The dropout proneness scale measures the student's overall inclination to drop out of college before finishing their program of study. The scale was developed empirically by comparing students who dropped out from school after their first term with those that continued their studies. The predicted academic difficulty scale was developed by correlating CSI questions with first term college grade point average. Predictors of academic difficulty included in the scale are student's study habits, academic confidence, desire to finish college, attitude toward educators, openness, and high school grade point average. The educational stress scale indicates the student's susceptibility to anxiety, discouragement, and feelings of inadequacy regarding their school experience. Questions on student's academic confidence, attitude toward educators, self-reliance, sociability, leadership, ease of transition, family emotional support, and sense of financial security are combined to estimate the student's level of stress. Finally, the receptivity to institutional help scale estimates how responsive the student is likely to be to institutional intervention. The higher the score, the more receptive the student is to assistance. The scale is based on questions where the student indicates how strongly the 
student desires assistance in a variety of areas including career counseling, personal counseling, social enrichment, and academic assistance. These composite scales are constructed from the 91 non-demographic questions included in the CSI-B.

The grouping variable used in the discriminant analysis was whether or not the student persisted into a second successive course session. The independent variables (the composite scales) were entered into the analysis together and descriptive statistics generated. Box's Test of Equality of covariance was calculated to test whether or not the data differed significantly from the multivariate normal distribution. The results $(F(1,575413)=.254, p=$ $.614)$ indicates that the distribution did not significantly differ from normal and that equal variances can be assumed. Finally, because Box's Test revealed that equal variances could be assumed, Wilks' Lambda was calculated. Wilks' Lambda measures the proportion of total variance in the discriminant scores not explained by differences among groups. Wilks' Lambda for the dropout proneness composite scale was calculated at $(F(1,443)=20.3, p=.000)$. The Wilks's Lambda criteria indicate that the dropout proneness composite scale significantly differentiated students who 
persisted from those that dropped out. Students were more likely to drop out when their dropout proneness composite score was high. Similarly, Wilks' Lambda for the academic difficulty composite score $(F(1,443)=5.34, p=.021)$ also indicated that this composite scale effectively discriminated between students who persisted from those who dropped out. The higher the expected academic difficulty, the more likely it was that a student was going to drop out. Wilks' Lambda criteria for all four composite scales are summarized in Table 11.

Table 11

Tests of Equality of Group Means

\begin{tabular}{|c|c|c|c|c|c|}
\hline $\begin{array}{l}\text { Composite } \\
\text { Scale }\end{array}$ & $\begin{array}{l}\text { Wilks' } \\
\text { Lambda }\end{array}$ & $F$ & $d f 1$ & $d f 2$ & $p$ \\
\hline \multicolumn{6}{|l|}{ Dropout } \\
\hline Proneness & .956 & 20.3 & 1 & 443 & .000 \\
\hline \multicolumn{6}{|l|}{ Educational } \\
\hline Stress & .994 & 2.63 & 1 & 443 & .106 \\
\hline \multicolumn{6}{|l|}{ Academic } \\
\hline Difficulty & .988 & 5.34 & 1 & 443 & .021 \\
\hline $\begin{array}{l}\text { Receptivity } \\
\text { to help }\end{array}$ & 1.00 & .127 & 1 & 443 & .722 \\
\hline
\end{tabular}

The next step in the analysis was to complete a discriminant analysis on the subscales generated by the 
CSI-B. The subscales that were included were only those that comprised the four factors that were identified in the Factor Analysis (see Table 9). Other subscales of the CSI-B were not included in the discriminant analysis.

The grouping variable was whether or not the student persisted into a second successive course session. The independent variables (the sub-scales) were entered in the analysis together, and descriptive statistics generated. Three of the sub-scales, (1) attitude towards educators $(F(1,443)=4.951, p=.027) ;(2)$ sense of financial security $(F(1,443)=8.493, p=.004) ;$ and (7) verbal confidence $(F(1,443)=4.734, p=.030)$ indicated significant group differences between students who persisted from those who dropped out. Students who had more positive feelings towards their teachers and institutional staff were more likely to persist into a second session than were those who have more negative feelings. Similarly, students who reported a stronger sense of financial security surrounding how they were going to pay or finance their education were more likely to persist than those students who felt less secure about their financial situation. Finally, students who reported a stronger sense of confidence in their verbal skills were also more likely 
to persist into a second session of classes. None of the other sub-scales effectively discriminated between students who persisted from those who dropped out. The results of the analysis are summarized in Table 12 .

Table 12

Tests of Equality of Group Means

\begin{tabular}{|c|c|c|c|c|c|}
\hline Subscale & $\begin{array}{l}\text { Wilks' } \\
\text { Lambda }\end{array}$ & $F$ & $d f 1$ & $d f 2$ & $p$ \\
\hline \multicolumn{6}{|l|}{ Financial } \\
\hline Security & .981 & 8.493 & 1 & 443 & .004 \\
\hline Educator & .989 & 4.951 & 1 & 443 & .027 \\
\hline Verbal Conf & .989 & 4.734 & 1 & 443 & .030 \\
\hline Career & .995 & 2.126 & 1 & 443 & .146 \\
\hline Sociability & .996 & 1.805 & 1 & 443 & .180 \\
\hline Vocational & .996 & 1.556 & 1 & 443 & .213 \\
\hline Opinion Tolerance & .998 & 1.109 & 1 & 443 & .293 \\
\hline Finish & .998 & 1.049 & 1 & 443 & .306 \\
\hline Intellectual & .998 & .980 & 1 & 443 & .323 \\
\hline study Habit & .998 & .843 & 1 & 443 & .359 \\
\hline Family support & .999 & .582 & 1 & 443 & .446 \\
\hline Personal & .999 & .523 & 1 & 443 & .470 \\
\hline Financial & .999 & .403 & 1 & 443 & .526 \\
\hline
\end{tabular}


Table 12 (continued)

\begin{tabular}{lccccc}
\hline Subscale & $\begin{array}{l}\text { Wilks' } \\
\text { Lambda }\end{array}$ & $F$ & df1 & df2 & $p$ \\
\hline Math/Science & .999 & .344 & 1 & 443 & .558 \\
Academic Skill & .999 & .229 & 1 & 443 & .632 \\
Social Enrichment & 1.000 & .034 & 1 & 443 & .854 \\
\hline
\end{tabular}

Box's Test of Equality of Covariance was calculated to test whether or not the data did not differ significantly from the multivariate normal distribution. The results $(F(136,566473)=1.09, p=.223)$ indicate that the data was not significantly different. An eigenvalue of .61 was calculated with a canonical correlation of .239. This suggests that the function is not a strong discriminator. Finally, Wilks' Lambda was calculated at .943 with $p=.05$ suggesting that group means differed.

A second run of this analysis was completed. In addition to the CSI-B subscales that were included in the first run, the nine demographic variables previously discussed were introduced to the DA. Two of these variables proved to be significant, (a) the participant's gender $(F(1,443)=6.134, p=.014)$ and (b) the number of hours a 
student planned to work while enrolled in $\operatorname{school}(F(1,443)$

$=8.725, p=.003)$. Males were found to have a higher

propensity to drop out when compared to females. When the

student planned to work more hours while they were in

school also proved to be a significant predictor that a

student might drop out of school. The results of the

discriminant analysis are summarized in Table 13.

Table 13

Tests of Equality of Group Means

\begin{tabular}{|c|c|c|c|c|c|}
\hline $\begin{array}{l}\text { Composite } \\
\text { Scale }\end{array}$ & $\begin{array}{l}\text { Wilks' } \\
\text { Lambda }\end{array}$ & $F$ & $d f 1$ & $d f 2$ & $p$ \\
\hline \multicolumn{6}{|l|}{ Financial } \\
\hline Security & .981 & 8.493 & 1 & 443 & .004 \\
\hline Educator & .989 & 4.951 & 1 & 443 & .027 \\
\hline Verbal Conf & .989 & 4.734 & 1 & 443 & .030 \\
\hline Career & .995 & 2.126 & 1 & 443 & .146 \\
\hline Sociability & .996 & 1.805 & 1 & 443 & .180 \\
\hline Vocational & .996 & 1.556 & 1 & 443 & .213 \\
\hline Opinion Tolerance & .998 & 1.109 & 1 & 443 & .293 \\
\hline Finish & .998 & 1.049 & 1 & 443 & .306 \\
\hline Intellectual & .998 & .980 & 1 & 443 & .323 \\
\hline
\end{tabular}


Table 13 (continued)

\begin{tabular}{|c|c|c|c|c|c|}
\hline $\begin{array}{l}\text { Composite } \\
\text { Scale }\end{array}$ & $\begin{array}{l}\text { Wilks' } \\
\text { Lambda }\end{array}$ & $F$ & $d f 1$ & $d f 2$ & $p$ \\
\hline study Habit & .998 & .843 & 1 & 443 & .359 \\
\hline Family Support & .999 & .582 & 1 & 443 & .446 \\
\hline Personal & .999 & .523 & 1 & 443 & .470 \\
\hline Financial & .999 & .403 & 1 & 443 & .526 \\
\hline Math/Science & .999 & .344 & 1 & 443 & .558 \\
\hline Academic Skill & .999 & .229 & 1 & 443 & .632 \\
\hline Social Enrichment & 1.000 & .034 & 1 & 443 & .854 \\
\hline Workload & .981 & 8.725 & 1 & 443 & .003 \\
\hline Gender & .986 & 6.134 & 1 & 443 & .014 \\
\hline Mother's Education & .997 & 1.168 & 1 & 443 & .280 \\
\hline Racial Origin & .998 & .961 & 1 & 443 & .328 \\
\hline Senior GPA & .998 & .856 & 1 & 443 & .355 \\
\hline Decision to Apply & .999 & .297 & 1 & 443 & .586 \\
\hline Degree Sought & 1.000 & .144 & 1 & 443 & .705 \\
\hline Father's Education & 1.000 & .095 & 1 & 443 & .758 \\
\hline Age & 1.000 & .069 & 1 & 443 & .794 \\
\hline
\end{tabular}

Box's Test of Equality of Covariance was calculated to test whether or not the data differed significantly from the multivariate normal distribution. The results ( $F(10$, 
$869900)=.223, p=.994)$ indicate that the data were not significantly different. An eigenvalue of .84 was calculated with a canonical correlation of .279. This suggests that the function is not a strong discriminator. Finally, Wilks' Lambda was calculated. Wilks' Lambda was calculated at .922 with $p=.000$ suggesting that group means differed.

\section{Summary of strand One Data Analysis}

The data collected with the CSI-B were analyzed to answer the research question driving this study. Seven predictors were found to significantly differentiate between those students who persisted into a second session of classes from those who dropped out. First, students who possessed positive feelings and attitudes toward their faculty and institutional staff with whom they engaged were more likely to persist than those who held less positive or negative attitudes. Second, the stronger a student felt about his or her financial security, the more likely that the student would persist. Third, students with a stronger sense of verbal confidence were more likely to persist than those students who did not feel as confident about their verbal communication skills. Fourth, if students entered college feeling that they were likely to 
drop out at some point, this often became a self-fulfilling prophecy as they were more likely to drop out after their first session. Fifth, students who predicted that they would have academic difficulty during their college tenure were more likely to not persist. Sixth, the more hours a student planned to work while they were attending school, the more likely they were to drop out from classes. Finally, males were more likely to drop out after one session as were those students who reported that they would be working while attending college.

\section{Strand Two}

In an effort to provide additional insight into what factors might differentiate students who persist from those who drop out, 113 of the 445 participants were given an additional questionnaire that asked them about their feelings, beliefs, and intentions towards college. The questionnaire was based on the Theory of Planned Behavior (TPB) and was developed using the guidelines published by Azjen (2006). TPB states that behavioral intentions are the main drivers of behavior and has been a useful tool for predicting a wide range of behaviors (Ajzen, 1991). A copy of the questionnaire is attached in Appendix B. 
An exploratory factor analysis was performed using principal component analysis with varimax rotation to validate that the questionnaire was an effective tool for this population. The results of the factor analysis did not support using the constructs that have been identified previously in the literature (Azjen, 2006). Using the principal component analysis extraction method with varimax rotations, six factors with eigenvalues greater than 2 were generated and these factors accounted for $55.8 \%$ of the variance after rotation. These factors are summarized in Table 14 .

Table 14

Results of Factor Analysis

Initial Eigenvalues

Component Total of Variance Cumulative\%

\begin{tabular}{llrl}
\hline 1 & 8.290 & 20.726 & 20.726 \\
2 & 3.570 & 8.924 & 29.650 \\
4 & 3.117 & 7.791 & 37.441 \\
5 & 2.927 & 7.316 & 44.758 \\
6 & 2.378 & 5.944 & 50.702 \\
\hline
\end{tabular}


The design of the questionnaire allows the researcher to compute three composite scales from the survey questions. These composite scales measure the respondent's attitude about the behavior being investigated, the subjective norms surrounding the behavior, and the perceived control that the respondent feels that they have over the behavior.

A discriminant analysis was completed for the scales suggested by the factor analysis. Although the FA did not provide support for using the three composite scores suggested by the TPB literature, the researcher completed a discriminant analysis using the three composite scores with persistence into a second session serving as the grouping variable. Neither the scales based on the FA nor the composite scores suggested by the literature were found to be significant discriminators between groups. Thus, at least for this research sample, the Theory of Planned Behavior scale scores did not prove to be an effective discriminator between students who persisted into a second session of study from those who dropped out. The results of the discriminant analysis are summarized in Table 15. 
Table 15

Theory of Planned Behavior Questionnaire

\begin{tabular}{|c|c|c|c|c|c|}
\hline Scale & $\begin{array}{l}\text { Wilks' } \\
\text { Lambda }\end{array}$ & $F$ & $d f 1$ & $d f 2$ & $p$ \\
\hline \multicolumn{6}{|l|}{ Factor Scales } \\
\hline Scale one & .994 & .615 & 1 & 111 & .435 \\
\hline Scale two & .998 & .243 & 1 & 111 & .623 \\
\hline Scale three & .997 & .288 & 1 & 111 & .592 \\
\hline Scale four & .993 & .792 & 1 & 11 & .375 \\
\hline Scale five & .990 & 1.115 & 1 & 111 & .293 \\
\hline Scale six & 1.00 & .037 & 1 & 111 & .848 \\
\hline \multicolumn{6}{|l|}{ Literature Scales } \\
\hline Attitude & .992 & .908 & 1 & 111 & .343 \\
\hline Subjective Norm & .997 & .321 & 1 & 111 & .572 \\
\hline Perceived Control & .999 & .101 & 1 & 443 & .751 \\
\hline
\end{tabular}

\section{Strand Three}

Finally, a semi-structured interview guide was developed to provide additional insights and evidence that would help answer the research question posed in this study: What factors differentiate students who persist into their second session of study from those who drop out? During the interviews, participants' experiences during 
their first session of school were explored. Interviews were recorded and transcribed. An open coding thematic analysis method was used to analyze the interviews (Creswell, 2003) with the resulting codes grouped into major themes.

Eight students who had continued into a second session of study participated in the interviews. Although approached several times, no students who had dropped out or elected not to continue into a second session volunteered to participate in the interviews. A number of outreach methods were utilized in this effort including letters, e-mails, and phone calls. None proved successful. Demographic data of the interview participants is summarized in Table 16.

Table 16

Summary of Participant Profiles

\begin{tabular}{lll}
\hline Pseudonym & Age & Ethnicity \\
\hline Will & 36 & African American \\
Maria & 23 & Hispanic (Colombia) \\
Arthur & 22 & Hispanic (Cuba) \\
Juan Carlos & 22 & Hispanic (Puerto Rico) \\
Martha & 18 & Hispanic (Dom Republic) \\
& & \\
\end{tabular}


Table 16 (continued)

Summary of Participant Profiles

\begin{tabular}{lll}
\hline Pseudonym & Age & Ethnicity \\
\hline Julio & 20 & Hispanic (Cuba) \\
Maritza & 21 & Hispanic (Honduras) \\
Carmen & 20 & Hispanic (Nicaragua) \\
\hline
\end{tabular}

\section{Participant Profiles}

will. Will, a 36-year-old African American male is a bachelor's degree student majoring in computer information systems. Will had previously attended college when he was younger but had to stop because of family difficulties. Will is the youngest sibling in a family of three. None of his siblings or parents had attended college. His parents had worked in the retail and transportation industries and were deceased.

Maria. A 23-year-old female, Maria is a bachelor's degree student majoring in business administration. Maria's parents emigrated from Colombia, but she was born in the United states. Maria has a younger sister who is a sophomore in high school. Maria's mother had taken some courses at Miami Dade College. Both parents had completed their high school education in Colombia. Maria had not 
attended college before beginning her studies at DeVry. Maria's parents owned and operated a restaurant in Miami.

Arthur. A native Floridian whose grandparents and father were from Cuba, Arthur, 22, is a first time associate's degree student majoring in Network Systems Administration. Arthur's father was born in Cuba but immigrated to the United States when he was 6 and was raised in Massachusetts. His mother is not of Hispanic descent and was born and raised in Georgia. Arthur's father attended but did not graduate from college while his mother graduated with a bachelor's degree. Arthur's parents operated the family's retail business.

Juan Carlos. Born in Puerto Rico, 22-year-old Juan Carlos was attending college for the first time and was enrolled in the bachelor's degree program in Computer Information Systems. His parents divorced when he was 10 , and Juan Carlos lives with his mother and aunt in Miami. His father lives in Puerto Rico. Juan Carlos is the first individual from his family to attend college.

Martha. Martha, 18 years old, was born in New Jersey. Her parents are from the Dominican Republic and have lived in the United States for over 20 years. Martha is also of African descent. A first time college student, Martha is a 
bachelor's degree student majoring in Business Administration. She has a younger sister and is the first in her family to attend college.

Julio. A business administration major, 20-year-old Julio was born in the United States. Julio's family was from Cuba, and he lived with his mother, an older sister and his grandparents. His father had passed away while he was a junior in high school. His mother was a medical office assistant but had not attended college. Julio was attending college for the first time.

Maritza. The oldest of six children who were born in Guatemala but raised in the United States, Maritza had just turned 21 when she participated in the interview. Maritza was attending college for the first time and was majoring in business administration. Maritza's parents both worked in the retail industry and had not attended college.

Carmen. Born in Nicaragua, Carmen is the youngest of three siblings, both of whom had previously dropped out of college. She is majoring in Business Administration and is 20 years old. This is her first attempt at college. Her parents never attended college and both work in the banking field in clerical support jobs. 


\section{Analysis of Themes}

The data generated during this phase of the study were analyzed by using a process detailed by Creswell (2003). First the data were organized and transcribed. After this was completed, the data analysis began. A preliminary exploratory analysis was completed. This step consisted of exploring and reading the data by the researcher so that a general feel for the data could be developed. A qualitative codebook was developed next. After the codebook was developed, the researcher recorded a list of statements from the transcripts. The next step in the data analysis was to begin the coding process. Each statement was coded and given a corresponding label. Next, an inductive process was initiated where the preliminary codes was grouped and collapsed into sub-themes. These sub-themes were categorized and, where appropriate, layered and interrelated into a smaller set of broader themes.

Two broad themes, positive supports that participants felt helped them stay in school and concerns that participants felt could threaten their persistence, emerged from an analysis of the interviews. First, college represented a new and different educational experience for all participants. Charlie (an alias), a first time in 
college Hispanic male, stated that his first session was "very hectic and full of new experiences for him." Charlie "knew that college would be hard from the get go" and that "he would need a lot of perseverance." These feelings were echoed by all of the interviewees.

All of the participants reported that they had felt positive about their first session in college. A number reported feeling a sense of accomplishment and pride in completing their first college classes. Will, an African American male who had dropped out from a community college in his previous attempt to attend college, noted that he felt "good about himself and that his father would be proud of me."

When asked about the process that had led them to decide to attend college all interviewees responded that they had always wanted to attend college but felt that they might not be able to because of family issues. All participants reported that their prior educational experiences had not inspired them to succeed academically. DeVry's active learning philosophy resonated with the participants as all mentioned that the ability to apply the theories they were learning kept them engaged and motivated. 
By far the largest concerns that the participants had was how they were going to pay for school and how they would balance school with work and family. All interviewees noted that even after their first session they were still learning how to balance the demands of school and life. All reported that they felt comfortable with their ability to handle the academic demands that they faced.

Participants were asked about supports that they had utilized during their stay in college. They reported that they relied on faculty and university staff to help them navigate the challenges they faced. In particular, the important role of the faculty was underscored by all of the participants. Will stated that the "faculty were most helpful and were always willing to listen." A high level of expertise and credibility was ascribed to faculty. Will noted that "I listen to them because they have accomplished things in their lives-they have done what I want to do, so I seek them out and listen to them."

Finally, six of the eight interview participants noted that their lack of knowledge about college was the major barrier that they had encountered during their first session. Several noted that they did not know many people at the beginning and that "they were pretty much on their 
own." All participants noted that while they all had the support of their families, few members of their family had experience with college. When asked what they would recommend that a student do that would help them stay in school, four out of the six answered with an answer that focused on asking questions or seeking out information.

\section{Summary}

This study examined factors that differentiated forprofit college students who persisted into a second session of study from those who dropped out. Three strands of data were collected during the study. Discriminant function analysis was used as the method to identify differentiating variables in the quantitative strands and thematic analysis was used to analyze the interview data collected in the quantitative strand.

Seven significant findings were generated by the analysis of the data collected in strand One. Two composite scores, dropout proneness, and predicted academic difficulty generated by the college student Inventory-Form B proved to be significant. In addition, several of the scales generated by the CSI-B proved to be significant. Attitudes toward educators, sense of financial security, and verbal confidence differentiated those who persisted in 
their studies from those who dropped out. Finally, two demographic variables, gender and employment workload, also proved to differentiate between those students who persisted from those who did not.

Analysis of the data collected during strand Two did not yield any significant findings. Finally, two broad themes, positive supports that participants felt helped them stay in school and concerns that participants felt could threaten their persistence emerged from the interview data collected during strand Three. First all of the interviewees noted that college was a new and different experience and could present a challenge to some. A second concern that participants identified was that financial challenges were the most likely issue that they felt would impede their success in college. Related to this concern was the feeling that balancing the demands of college with the demands of their lives (e.g., work and family)was challenging. A lack of knowledge about how colleges operate was concern that was identified and cited as being the most significant barrier faced by students. Finally, participants identified that college staff and faculty support were the most significant supports that helped them succeed during their first session in college. 
The findings from Strand Three support two of the findings of strand One. First, the financial concerns identified in the interviews support the findings from strand one where students with a low sense of financial security were more likely to drop out when compared to students who possessed a higher sense of financial security. These findings echo previous studies reported in the literature that have found financial issues and concerns to be a significant factor influencing student persistence. It can also be argued that the strong feelings of receptivity to academic assistance, institutional help, and career planning impacted the positive feelings that students had for faculty as sources of information. Faculty were able to tap into this "hunger" for assistance and provide information and guidance to students that likely positively influenced their decision to persist with their studies. Implications for additional research and practice for these areas will be further discussed in the next chapter.

Chapter 5 summarizes the study and discusses the findings. In addition, conclusions based on the results, limitations of the study, and recommendations for further research and practice are presented and discussed. 


\section{CHAPTER V}

\section{Discussion}

This chapter begins with a brief summary of the study followed by a discussion of the findings. Suggestions for future research and recommendations for practice are presented. Limitations of the study that impact the application of these recommendations are also reviewed and discussed.

\section{Summary of the study}

\section{Purpose of the study}

The purpose of this study was to identify those factors that differentiated for-profit college students who persisted into a second session of study from those who dropped out.

\section{Rationale for the study}

Persistence continues to be a significant issue for all colleges and universities. Despite decades of focus, persistence rates have remained stagnant. Growing numbers of students are selecting for-profit institutions to pursue their higher education goals. Although college student persistence has been studied empirically for years, few studies have examined persistence among students who attend for-profit colleges and universities. The studies that have 
focused on for-profit institutions seem to suggest that prior academic preparation, the quality of faculty interactions with students, students commitment to completing their education, and their self-perceived efficacy about their academic skills are important factors that can help determine persistence. However, most of these studies have been marked by methodological weaknesses limiting their utility.

A need exists for research that focuses on the persistence of students who enroll in for-profit colleges and universities and the variables that distinguish between students who persist from those who drop. Identifying those differentiating variables and factors can allow the institution to develop intervention strategies and programs aimed at enhancing student persistence.

\section{Research Question}

The main research question posed in this study was: What factors differentiate students who persist into their second session of study from those who drop out?

\section{Methods}

A mixed methods research design consisting of three strands was utilized. Undergraduate students at DeVry University-South Florida comprised the population that was 
examined. Their self-reported perceptions of what their college experience would be like, as well as demographic information were collected during Strands 1 and 2. The third strand utilized a predominantly qualitative approach with a purposeful sample for maximal variation emerging from the results of the earlier strands. Semi-structured, funnel-sequenced interviews were utilized during this strand.

\section{Results}

Seven significant findings were generated by the analysis of the data collected in strand One. Two composite scores, dropout proneness and predicted academic difficulty generated by the College Student Inventory-Form B, proved to be significant. In addition, several of the scales generated by the CSI-B proved to be significant. Attitudes toward educators, sense of financial security, and verbal confidence differentiated those who persisted in their studies from those who dropped out. Finally, two demographic variables, gender and employment workload, also proved to differentiate between those students who persisted from those who did not.

Analysis of the data collected during strand Two did not yield any significant findings. Finally, several themes 
emerged from the interview data collected during strand Three. Participants noted that financial concerns were issues that they felt would impede their success in college. A second concern was how they would balance the demands of college with the demands of their lives. A lack of knowledge about how colleges operate was cited as another barrier faced by students. College staff and faculty support were reported to be the most significant supports reported by those interviewed.

The data generated by this study support and augment existing literature. First, while considerably more at risk than traditional students, it can be argued that students who attend for-profit institutions react to the challenges of college in much the same way as students who attend private, not for-profit, or state funded institutions. Ethnic minority males in the research sample were more likely to drop out than ethnic minority females, mirroring findings of studies that focused on non-profit institutions. Students who work more than 20 hours a week are more likely to drop out than students who work fewer hours. This finding supports findings in the non-profit literature. Students in the research sample were concerned with the financial aspects of their education. Numerous 
studies have found that this is the case across all types of universities and colleges. Students are concerned about their academic preparation and how difficult they believe college will be for them. Finally, despite their perceived and real challenges, students attending for-profit institutions look to the faculty, staff, and the institution for assistance and guidance.

\section{Recommendations for Future Research}

As for-profit institutions continue to attract students and evolve, additional research studies focusing on both the behaviors exhibited by students who attend these institutions as well as the overall student experience they encounter are needed. Most of the limited literature that exists to date focuses on a single location or single institution. As a significant number of students who attend for-profit institutions attend multi-campus systems, additional studies examining the student experience at different locations within these large systems is warranted. In addition, there are many types of for-profit institutions. Research studies that focus on different types of institutions and on comparing student behavior across institutional types and degree programs are also needed. 
The vast majority of research attention on persistence has focused on student characteristics that influence whether a student achieves the ultimate goal of graduation. Little attention has been paid to the institutional factors and practices that contribute to success in student persistence (Braxton, 2009). Continued weak retention and graduation rates have prompted many to realize that existing institutional activities and practices designed to mitigate student drop-out rates are ineffective and in need of enhancement and improvement (Braxton, 2009).

Recently, that focus has begun to change and leading researchers in the field have called for greater attention to institutional practice. Vincent Tinto (2006-2007), the pre-eminent persistence scholar during the past 25 years, has noted that colleges and universities have failed to transfer their knowledge and understanding of persistence in higher education into institutional programs and practices that have resulted in positive gains in persistence and graduation rates. Braxton and Hirschy (2005) have argued that colleges and universities need to establish a scholarship of practice to improve institutional practices aimed at increasing student 
persistence and to develop a knowledge repository supporting these effective institutional practices.

Finally, this study suggests that for students who attend for-profit institutions, faculty members may play an influential and potentially critical role in enhancing persistence. Further research investigating this relationship and what training and support for faculty are needed is warranted. As seen in the research sample, forprofit students fit the description of non-traditional students identified in the literature. Non-traditional students attend many institutions, and research into the faculty/student relationship with respect to student persistence has applicability throughout higher education.

\section{Implications for Practice}

Researchers have noted that the initial classroom experiences that students receive have a strong influence on whether they remain or depart their college or university (Erikson, Peters, \& Strommer, 2006; Giaquinto, 2009). The students in this research sample indicated that they were very receptive to assistance and guidance about a number of factors related to the college experience. Students also suggested that they valued and respected faculty 
This study suggests that for many students, faculty members can serve as a key source of information and influence that can enhance the likelihood that the student will persist. Programs aimed at developing or enhancing faculty skills that could be used to help first year students is an area that needs further study, development and implementation. For example, Giaquinto (2009) notes that first year students need assistance with the transition from high school to college; overcoming the challenges of college work; and they lack the familiarity with the resources on campus in addition with many other potential obstacles. It should not be expected that faculty and staff are skilled in these areas and can effectively assist students with these issues. Training for faculty in these areas could be an important component of any institutional persistence program.

Likewise, a student's academic and social integration into a university community can be strongly influenced by having an advisor or mentor (Tinto, 1993). The data from this study suggests that students have a strong desire to acquire information and assistance about all aspects of their college experience. Faculty mentoring programs have been found to increase student retention and graduation 
rates (Campbell \& Campbell, 1997). Karp, Hughes, and O'Gara (2010) have put forth the notion of "information networks" which they define as the social ties that allow the student to learn institutional procedures and practices. The investigators reported on the relationships between faculty members who teach student success courses at two urban community colleges in the Northeast. Students in the study reported that they saw their faculty member as a resource for guidance and support even after the student success course ended. Brier, Hirschy, and Braxton (2008) report on an administrative practice implemented within the college of Education at Vanderbilt University. The program, called the Strategic Retention Initiative (SRI), focuses on first year students who as noted in the literature are at the greatest risk of dropping out as they begin their university studies. The dean of students is charged with calling each new student during the initial stages of each fall semester and then again in the spring semester. The brief call focuses on the student's experiences at the university and asks the student about their academic and social transitions as well as the types of activities, organizations, and services in which they are involved. Depending on the student responses, the dean may make 
referrals, offer encouragement, or schedule a follow-up meeting for additional assistance. While noting that they cannot prove causality, the authors report that first to second year retention has increased from $88 \%$ to $95 \%$. Training programs aimed at helping faculty develop these skills need increased development and implementation.

As supported by the findings of this study, faculty mentoring may be an especially effective tool for minority students. A number of studies have found that Hispanic students who have a mentor are more likely to persist (Bordes \& Arredondo, 2005; Torres \& Hernandez, 2009). Torres, Reiser, LePeau, Davis, and Ruder (2006) reported that many Hispanic students lack information that enables them to navigate the college environment successfully and do not know when they should ask questions or seek additional information. These programs should not be limited to faculty and should also be offered to all university staff that interacts with students.

Implications for changes and enhancement in practice for DeVry University are suggested by the findings of this study. First, programs that focus on students who score high on the dropout proneness scale should be developed and implemented. Second, support programs should be enhanced 
and delivered to students who feel that they will have significant academic difficulties. Building on the receptivity that students report they have for guidance and information focusing on academic assistance and career planning, the institution should develop and implement outreach programs that can be proactively offered to all students. Third, programs focusing on financial security and literacy need to be implemented. These programs should include components that identify options for students that will allow them to work fewer hours while they are enrolled in school. Fourth, outreach efforts aimed at male students need to be developed and implemented. Fifth, the continued use of the CSI-B in its current form should be reviewed and analyzed for effectiveness. Other available alternatives including the development of a DeVry specific instrument should be considered. Finally, and perhaps most important, faculty development and training programs that support the role of faculty as the key link for delivering the information about programs detailed above should be a priority for the institution.

\section{Limitations}

A limitation of this study was the lack of interviews completed with individuals who dropped out from school. 
Although several attempts were made to contact these individuals and modifications to the recruitment process made, the researcher was unable to secure any participants who had dropped out. While not an unusual occurrence in research studies focusing on college persistence, this does limit the generalization of the results.

\section{Summary}

The purpose of this study was to identify those factors that differentiated for-profit college students who persisted into a second session of study from those who dropped out. A mixed methods research design consisting of three strands was utilized. Student's self-reported dropout proneness, predicted academic difficulty, attitudes toward educators, sense of financial security, and verbal confidence differentiated those who persisted in their studies from those who dropped out. Two demographic variables, gender and number of hours worked while enrolled in school, also proved to differentiate between those students who persisted from those who did not. Several themes emerged from the interview data collected. Participants noted that financial concerns were the biggest issues that they felt would impede their success in college. A second concern was how they would balance the 
demands of college with the demands of their lives. A lack of knowledge about how colleges operate was cited as another barrier faced by students. College staff and faculty support were reported to be the most significant supports reported by those interviewed. 


\section{REFERENCES}

Ajzen, I. (1985). From intentions to actions: A theory of planned behavior. In J. Kuhl \& J Beckman, (Eds), Action control: From cognition to behavior (pp. 57$73)$. Berlin: Springer-Verlag .

Ajzen, I. (1991). The theory of planned behavior. Organizational Behavior and Human Decision Processes, 50, 179-211.

Ajzen, I. (2006). Constructing a TpB questionnaire: conceptual and methodological considerations. Retrieved from http://www.people.umass.edu/ajzen

Allen, D. (1997, September). The hunger factor in student retention: An analysis of motivation. Paper presented at the annual forum of the Association for Institutional Research, 37th Annual Meeting, Orlando, Florida.

American College Testing Program. (2009). National collegiate retention and persistence to degree rates. Retrieved from http://www.act.org

America loses ground in college access, participation, study finds. (2003, October 23). Black Issues in Higher Education, p.1.

Arbonna, C., \& Novy, D. M. (1990). Non-cognitive dimensions as predictors of college success among Black, MexicanAmerican, and White students. Journal of College Student Development, 31, 415-422.

Astin, A. W. (1984) Student involvement: A developmental theory for higher education. Journal of College student Personnel, 25, 297-308.

Basha, V., \& Lunenburg, F. C. (2001, March). Usefulness of the college student inventory as a needs assessment tool in community colleges. Paper presented at the Annual Meeting of the National Council of Professors of Educational Administration, Houston, Texas.

Baughman, L.C. (1997). Self-efficacy and selected variables as predictors of persistence for first quarter 
students at a proprietary institution. Available from ProQuest Dissertations and Theses database.

(Publication Number: AAT 9801362)

Bean, J. P. (1980). Dropouts and turnover: The synthesis and test of a causal model of student attrition. Research in Higher Education, 12, 155-187.

Bean, J. P., \& Eaton, S. B. (2000). A psychological model of college student retention. In J. M. Braxton (Ed.), Reworking the student departure puzzle (pp. 48-61). Nashville, TN: Vanderbilt University Press.

Bean, J. P., \& Metzner, B. S. (1985). A conceptual model of nontraditional student attrition. Review of Educational Research, 55, 485-540.

Berger, J. B., \& Braxton, J. M. (1998). Revising Tinto's interactionalist theory of student departure through theory elaboration: Examining the role of organizational attributes in the persistence process. Research in Higher Education, 39, 103-119.

Berger, J. B., \& Lyon, S. C. (2005). Past to present: A historical look at retention. In A. Seidman (Ed.), college student retention: Formula for student success (pp. 1-31). Westport, CT: Greenwood Publishing.

Berger, J. B., \& Milem, J. F. (1999). The role of student involvement and perceptions of integration in a causal model of student persistence. Research in Higher Education, 40, 641-664.

Boggs, R. J. (2007). Do they stay? A retention study of a for-profit university. Available from ProQuest Dissertations and Theses database. (Publication Number: AAT 3273903)

Bordes, V., \& Arredondo, P. (2005). Mentoring and $1^{\text {st }}$-year Latina/o college students. Journal of Hispanic Higher Education, 4, 114-133.

Bowen, H. (1977). Investment in learning: The individual and social value of American higher education. San Francisco, CA: Jossey-Bass. 
Braxton, J. M. (Ed.) (2000). Reworking the student departure puzzle. Nashville, TN: Vanderbilt University.

Braxton, J. M. (2003). Persistence as an essential gateway to student success. In $S$. Komives \& D. Woodard (Eds.), Student services: A handbook for the profession (4th ed.; pp. 317-335). San Francisco, CA: Jossey-Bass.

Braxton, J. M. (2009). Catalysts and constraints to college student persistence: Introduction to a special issue of the Journal of College Student Retention: Research, Theory and Practice. Journal of College Student Retention, 11, 1-5.

Braxton, J. M., \& Hirschy, A. S. (2005). Theoretical developments in college student departure. In A. Seidman (Ed.), College student retention: Formula for student success (pp. 61-87). Westport, CT: Greenwood Publishing.

Braxton, J. M., Hirschy, A. S., \& McClendon, S. A. (2004). Understanding and reducing college student departure. ASHE-ERIC Higher Education Reports, 30, 1-97.

Braxton, J. M., \& Lee, S. D. (2005). Toward reliable knowledge about college student departure. In A. Seidman (Ed.), College student retention: Formula for student success, (pp. 107-127). Westport, CT: Greenwood Publishing.

Braxton, J. M., Sullivan, A. S., \& Johnson, R. M. Jr. (1997). Appraising Tinto's theory of college student departure. In J. Smart (Ed.), Higher education: Handbook of theory and research (Vol. 12, pp.107-164). New York, NY: Agathon Press.

Brier, E., Hirschy, A. S. \& Braxton, J. M. (2008). The strategic retention initiative: Theory based practice to reduce college student departure. About Campus, 13, $18-20$.

Browning, C. (2000). An analysis of student motivations for withdrawal in a community college. Journal of Applied Research in the Community College, 4, 5-21. 
Butner, G., Carter, S., \& Brown, P. (2004). The undergraduate Hispanic experience. Journal of College Student Development, 41, 135-145.

Cabrera, A. F., Nora, A., \& Castenada, M. B. (1994). The role of finances in the persistence process: A structural model. Research in Higher Education, 33, 571-593.

Campbell, T. A., \& Campbell, D. E. (1997). Faculty/student mentoring program: Effects on academic performance and retention. Research in Higher Education, 38, 727-742.

Chung, A. S. (2008). For-profit colleges: An opportunity for under-served? Available from ProQuest Dissertations and Theses database (Publication number AAT3344568)

Chung, A. S. (2009). For-profit student heterogeneity (Munich Personal RePEC Archive Paper No. 18967). Germany: University Library of Munich.

Clehouse, R. E. (2000). Determining persistence indicators of students enrolled in for-profit postsecondary institutions. Available from ProQuest Dissertations and Theses database (Publication number AAT 9989414)

Cohen, A. M., \& Brawer, F. B. (2003). The American community college (4th ed.). San Francisco, CA: Jossey-Bass.

Cohn, E., \& Geske, T. (1992). Benefit-cost analysis of investment in higher education (Working Papers in Economics). Columbia: University of South Carolina, College of Business Administration, Division of Research.

Council for Adult and Experiential Learning (CAEL). (2000). Serving adult learners in higher education: Principles of effectiveness. Chicago, IL: CAEL.

Creswell, J. W. (2003). Research design: Qualitative, quantitative, and mixed methods approaches. Thousand Oaks, CA: Sage. 
Creswell, J. W., \& Plano Clark, V. L. (2007). Designing and conducting mixed methods research. Thousand Oaks, CA: Sage.

Cubeta, J. F., Travers, N. L., \& Sheckley, B. G. (2000). Predicting the academic success of adults from diverse populations. Journal of College Student Retention, 2, 295-311.

Day, J. C., \& Newburger, E. C. (2002). The big payoff: Educational attainment and synthetic estimates of work life earnings. Washington, DC: U.S. Census Bureau.

Dayton, E. (2005). Factors that influence adult success at community college. The Community College Enterprise, $11,45-60$.

Durkheim, E. (1951). Suicide: A study in sociology (trans. 1897). Glencoe, IL: The Free Press.

Dyer, T. (2006). Selected correlates of student persistence and institutional factors in for-profit art and design colleges. Available from ProQuest Dissertations and Theses database (Publication number: AAT 3234445)

Erikson, B. L., Peters, C. B., \& Strommer, D. W. (2006). Teaching first-year college students: Revised and expanded edition of teaching college freshmen. California: Jossey-Bass.

Fact Book. (2008). A profile of career colleges and universities. Imagine America Foundation. Available at www. imagineamericafoundation.com

Francis, J. J. (2004). Constructing questionnaires based on the theory of planned behavior. Available at www . rebeqi.orgviewfile.aspx? itemID $=212$

Freer-Weiss, D. (2004). Community college freshmen: Last in, first out? Journal of College student Retention, $6,137-154$.

Friedman, B. A., \& Mandel, R. G. (2009). The prediction of college student academic performance and retention: Application of expectancy and goal setting theories. Journal of College Student Retention, 11, 227-246. 
Giaquinto, R. A. (2009). Instructional issues and retention of first-year students. Journal of College student Retention, 11, 267-285.

Graham, S. W., \& Gisi, S. L. (2000). Adult undergraduate students: What role does college involvement play? NASPA Journal, 38, 99-122.

Guarino, A. J., \& Hocevar, D. (2005). Tinto's model and locus of control. College and University, 80, 43-44.

Hawley, T. H., \& Harris, T. A. (2005). Student characteristics related to persistence for first year community college students. Journal of College student Retention, 7, 117-142.

Hernandez, J. C. (2000). Understanding the retention of Latino college students. Journal of College student Development, November/December, 2, 47-57.

Hernandez, J. C., \& Lopez, M. A. (2007). Leaking pipeline: Issues impacting Latino/a college student retention. In A. Seidman (Ed.), Minority student retention: The Best of the Journal of College student Retention (pp. 74-95). Amityville, NY: Baywood Publishing.

Hoffman, J. L., \& Lowitzki, K. E. (2005). Predicting college success with high school grades and test scores: Limitations for minority students. Review of Higher_Education, 28, 455-474.

Hogan, T. P. (2004). Review of the college student inventory. Mental Measurements Yearbook, 16, 199-206.

Howard-Vital, M. (2006). The appeal of for-profit institutions. Change, January/February, 68-71.

Hurtado, S., Gener, B., Ramirez, E.P., \& Mayell, S. (1994). Latino student transition to college: Assessing difficulties and factors in successful college adjustment. New Orleans, LA: AIR Annual Forum.

Johnson, R. B., Onwuegbuzie, A. J., \& Turner, L. A. (2007). Toward a definition of mixed methods research. Journal of Mixed Methods Research, 1, 112-133. 
Karp, M. M., Hughes, K. L., \& O'Gara, L. (2010). An exploration of Tinto's integration framework for community college students. Journal of College student Retention, 12, 69-86

Kelly, K. (2001). The rise of for-profit degree granting institutions: Policy considerations. Denver, CO: Education Commission of the States (ECS).

Kinser, K. (2006). From Main street to Wall street. ASHE Higher Education Report, 31, 1-146.

Kuh, G. D., Kinzie, J. A., Bridges, B. K., \& Hayek, J. C. (2007). Piecing together the student success puzzle. ASHE Higher Education Report, 32, 1-182.

Kuh, G. D., Kinzie, J. A., Schuh, J. H., \& Whitt, E.J. (2005). Student success in college: Creating conditions that matter. San Francisco, CA: Jossey Bass.

Kuh, G. D., \& Love, P. G. (2000). A cultural perspective on student departure. In J. M. Braxton (Ed.), Reworking the student departure puzzle: New theory and research on college student retention (pp. 196-212). Nashville, TN: Vanderbilt University.

Lester, L. G. E. (2004). Effects of coping styles on college persistence decisions among Latino students in two year colleges. Journal of College student Retention, 5, 11-22.

Levesque, K., Laird, J., Hensley, E., Choy, S.P., Cataldi, E.F., \& Hudson, L. (2008). Career and technical education in the United States: 1990 to 2005 (NCES 2008-35). Washington, DC: National Center for Education statistics.

Littleton, P. M. (2001). Persistence of African American college students. Black Issues in Higher Education, $14,24-27$.

Lotkowski, V. A., Robbins, S. B., \& Noeth, R. J. (2004). The role of academic and non-academic factors in improving college retention. ACT Policy Report. 
Retrieved from

http://inpathways.net/college_retention.pdf.

Mason, H. P. (1998). A persistence model for African American male urban community college students. Community College Journal of Research and Practice, $22,751-760$.

McClenney, K. M., \& Waiwaiole, E. N. (2005). Community College Journal, 75, 36-41.

McDaniel, C. \& Graham, S. W. (2001). Student retention in a historically black institution. College student Journal, 35(1), 143-157.

Merisotis, J. (2005). The investment payoff: A 50 state analysis of the public and private benefits of higher education. Institute for Higher Education Policy Retrieved from http: //www. ihep.org/pbs/pdf/investmentpayoff2005.pdf

Merriam, S. B. (1998). Qualitative research and case study applications in education. San Francisco, CA: JosseyBass.

Moman, F. L. (2002). The effects of a mentoring intervention on student retention in a community college. Available from ProQuest Dissertations and Theses database. (Publication number: AAT 3050249)

Moore, R. (2004). Pre-enrollment and post enrollment predictors of the academic success of development education students. Journal of College student Retention, 6, 325-335.

Moore, R., Jensen, M., Hsu, L., \& Hatch, J. (2002). Saving the "false negatives": Intelligence tests, the SAT, and developmental education. In D. B. Lundell \& J. L. Higbee (Eds.), Exploring urban literacy and developmental education (pp. 47-57). Minneapolis, MN: Center for Research on Developmental Education and Urban Literacy, General College, University of Minnesota. 
Naretto, J. A. (1995). Adult student retention: The influence of internal and external communities. NASPA Journal, 32, 90-97.

National Center for Education Statistics. (2002). Special analysis 2002 nontraditional undergraduates. Institute of Education Sciences, United States Department of Education.

National Center for Education Statistics. (2005). Digest of education statistics. Washington, DC: U.S. Department of Education.

National Center for Education Statistics. (2006). Digest of education statistics. Washington, DC: U.S. Department of Education.

National Center for Education Statistics. (2007). Digest of education statistics. Washington, DC: U.S. Department of Education.

Noel Levitz. (2002). College Student Inventory-Form B. Fall 2001 Validity study. Noel Levitz.

Oseguera, L., \& Malagon, M. C. (2011). For-profit colleges and universities and the Latina(o) students who enroll in them. Journal of Hispanic Higher Education, 10, 6691 .

Outtz, J. H. (1995). Higher education and the new demographic reality. Educational Record, 7, 65-69.

Pascarella, E., \& Chapman, D. (1983). A multiinstitutional, path analytic validation of Tinto's model of college withdrawal. American Educational Research Journal, 20, 87-102.

Pascarella, E., Smart, J., \& Ethington, C. (1986). Long term persistence of two-year college students. Research in Higher Education, 24, 47-71.

Pascarella, E., \& Terenzini, P. (1991). How college affects students: Findings and insights from twenty years of research. San Francisco, CA: Jossey-Bass Publishers. 
Pascarella, E., \& Terenzini, P. (2005). How college affects students: Volume 2, a third decade of research. San Francisco, CA: Jossey-Bass Publishers.

Peltier, G. L., Laden, R., \& Matranga, M. (1999). Student persistence in college: A review of research. Journal of College student Retention, 1, 357-376.

Pew Higher Education Roundtable. (1994). Policy perspectives: To dance with change. Retrieved from wWw.pew.org

Phipps, R. A., Harrison, K. V., \& Merisotis, J. P. (2000). Students at private, for-profit institutions (No. NCES 2000-175). Washington, DC: The Institute for Higher Education Policy. U.S. Department of Education.

Piazza, R. M. (1996). A test of Tinto's model of voluntary student departure at a proprietary institution. Available from Proquest Dissertations and Theses database. (Publication number: AAT 9619339)

Pidcock, B. W., Fischer, J. L., \& Munsch, J. (2001). Family, personality, and social risk factors impacting the retention rates of first year Hispanic and Anglo college students. Adolescence, 36, 803-818.

Rendon, L. I. (1983). Validating culturally diverse students. Innovative Higher Education, 19, 33-51.

Rendon, L. I., \& Nora, A. (1994). A synthesis and application of research on Hispanic students' $n$ community colleges. In J. L. Ratcliff, S. Schwartz \& L.H. Ebbers (Eds.), Community colleges (3rd ed., pp 357-369). Needham Heights, MA: Simon \& Schuster.

Ruch, R. S. (2001). Higher Ed, Inc.: The rise of the forprofit university. Baltimore, MD: Johns Hopkins University Press.

Sauchuk, S. B. (2003). A case study of student retention in two programs at a two year for-profit institution of post-secondary education. Available from Proquest Dissertations and Theses database. (Publication Number: AAT 3092048) 
Schartz, T., \& Washington, M. P. (1999). An analysis of African American attrition rates. Urban Education, 27, 59- 79 .

Schreiner, L. (1991). The college student inventory: Accurately identifying students at risk. Iowa City, IA: Noel-Levitz, Inc.

Serra Hagedorn, L., Maxwell, W., \& Hampton, P. (2002). Correlates of retention for African-American males in community colleges. Journal of College student Retention, 3, 243.

Seidman, A. (Ed.), (2007). Minority student retention: The best of the journal of college student retention: Research, theory \& practice. Amityville, NY: Baywood.

Shultz, E. L., Colton, G. M., \& Colton, C. (2001). The adventor program: Advisement and mentoring for students of color in higher education. Journal of Humanistic Counseling, Education and Development, 1, 208-219.

Snyder, T.D., Tan, A.G., \& Hoffman, C.M. Digest of Education Statistics 2005. Technical Report NCES 2006-030, National Center for Education Statistics, U.S. Department of Education, Washington, DC.

Solis, E., Jr. (1995). Regression and path analysis models of Hispanic community college students' intent to persist. Community College Review, 23, 3-15.

Spady, W. (1970). Dropouts from higher education: An interdisciplinary review and synthesis. Interchange, $1,64-85$.

St. John, E. P., Cabrera, A. F., Nora, A., \& Asker, E. H. (2000). Economic Influences on persistence reconsidered: How can finance research inform the reconceptualization of persistence models? In $\mathrm{J}$. Braxton (Ed.), Reworking the student departure puzzle (pp. 98-112). Nashville, TN: Vanderbilt University Press.

Stratil, M. L. (1984). Stratil counseling inventory-College form. Lumberton, NC: Psychological Configurations. 
Stratil, M. L. (1988). College student inventory. Coralville, IA: Noel-Levitz, Inc.

Stratil, M. L. (2001). The RMS research and technical guide. Iowa City, IA: USA Group Noel-Levitz.

Stratil, M. L., Schreiner, L. A., \& Noel, P. (1993). Retention management system coordinator's manual. Iowa City, IA: USA Group Noel-Levitz.

Swail, W. S. (2000). Preparing America's disadvantaged for college: Programs that increase college opportunity. In N. Cabrera, \& S. M. La Nasa (Eds.), Understanding the college choice of disadvantaged students: New directions for institutional research. San Francisco, CA: Jossey-Bass.

Swail, W. S., Redd, K. E., \& Perna, L. W. (2003). Retaining minority students in higher education: A framework for success. ASHE-ERIC Higher Education Reports, 30, 1172 .

Tabachnick, B., \& Fidell, L. (2007). Using multivariate statistics (5th ed.). Boston, MA: Allyn and Bacon.

Tashakkori, A., \& Creswell, J. W. (2007). Editorial: Exploring the nature of research questions in mixed methods research. Journal of Mixed Methods Research, $1,3-7$.

Teddlie, C., \& Tashakkori, A. (2006). A general typology of research designs featuring mixed methods. Research in the Schools, 13, 12-28.

Tierney, W. G., \& Hentschke, G. (2007). New players, different game: Understanding the role of for profit colleges and universities. Baltimore, MD: Johns Hopkins University Press.

Tinto, V. (1975). Dropout from higher education: A theoretical analysis of recent research. Review of Educational Research, 45, 89-125.

Tinto, V. (1986). Theories of student departure revisited. In J. Smart (Ed.), Higher education: A handbook of 
theory and research, Volume 2 (pp. 359-384). New York, NY: Agathon Press.

Tinto, V. (1987). Leaving college: Rethinking the causes and cures of student attrition. Chicago, IL: University of Chicago Press.

Tinto, V. (1993). Leaving college: Rethinking the causes and cures of student attrition (2nd ed.). Chicago, IL: University of Chicago Press.

Tinto, V. (1999). Taking retention seriously: Rethinking the first year of college. NACADA Journal, 19, 5-9.

Tinto, V. (2006-2007). Research and practice of student retention: What's next? Journal of College student Retention: Research, Theory and Practice, 1, 1-19.

Tinto, V. (2007). Rethinking the first year of college. Retrieved from http://www.syracuse.edu/edu/tinto

Torres, V., Gross, J. P., \& Dadashova, A., (2010). Traditional age students becoming at risk: Does working threaten college students' academic success? Journal of College Student Retention, 12, 51-68.

Torres, V., \& Hernandez, E. (2009). Influence of an identified advisor/mentor on urban latino students' college experience. Journal of College student Retention, 11, 141-160.

Torres, V., Reiser, A., LePeau, L., Davis, L., \& Ruder, J (2006). A model of first generation Latino/a college students' approach to seeking academic information. NACADA Journal, 26, 65-70.

Trippi, J., \& Baker, S. (1989). Student and residential correlates of Black student grade performance and persistence at a predominately white university campus. Journal of College student Development, 3, $136-143$.

Ulm, P. (2002). Community college students: Recent findings and trends. Community College Review, 29,77. 
Watson, L., \& Kuh, G. (1996). The influence of dominant race environments on student involvement, perceptions, and educational gains: A look at historically Black and predominantly white liberal arts institutions. Journal of College Student Development, 37, 415-424.

Zamani-Gallaher, E. M. (2004). Proprietary schools: Beyond the issue of profit. New Directions for Institutional Research, 124, 63-79

Zhai, L., \& Monzon, R. (2001, November). Community college student retention: Student characteristics and withdrawal reasons. Paper presented at the Annual Meeting of the California Association for Institutional Research. 26th Annual Meeting, Sacramento, California.

Zurita, Martha. (2004). Stopping out and persisting: Experiences of Latino undergraduates. Journal of college student Retention, 6, 301-324. 


\section{COLLEGE GRADUATION OPINION SURVEY}

As you know, students enroll in college for many reasons. Many students eventually graduate from college while others do not. This survey is part of an investigation to discover some of the reasons why students enroll and then drop out from college. Specifically, we are interested in your personal opinions regarding graduating from college. By graduating from college, we mean being admitted, attending classes and completing all program and degree requirements. Please read each question carefully and answer it to the best of your ability. There are no correct or incorrect responses; we are merely interested in your personal point of view.

Please enter the date and $\mathrm{D} \#$ in the designated space above. Your D\# is needed for a possible follow-up survey. However, all responses to this survey are completely confidential. The instructor of this course has nothing to do with this study and will not see your responses. All identifying information (your D \#) will be removed from this questionnaire and destroyed as soon as all data has been collected. Please be assured that the information you provide in this study will have no effect on your grade or your enrollment status.

THANK YOU FOR YOUR PARTICIPATION IN THIS SURVEY! 


\section{Instructions}

The questions in this survey make use of rating scales with 7 places - please cross out the box that best describes your opinion. For example, if you were asked to rate "the weather in South Florida" on such a scale, the question would look like this:

The weather in South Florida is:

\begin{tabular}{|c|c|c|c|c|c|c|}
\hline $\begin{array}{c}\text { Extremely } \\
\text { Good }\end{array}$ & $\begin{array}{c}\text { Quite } \\
\text { Good }\end{array}$ & $\begin{array}{c}\text { Slightly } \\
\text { Good }\end{array}$ & $\begin{array}{c}\text { Neither } \\
\text { good or } \\
\text { bad }\end{array}$ & $\begin{array}{c}\text { Slightly } \\
\text { bad }\end{array}$ & $\begin{array}{c}\text { Quite } \\
\text { bad }\end{array}$ & $\begin{array}{c}\text { Extremely } \\
\text { bad }\end{array}$ \\
\hline
\end{tabular}

If you think the weather in South Florida is extremely good, then you would cross out the first box, as follows:

\begin{tabular}{|c|c|c|c|c|c|c|}
\hline $\begin{array}{c}\text { Extremely } \\
\text { Good }\end{array}$ & $\begin{array}{c}\text { Quite } \\
\text { Good }\end{array}$ & $\begin{array}{c}\text { Slightly } \\
\text { Good }\end{array}$ & $\begin{array}{c}\text { Neither } \\
\text { good or } \\
\text { bad }\end{array}$ & $\begin{array}{c}\text { Slightly } \\
\text { bad }\end{array}$ & $\begin{array}{c}\text { Quite } \\
\text { bad }\end{array}$ & $\begin{array}{c}\text { Extremely } \\
\text { bad }\end{array}$ \\
\hline
\end{tabular}

If you think the weather in South Florida is quite bad, then you would cross out the sixth box, as follows:

\begin{tabular}{|c|c|c|c|c|c|c|}
\hline $\begin{array}{c}\text { Extremely } \\
\text { Good }\end{array}$ & $\begin{array}{c}\text { Quite } \\
\text { Good }\end{array}$ & $\begin{array}{c}\text { Slightly } \\
\text { Good }\end{array}$ & $\begin{array}{c}\text { Neither } \\
\text { good or } \\
\text { bad }\end{array}$ & $\begin{array}{c}\text { Slightly } \\
\text { bad }\end{array}$ & $\begin{array}{c}\text { Quite } \\
\text { bad }\end{array}$ & $\begin{array}{c}\text { Extremely } \\
\text { bad }\end{array}$ \\
\hline
\end{tabular}

If you think the weather in South Florida is slightly good, then you would cross out the third box, as follows:

\begin{tabular}{|c|c|c|c|c|c|c|}
\hline $\begin{array}{c}\text { Extremely } \\
\text { Good }\end{array}$ & $\begin{array}{c}\text { Quite } \\
\text { Good }\end{array}$ & $\begin{array}{c}\text { Slightly } \\
\text { Good }\end{array}$ & $\begin{array}{c}\text { Neither } \\
\text { good or } \\
\text { bad }\end{array}$ & $\begin{array}{c}\text { Slightly } \\
\text { bad }\end{array}$ & $\begin{array}{c}\text { Quite } \\
\text { bad }\end{array}$ & $\begin{array}{c}\text { Extremely } \\
\text { bad }\end{array}$ \\
\hline
\end{tabular}

If you think the weather in South Florida is neither good nor bad, then you would cross out the fourth box, as follows :

\begin{tabular}{|c|c|c|c|c|c|c|}
\hline $\begin{array}{c}\text { Extremely } \\
\text { Good }\end{array}$ & $\begin{array}{c}\text { Quite } \\
\text { Good }\end{array}$ & $\begin{array}{c}\text { Slightly } \\
\text { Good }\end{array}$ & $\begin{array}{c}\text { Neither } \\
\text { good or } \\
\text { bad }\end{array}$ & $\begin{array}{c}\text { Slightly } \\
\text { bad }\end{array}$ & $\begin{array}{c}\text { Quite } \\
\text { bad }\end{array}$ & $\begin{array}{c}\text { Extremely } \\
\text { bad }\end{array}$ \\
\hline
\end{tabular}




\section{In making your ratings, please remember the following}

points :

- Be sure to answer all items - do not omit any - Do not cross out more than one box for any question

Please answer each of the following questions by circling the number that best describes your opinion. Some of the questions may appear to be similar, but they do address somewhat different issues. Please read each question carefully.

- For me to gain a better understanding of what is required to graduate from college is

\begin{tabular}{|c|c|c|c|c|c|c|}
\hline $\begin{array}{c}\text { Extremely } \\
\text { Good }\end{array}$ & $\begin{array}{c}\text { Quite } \\
\text { Good }\end{array}$ & $\begin{array}{c}\text { Slightly } \\
\text { Good }\end{array}$ & $\begin{array}{c}\text { Neither } \\
\text { good or } \\
\text { bad }\end{array}$ & $\begin{array}{c}\text { Slightly } \\
\text { bad }\end{array}$ & $\begin{array}{c}\text { Quite } \\
\text { bad }\end{array}$ & $\begin{array}{c}\text { Extremely } \\
\text { bad }\end{array}$ \\
\hline
\end{tabular}

- For me to do well and complete my college degree is

\begin{tabular}{|c|c|c|c|c|c|c|}
\hline $\begin{array}{c}\text { Extremely } \\
\text { Good }\end{array}$ & $\begin{array}{c}\text { Quite } \\
\text { Good }\end{array}$ & $\begin{array}{c}\text { Slightly } \\
\text { Good }\end{array}$ & $\begin{array}{c}\text { Neither } \\
\text { good or } \\
\text { bad }\end{array}$ & $\begin{array}{c}\text { Slightly } \\
\text { bad }\end{array}$ & $\begin{array}{c}\text { Quite } \\
\text { bad }\end{array}$ & $\begin{array}{c}\text { Extremely } \\
\text { bad }\end{array}$ \\
\hline
\end{tabular}

- For me to have an opportunity to interact with the instructor and other students in this class is

\begin{tabular}{|c|c|c|c|c|c|c|}
\hline $\begin{array}{c}\text { Extremely } \\
\text { Good }\end{array}$ & $\begin{array}{c}\text { Quite } \\
\text { Good }\end{array}$ & $\begin{array}{c}\text { Slightly } \\
\text { Good }\end{array}$ & $\begin{array}{c}\text { Neither } \\
\text { good or } \\
\text { bad }\end{array}$ & $\begin{array}{c}\text { Slightly } \\
\text { bad }\end{array}$ & $\begin{array}{c}\text { Quite } \\
\text { bad }\end{array}$ & $\begin{array}{c}\text { Extremely } \\
\text { bad }\end{array}$ \\
\hline
\end{tabular}

- For me to graduate and get a good job is

\begin{tabular}{|c|c|c|c|c|c|c|}
\hline $\begin{array}{c}\text { Extremely } \\
\text { Good }\end{array}$ & $\begin{array}{c}\text { Quite } \\
\text { Good }\end{array}$ & $\begin{array}{c}\text { Slightly } \\
\text { Good }\end{array}$ & $\begin{array}{c}\text { Neither } \\
\text { good or } \\
\text { bad }\end{array}$ & $\begin{array}{c}\text { Slightly } \\
\text { bad }\end{array}$ & $\begin{array}{c}\text { Quite } \\
\text { bad }\end{array}$ & $\begin{array}{c}\text { Extremely } \\
\text { bad }\end{array}$ \\
\hline
\end{tabular}

- For me to keep up with my studies in this class is

\begin{tabular}{|c|c|c|c|c|c|c|}
\hline $\begin{array}{c}\text { Extremely } \\
\text { Good }\end{array}$ & $\begin{array}{c}\text { Quite } \\
\text { Good }\end{array}$ & $\begin{array}{c}\text { Slightly } \\
\text { Good }\end{array}$ & $\begin{array}{c}\text { Neither } \\
\text { good or } \\
\text { bad }\end{array}$ & $\begin{array}{c}\text { Slightly } \\
\text { bad }\end{array}$ & $\begin{array}{c}\text { Quite } \\
\text { bad }\end{array}$ & $\begin{array}{c}\text { Extremely } \\
\text { bad }\end{array}$ \\
\hline
\end{tabular}


- For me to develop good study habits, self-discipline, and a feeling of self-satisfaction is

\begin{tabular}{|c|c|c|c|c|c|c|}
\hline $\begin{array}{c}\text { Extremely } \\
\text { Good }\end{array}$ & $\begin{array}{c}\text { Quite } \\
\text { Good }\end{array}$ & $\begin{array}{c}\text { Slightly } \\
\text { Good }\end{array}$ & $\begin{array}{c}\text { Neither } \\
\text { good or } \\
\text { bad }\end{array}$ & $\begin{array}{c}\text { Slightly } \\
\text { bad }\end{array}$ & $\begin{array}{c}\text { Quite } \\
\text { bad }\end{array}$ & $\begin{array}{c}\text { Extremely } \\
\text { bad }\end{array}$ \\
\hline
\end{tabular}

- Getting my money's worth while I am in school is

\begin{tabular}{|c|c|c|c|c|c|c|}
\hline $\begin{array}{c}\text { Extremely } \\
\text { Good }\end{array}$ & $\begin{array}{c}\text { Quite } \\
\text { Good }\end{array}$ & $\begin{array}{c}\text { Slightly } \\
\text { Good }\end{array}$ & $\begin{array}{c}\text { Neither } \\
\text { good or } \\
\text { bad }\end{array}$ & $\begin{array}{c}\text { Slightly } \\
\text { bad }\end{array}$ & $\begin{array}{c}\text { Quite } \\
\text { bad }\end{array}$ & $\begin{array}{c}\text { Extremely } \\
\text { bad }\end{array}$ \\
\hline
\end{tabular}

- For me to graduate from college is

\begin{tabular}{|c|c|c|c|c|c|c|}
\hline $\begin{array}{c}\text { Extremely } \\
\text { positive }\end{array}$ & $\begin{array}{c}\text { Quite } \\
\text { positive }\end{array}$ & $\begin{array}{c}\text { Slightly } \\
\text { positive }\end{array}$ & $\begin{array}{c}\text { Neither } \\
\text { positive } \\
\text { or } \\
\text { negative }\end{array}$ & $\begin{array}{c}\text { Slightly } \\
\text { negative }\end{array}$ & $\begin{array}{c}\text { Quite } \\
\text { negative }\end{array}$ & $\begin{array}{c}\text { Extremely } \\
\text { negative }\end{array}$ \\
\hline
\end{tabular}

- Most people who are important to me think that graduating from college is

\begin{tabular}{|c|c|c|c|c|c|c|}
\hline $\begin{array}{c}\text { Extremely } \\
\text { Good }\end{array}$ & $\begin{array}{c}\text { Quite } \\
\text { Good }\end{array}$ & $\begin{array}{c}\text { Slightly } \\
\text { Good }\end{array}$ & $\begin{array}{c}\text { Neither } \\
\text { good or } \\
\text { bad }\end{array}$ & $\begin{array}{c}\text { Slightly } \\
\text { bad }\end{array}$ & $\begin{array}{c}\text { Quite } \\
\text { bad }\end{array}$ & $\begin{array}{c}\text { Extremely } \\
\text { bad }\end{array}$ \\
\hline
\end{tabular}

- Whether or not I graduate from school is completely up to me

\begin{tabular}{|c|c|c|c|c|c|c|}
\hline $\begin{array}{c}\text { Extremely } \\
\text { True }\end{array}$ & $\begin{array}{c}\text { Quite } \\
\text { True }\end{array}$ & $\begin{array}{c}\text { Slightly } \\
\text { True }\end{array}$ & $\begin{array}{c}\text { Neither } \\
\text { true or } \\
\text { false }\end{array}$ & $\begin{array}{c}\text { Slightly } \\
\text { false }\end{array}$ & $\begin{array}{c}\text { Quite } \\
\text { false }\end{array}$ & $\begin{array}{c}\text { Extremely } \\
\text { false }\end{array}$ \\
\hline
\end{tabular}

- I am confident that if I want to I can graduate from college

\begin{tabular}{|c|c|c|c|c|c|c|}
\hline $\begin{array}{c}\text { Extremely } \\
\text { True }\end{array}$ & $\begin{array}{c}\text { Quite } \\
\text { True }\end{array}$ & $\begin{array}{c}\text { Slightly } \\
\text { True }\end{array}$ & $\begin{array}{c}\text { Neither } \\
\text { true or } \\
\text { false }\end{array}$ & $\begin{array}{c}\text { Slightly } \\
\text { false }\end{array}$ & $\begin{array}{c}\text { Quite } \\
\text { false }\end{array}$ & $\begin{array}{c}\text { Extremely } \\
\text { false }\end{array}$ \\
\hline
\end{tabular}

- It is expected of me that I graduate from college

\begin{tabular}{|c|c|c|c|c|c|c|}
\hline $\begin{array}{c}\text { Extremely } \\
\text { True }\end{array}$ & $\begin{array}{c}\text { Quite } \\
\text { True }\end{array}$ & $\begin{array}{c}\text { Slightly } \\
\text { True }\end{array}$ & $\begin{array}{c}\text { Neither } \\
\text { true or } \\
\text { false }\end{array}$ & $\begin{array}{c}\text { Slightly } \\
\text { false }\end{array}$ & $\begin{array}{c}\text { Quite } \\
\text { false }\end{array}$ & $\begin{array}{c}\text { Extremely } \\
\text { false }\end{array}$ \\
\hline
\end{tabular}


- I will make an effort to graduate from college

\begin{tabular}{|c|c|c|c|c|c|c|}
\hline $\begin{array}{c}\text { Extremely } \\
\text { True }\end{array}$ & $\begin{array}{c}\text { Quite } \\
\text { True }\end{array}$ & $\begin{array}{c}\text { Slightly } \\
\text { True }\end{array}$ & $\begin{array}{c}\text { Neither } \\
\text { true or } \\
\text { false }\end{array}$ & $\begin{array}{c}\text { Slightly } \\
\text { false }\end{array}$ & $\begin{array}{c}\text { Quite } \\
\text { false }\end{array}$ & $\begin{array}{c}\text { Extremely } \\
\text { false }\end{array}$ \\
\hline
\end{tabular}

- For me to graduate from college is

\begin{tabular}{|c|c|c|c|c|c|c|}
\hline $\begin{array}{c}\text { Extremely } \\
\text { Good }\end{array}$ & $\begin{array}{c}\text { Quite } \\
\text { Good }\end{array}$ & $\begin{array}{c}\text { Slightly } \\
\text { Good }\end{array}$ & $\begin{array}{c}\text { Neither } \\
\text { good or } \\
\text { bad }\end{array}$ & $\begin{array}{c}\text { Slightly } \\
\text { bad }\end{array}$ & $\begin{array}{c}\text { Quite } \\
\text { bad }\end{array}$ & $\begin{array}{c}\text { Extremely } \\
\text { bad }\end{array}$ \\
\hline
\end{tabular}

- Most people whose opinions I value approve my going to college

\begin{tabular}{|c|c|c|c|c|c|c|}
\hline $\begin{array}{c}\text { Extremely } \\
\text { True }\end{array}$ & $\begin{array}{c}\text { Quite } \\
\text { True }\end{array}$ & $\begin{array}{c}\text { Slightly } \\
\text { True }\end{array}$ & $\begin{array}{c}\text { Neither } \\
\text { true or } \\
\text { false }\end{array}$ & $\begin{array}{c}\text { Slightly } \\
\text { false }\end{array}$ & $\begin{array}{c}\text { Quite } \\
\text { false }\end{array}$ & $\begin{array}{c}\text { Extremely } \\
\text { false }\end{array}$ \\
\hline
\end{tabular}

- For me to attend college is

\begin{tabular}{|c|c|c|c|c|c|c|}
\hline $\begin{array}{c}\text { Extremely } \\
\text { Good }\end{array}$ & $\begin{array}{c}\text { Quite } \\
\text { Good }\end{array}$ & $\begin{array}{c}\text { Slightly } \\
\text { Good }\end{array}$ & $\begin{array}{c}\text { Neither } \\
\text { good or } \\
\text { bad }\end{array}$ & $\begin{array}{c}\text { Slightly } \\
\text { bad }\end{array}$ & $\begin{array}{c}\text { Quite } \\
\text { bad }\end{array}$ & $\begin{array}{c}\text { Extremely } \\
\text { bad }\end{array}$ \\
\hline
\end{tabular}

- Generally speaking, how much do you care what your instructors think you should do?

\begin{tabular}{|l|c|c|c|c|c|c|}
\hline $\begin{array}{c}\text { Extremely } \\
\text { Important }\end{array}$ & $\begin{array}{c}\text { Quite } \\
\text { Important }\end{array}$ & $\begin{array}{c}\text { Slightly } \\
\text { Important }\end{array}$ & $\begin{array}{c}\text { Neither } \\
\text { important } \\
\text { or } \\
\text { unimportant }\end{array}$ & $\begin{array}{c}\text { Slightly } \\
\text { unimportant }\end{array}$ & $\begin{array}{c}\text { Quite } \\
\text { unimportant }\end{array}$ & $\begin{array}{c}\text { Extremely } \\
\text { unimportant }\end{array}$ \\
\hline
\end{tabular}

- Generally speaking, how much do you care what your parents thing you should do?

\begin{tabular}{|l|c|c|c|c|c|c|}
\hline $\begin{array}{c}\text { Extremely } \\
\text { Important }\end{array}$ & $\begin{array}{c}\text { Quite } \\
\text { Important }\end{array}$ & $\begin{array}{c}\text { Slightly } \\
\text { Important }\end{array}$ & $\begin{array}{c}\text { Neither } \\
\text { important } \\
\text { or } \\
\text { unimportant }\end{array}$ & $\begin{array}{c}\text { Slightly } \\
\text { unimportant }\end{array}$ & $\begin{array}{c}\text { Quite } \\
\text { unimportant }\end{array}$ & $\begin{array}{c}\text { Extremely } \\
\text { unimportant }\end{array}$ \\
\hline
\end{tabular}

- Generally speaking, how much do you care what your close friends think you should do?

\begin{tabular}{|l|c|c|c|c|c|c|}
\hline $\begin{array}{c}\text { Extremely } \\
\text { Important }\end{array}$ & $\begin{array}{c}\text { Quite } \\
\text { Important }\end{array}$ & $\begin{array}{c}\text { Slightly } \\
\text { Important }\end{array}$ & $\begin{array}{c}\text { Neither } \\
\text { important } \\
\text { or } \\
\text { unimportant }\end{array}$ & $\begin{array}{c}\text { Slightly } \\
\text { unimportant }\end{array}$ & $\begin{array}{c}\text { Quite } \\
\text { unimportant }\end{array}$ & $\begin{array}{c}\text { Extremely } \\
\text { unimportant }\end{array}$ \\
\hline
\end{tabular}


- Generally speaking, how much do you care what your classmates think you should do?

\begin{tabular}{|l|c|c|c|c|c|}
\hline $\begin{array}{c}\text { Extremely } \\
\text { Important }\end{array}$ & $\begin{array}{c}\text { Quite } \\
\text { Important }\end{array}$ & $\begin{array}{c}\text { Slightly } \\
\text { Important }\end{array}$ & $\begin{array}{c}\text { Neither } \\
\text { important } \\
\text { or } \\
\text { unimportant }\end{array}$ & $\begin{array}{c}\text { Slightly } \\
\text { unimportant }\end{array}$ & $\begin{array}{c}\text { Quite } \\
\text { unimportant } \\
\text { unimportant }\end{array}$ \\
\hline
\end{tabular}

- How often do you encounter unanticipated events that place demands on your time?

\begin{tabular}{|c|c|c|c|c|c|c|}
\hline $\begin{array}{c}\text { Extremely } \\
\text { Often }\end{array}$ & $\begin{array}{c}\text { Quite } \\
\text { Often }\end{array}$ & $\begin{array}{c}\text { Slightly } \\
\text { Often }\end{array}$ & $\begin{array}{c}\text { Neither } \\
\text { often } \\
\text { or } \\
\text { never }\end{array}$ & Sometimes & $\begin{array}{c}\text { Hardly } \\
\text { ever }\end{array}$ & Never \\
\hline
\end{tabular}

- How often do you feel ill, tired or listless?

\begin{tabular}{|c|c|c|c|c|c|c|}
\hline $\begin{array}{c}\text { Extremely } \\
\text { Often }\end{array}$ & $\begin{array}{c}\text { Quite } \\
\text { Often }\end{array}$ & $\begin{array}{c}\text { Slightly } \\
\text { Often }\end{array}$ & $\begin{array}{c}\text { Neither } \\
\text { often } \\
\text { or } \\
\text { never }\end{array}$ & Sometimes & $\begin{array}{c}\text { Hardly } \\
\text { ever }\end{array}$ & Never \\
\hline
\end{tabular}

- How often do family obligations place unanticipated demands on your time?

\begin{tabular}{|c|c|c|c|c|c|c|}
\hline $\begin{array}{c}\text { Extremely } \\
\text { Often }\end{array}$ & $\begin{array}{c}\text { Quite } \\
\text { Often }\end{array}$ & $\begin{array}{c}\text { Slightly } \\
\text { Often }\end{array}$ & $\begin{array}{c}\text { Neither } \\
\text { often } \\
\text { or } \\
\text { never }\end{array}$ & Sometimes & $\begin{array}{c}\text { Hardly } \\
\text { ever }\end{array}$ & Never \\
\hline
\end{tabular}

- How often does work or employment place unanticipated demands on your time?

\begin{tabular}{|c|c|c|c|c|c|c|}
\hline $\begin{array}{c}\text { Extremely } \\
\text { Often }\end{array}$ & $\begin{array}{c}\text { Quite } \\
\text { Often }\end{array}$ & $\begin{array}{c}\text { Slightly } \\
\text { Often }\end{array}$ & $\begin{array}{c}\text { Neither } \\
\text { often } \\
\text { or } \\
\text { never }\end{array}$ & Sometimes & $\begin{array}{c}\text { Hardly } \\
\text { ever }\end{array}$ & Never \\
\hline
\end{tabular}

- How often do other courses place heavy demands on your time?

\begin{tabular}{|c|c|c|c|c|c|c|}
\hline $\begin{array}{c}\text { Extremely } \\
\text { Often }\end{array}$ & $\begin{array}{c}\text { Quite } \\
\text { Often }\end{array}$ & $\begin{array}{c}\text { Slightly } \\
\text { Often }\end{array}$ & $\begin{array}{c}\text { Neither } \\
\text { often } \\
\text { or } \\
\text { never }\end{array}$ & Sometimes & $\begin{array}{c}\text { Hardly } \\
\text { ever }\end{array}$ & Never \\
\hline
\end{tabular}


- The instructors for my courses think that I should graduate from college

\begin{tabular}{|c|c|c|c|c|c|c|}
\hline $\begin{array}{c}\text { Extremely } \\
\text { True }\end{array}$ & $\begin{array}{c}\text { Quite } \\
\text { True }\end{array}$ & $\begin{array}{c}\text { Slightly } \\
\text { True }\end{array}$ & $\begin{array}{c}\text { Neither } \\
\text { true or } \\
\text { false }\end{array}$ & $\begin{array}{c}\text { Slightly } \\
\text { false }\end{array}$ & $\begin{array}{c}\text { Quite } \\
\text { false }\end{array}$ & $\begin{array}{c}\text { Extremely } \\
\text { false }\end{array}$ \\
\hline
\end{tabular}

- My parents think that I should graduate from college

\begin{tabular}{|c|c|c|c|c|c|c|}
\hline $\begin{array}{c}\text { Extremely } \\
\text { True }\end{array}$ & $\begin{array}{c}\text { Quite } \\
\text { True }\end{array}$ & $\begin{array}{c}\text { Slightly } \\
\text { True }\end{array}$ & $\begin{array}{c}\text { Neither } \\
\text { true or } \\
\text { false }\end{array}$ & $\begin{array}{c}\text { Slightly } \\
\text { false }\end{array}$ & $\begin{array}{c}\text { Quite } \\
\text { false }\end{array}$ & $\begin{array}{c}\text { Extremely } \\
\text { false }\end{array}$ \\
\hline
\end{tabular}

- My close friends think that I should graduate from college

\begin{tabular}{|c|c|c|c|c|c|c|}
\hline $\begin{array}{c}\text { Extremely } \\
\text { True }\end{array}$ & $\begin{array}{c}\text { Quite } \\
\text { True }\end{array}$ & $\begin{array}{c}\text { Slightly } \\
\text { True }\end{array}$ & $\begin{array}{c}\text { Neither } \\
\text { true or } \\
\text { false }\end{array}$ & $\begin{array}{c}\text { Slightly } \\
\text { false }\end{array}$ & $\begin{array}{c}\text { Quite } \\
\text { false }\end{array}$ & $\begin{array}{c}\text { Extremely } \\
\text { false }\end{array}$ \\
\hline
\end{tabular}

- My classmates think that I should graduate from college

\begin{tabular}{|c|c|c|c|c|c|c|}
\hline $\begin{array}{c}\text { Extremely } \\
\text { True }\end{array}$ & $\begin{array}{c}\text { Quite } \\
\text { True }\end{array}$ & $\begin{array}{c}\text { Slightly } \\
\text { True }\end{array}$ & $\begin{array}{c}\text { Neither } \\
\text { true or } \\
\text { false }\end{array}$ & $\begin{array}{c}\text { Slightly } \\
\text { false }\end{array}$ & $\begin{array}{c}\text { Quite } \\
\text { false }\end{array}$ & $\begin{array}{c}\text { Extremely } \\
\text { false }\end{array}$ \\
\hline
\end{tabular}




\section{SEMI-STRUCTURED INTERVIEW GUIDE}

Thank you for agreeing to participate in this interview about your experiences in college. The purpose of this interview is to learn what obstacles and supports you encountered during your first session of study at DeVry. I will begin with some general questions about you and then we will start talking about your college experiences.

- Do you have any questions before we begin?

- First, I am going to ask you some questions about your background:

- Tell me about your family?

- How would you describe your ethnic heritage?

- What program were you (are you) enrolled in?

○ How old are you?

o Is this the first time you have attended a college or University?

- Now, I'd like to ask you some questions about college:

- Tell me about your college experience at DeVry?

o What was DeVry like?

o What was your first session like?

- Tell me about your classes, your teachers, your coursework, etc.

- Let's talk a little about how you decided to attend college: 
- Tell me about your decision to attend college.

o What did you know about college prior to attending?

- How long have you been considering attending college?

- What factors led you to think about college?

- Which individuals influenced your decision about attending college?

o What were your goals when you decided to attend college?

o Why did you choose DeVry?

- Everybody has concerns when they enter college:

- Tell me how you felt about your academic skills?

- Tell me how you handled work and school at the same time?

- Tell me about your plans to finance your education?

- How do you feel about your decision to enroll in college?

○ What were you feeling when you started school?

- Additional probes based on CSI report.

- Supports encountered during college:

○ Who helped you during your first session?

○ Why were they helpful?

- What programs have helped you during your first session?

○ Why was it helpful?

o Did you seek out support? 
o What helped you the most during your first session?

o What helped you the least during your first session?

- Barriers encountered during college:

o What barriers have you encountered during your first session?

- Were you able to overcome this barrier?

- How?

- What would have helped you overcome this barrier?

- Did this barrier influence your decision to continue?

- What you think has been the most important things that have kept you motivated to continue college?

- [Ask this question if the participant has stopped attending] What are the reasons you think made you stop attending college?

- Do you think you will return to college at a later point?

- What things would you recommend that a student do when deciding about whether to attend college?

- What things would you recommend that a student do that would help them stay in school? 
- Is there anything else you think I should know about your college experience?

- Do you have any questions before we end?

Thank you very much for participating in this study. 
Consent to Participate in a Research study

Factors That Differentiate Persistence Beyond the First Session at a For-Profit University.

You are being asked to participate in a research study. The investigator of this study is Jesus Fernandez, a student at FIU. The study will include about 6 people who are enrolled at DeVry University. Your participation will require 1 to 2 hours of your time.

The purpose of this research study is to discover what factors encourage or hinder students to continue their studies at universities like DeVry. If you decide to be a part of this study you will be asked to participate in an interview with the principal investigator. The investigator will ask you about your experiences during your first session at DeVry.

We do not expect any harm to you be being in the study. You may skip any question that you do not wish to answer. If you get upset or feel discomfort during the interview, you may ask to take a break. There is no cost or payment to you as a subject. You will not directly benefit from being in the study, however, your participation will assist the researcher in gathering knowledge in this area of study.

Your answers will be confidential and will be identified by a random code not your name or D\#. Your data will be compared to the data of other participants and will only be viewed by the primary investigator. The research results will be presented as a group. You may ask questions about the study at any time. You may withdraw your consent and discontinue participation in this research project at any time with no negative consequences. All information pertaining to this study and your participation will be kept in a locked file drawer.

You have the right to ask questions and to have them answered to your satisfaction. If you desire further information about this research, you may contact Jesus Fernandez at (954) 438-5670. If you feel you were mistreated or would like to talk with someone about being a 
volunteer participant in this study you may contact Marylou Lasater, the Director of Institutional Research at DeVry University at (630) 953-3615. Your signature below

indicates that all questions have been answered to your

liking. You are aware of your rights and you would like to be in the study.

\section{Signature of Participant $\quad$ Printed Name Date}

I have explained the research procedure, subject rights and answered questions asked by the participant. I have offered him/her a copy of this informed consent form.

Signature of Witness

Date 
VITA

JESÚS FERNÁNDEZ

Born, Havana, Cuba

1979

B.A., Psychology (with honors)

Northwestern University

Evanston, Illinois

$1981-1984$

Human Resource Generalist

Amerifirst Federal Savings Bank

Miami, Florida

$1984-1986$

Branch Manager

Chase Federal Savings Bank

Miami, Florida

1988

M.B.A

Barry University

Miami Shores, Florida

$1986-1989$

$1989-1999$

$1999-2002$

$2002-2008$

Regional Vice President, Administration

Ensign Bank

Miami, Florida

Senior Vice President, Administration Eagle Bank

Miami, Florida

Founding School Director

School of Business/CIS

Miami Dade College

Miami, Florida

Founding Dean of Academic Affairs

DeVry University - South Florida

Miramar, Florida

2008

National Dean of Academic Quality DeVry University

Downers Grove, Illinois

$2008-2010$

National Dean of Curriculum

DeVry University

Downers Grove, Illinois 


\section{0 - Present Associate Provost - Curriculum DeVry University \\ Downers Grove, Illinois}

